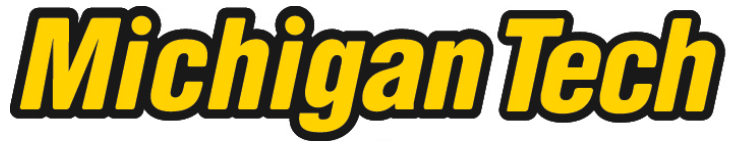 \\ Michigan Technological University Create the Future Digital Commons @ Michigan Tech
}

Dissertations, Master's Theses and Master's Reports - Open

Dissertations, Master's Theses and Master's

Reports

2014

\section{MODELING AND EXPERIMENTAL SETUP OF AN HCCI ENGINE}

Vishal Shailesh Thakkar

Michigan Technological University

Follow this and additional works at: https://digitalcommons.mtu.edu/etds

Part of the Engineering Commons

Copyright 2014 Vishal Shailesh Thakkar

\section{Recommended Citation}

Thakkar, Vishal Shailesh, "MODELING AND EXPERIMENTAL SETUP OF AN HCCI ENGINE", Master's Thesis, Michigan Technological University, 2014.

https://doi.org/10.37099/mtu.dc.etds/815

Follow this and additional works at: https://digitalcommons.mtu.edu/etds

Part of the Engineering Commons 
Vishal Shailesh Thakkar

\begin{abstract}
A THESIS
Submitted in partial fulfillment of the requirements for the degree of MASTER OF SCIENCE

In Mechanical Engineering
\end{abstract}

MICHIGAN TECHNOLOGICAL UNIVERSITY

2014

(C) 2014 Vishal Shailesh Thakkar 
This thesis, "Modeling and Experimental Setup of an HCCI Engine," is hereby approved in partial fulfillment of the requirements for the Degree of MASTER OF SCIENCE in Mechanical Engineering.

Department of Mechanical Engineering-Engineering Mechanics

Thesis Advisor: Dr. Mahdi Shahbakhti

Committee Member: Dr. Scott Miers

Committee Member: Dr. Seyyedmohsen Azizi

Department Chair: Dr. William Predebon 
To my brother Dhaval. 


\section{Contents}

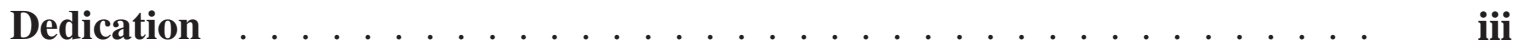

List of Figures . . . . . . . . . . . . . . . . . . . viii

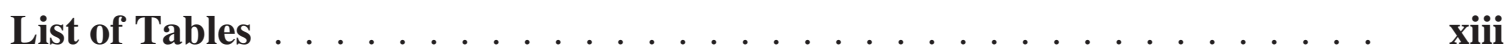

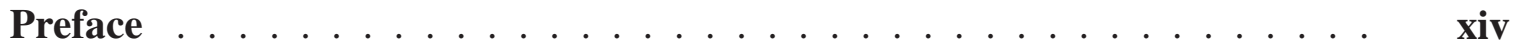

Ackowledgment ......................

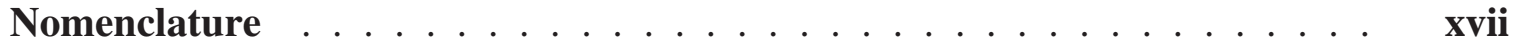

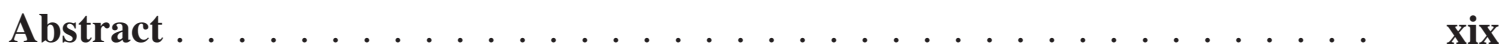

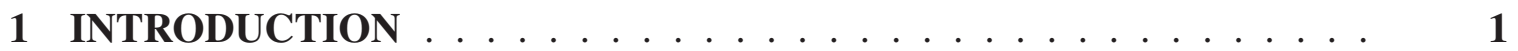

1.1 Background .......................... 4

1.1.1 HCCI History . . . . . . . . . . . . . . . . 4

1.1.2 Operating Principles ................ 6

1.1.3 Pros and Cons . . . . . . . . . . . . . . . 8

1.2 Research Scope and Thesis Organization . . . . . . . . . . . . . 10 


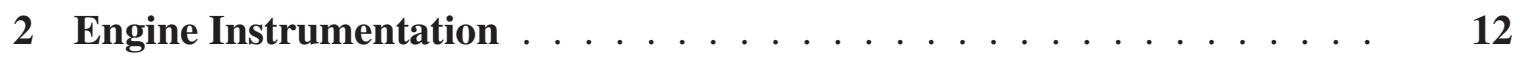

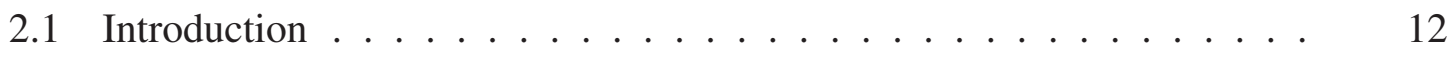

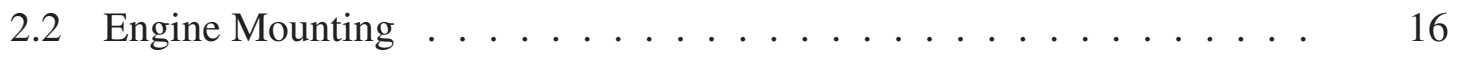

2.2.1 Interface Panels . . . . . . . . . . . . . . . . . . . . . . 19

2.2.2 Coolant and Water Lines $\ldots \ldots \ldots \ldots$

2.2 .3 ECU Mount . . . . . . . . . . . . . . . . . . . . . 24

2.2 .4 Intake Air Circuit . . . . . . . . . . . . . . . . 26

2.2.5 Exhaust Gas Recirculation Circuit . . . . . . . . . . . . 29

2.3 Sensors \& Actuators . . . . . . . . . . . . . . . . . . . . . 31

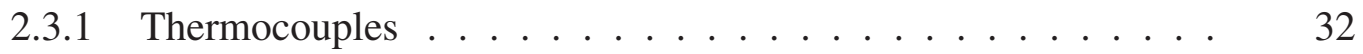

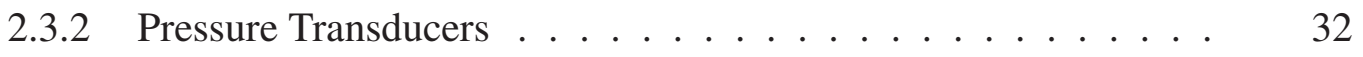

2.3.3 Shaft Encoder . . . . . . . . . . . . . . . . 36

2.3.4 Lambda Sensor . . . . . . . . . . . . . . . . . . 40

2.4 Wire Harness and OBDII Connections . . . . . . . . . . . . 41

2.5 Summary $\ldots \ldots \ldots \ldots \ldots \ldots \ldots \ldots \ldots \ldots \ldots \ldots \ldots$

3 Grey Box Modeling $\ldots \ldots \ldots \ldots \ldots \ldots \ldots \ldots$

3.1 Introduction $\ldots \ldots \ldots \ldots \ldots \ldots \ldots \ldots \ldots \ldots \ldots \ldots$

3.2 Experimental Data . . . . . . . . . . . . . . . 51

3.3 Grey-box Model Description $\ldots \ldots \ldots \ldots \ldots$

3.3.1 Architecture of Model . . . . . . . . . . . . . 56

$3.3 .2 \quad$ Physical Model . . . . . . . . . . . . . . . 57 
3.3.3 Artificial (Black-Box) Model . . . . . . . . . . . . . 58

3.4 Results and Discussion . . . . . . . . . . . . . . 62

3.4.1 ANN Structure Design . . . . . . . . . . . . . . 62

3.4.2 Combustion Phasing and Engine Load (IMEP) . . . . . . . . . 65

3.4.3 Exhaust Gas Temperature . . . . . . . . . . . . . . . 69

3.4.4 Engine-out Emissions . . . . . . . . . . . . . . 70

3.4.5 Transient Validation . . . . . . . . . . . . . . 72

3.4.6 Validation on a Different HCCI Engine (Yanmar) . . . . . . . . 74

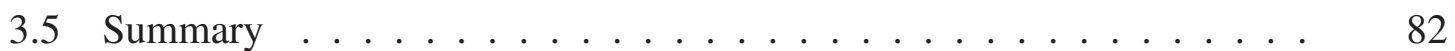

4 Conclusion .......................... 84

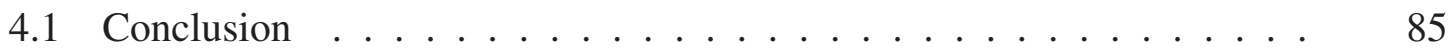

4.1.1 Experimental setup of an HCCI engine . . . . . . . . . . . 85

4.1.2 Grey box modelling of an HCCI engine . . . . . . . . . . . 86

4.2 Future Work . . . . . . . . . . . . . . . . . . . 87

References ............................... 90

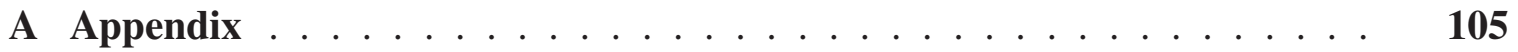

B M.Sc. Publications . . . . . . . . . . . . . . . . . . 109

B.1 Peer Reviewed Papers . . . . . . . . . . . . . . . . . . . . . . 109

B.2 Permission from Co-author . . . . . . . . . . . . . 110 
C Data Sheets ............................. 112

D Thesis Files Summary . . . . . . . . . . . . . . . . . . . . . . . 128

E Fair Use . . . . . . . . . . . . . . . . . . . . . . . . . . . . 134 


\section{List of Figures}

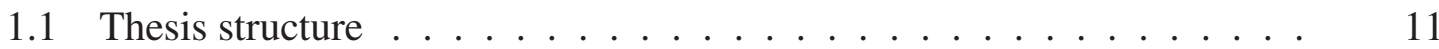

2.1 3D Engine mount (photo by author) $\ldots \ldots \ldots \ldots \ldots$

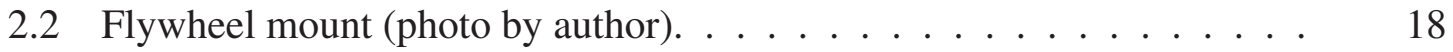

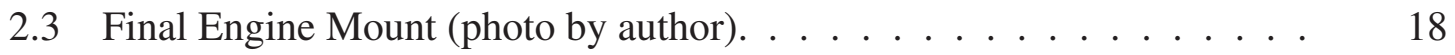

(a) Engine Front Mount $\ldots \ldots \ldots \ldots \ldots \ldots$

(b) Engine Rear Mount . . . . . . . . . . . . . . . . . . 18

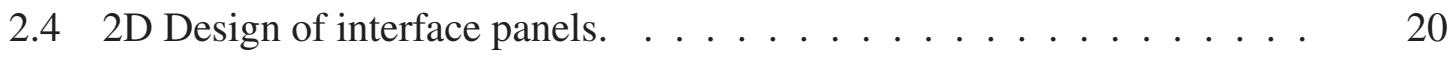

(a) Interface panel for fuel and water lines 2D design . . . . . . 20

(b) Interface panel electrical connections 2D design . . . . . . 20

2.5 Manufactured interface panels (photo by author). . . . . . . . . 21

2.6 Coolant and water lines connections (photo by author). . . . . . . 23

2.7 ECU mount (photo by author) $\ldots \ldots \ldots \ldots \ldots$

2.8 3D design for post turbo intake air circuit (photo by author) . . . . . 27

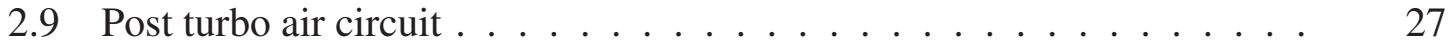

2.10 Compressed intake air cicuit from intercooler outlet to the air-heater inlet 28

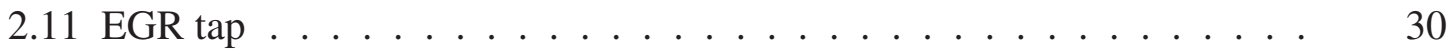


2.12 EGR cooler . . . . . . . . . . . . . . . 30

2.13 Sensors mount and overview of lab setup . . . . . . . . . . . 31

2.14 Pressure transducer and thermocouple on the intake manifold . . . . . 33

2.15 In-cylinder pressure transducer voltage reading . . . . . . . . . . 34

2.16 Encoder mount exploded 3D design . . . . . . . . . . . . 37

2.17 Encoder mount compete 3D design . . . . . . . . . . . . . 37

2.18 Manufactured encoder mount . . . . . . . . . . . . . . 38

2.19 Crank angle reading . . . . . . . . . . . . . . 39

2.20 Lambda sensor mount . . . . . . . . . . . . . . . . . . . 40

2.21 OBDII wiring connector $\ldots \ldots \ldots \ldots$. . . . . . . . . 41

2.22 Thermocouple wiring . . . . . . . . . . . . . . . 42

2.23 Final engine mount . . . . . . . . . . . . . . . 43

2.24 Final engine dyno setup . . . . . . . . . . . . . . . . 44

3.1 Background of HCCI engine control modeling in literature [1,2]. . . . 49

3.2 Operating range for 208 experimental HCCI data points used in this study $[1,2]$ (Ricardo engine) . . . . . . . . . . . . . . . 53

3.3 Range of engine combustion phasing (CA50), load (IMEP), and exhaust gas temperature $\left(T_{\text {exh }}\right)$ for the experimental data points shown in Figure 3.2 $[1,2]$. (Ricardo engine) . . . . . . . . . . . . . . . 54

3.4 Range of engine $\mathrm{CO}$, THC, and NOx exhaust gas concentrations for the experimental data points shown in Figure 3.2 [1,2]. (Ricardo engine) . 
3.5 Architecture of the grey-box HCCI model $[1,2] . \ldots$. . . . . . . . 57

3.6 Feedfoward Artificial Neural Networks (ANN) for CA50 and IMEP used

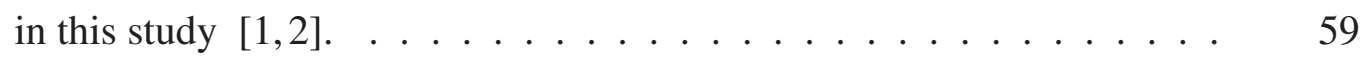

3.7 Feedfoward Artificial Neural Networks (ANN) for $T_{\text {exh }}$ used in this study

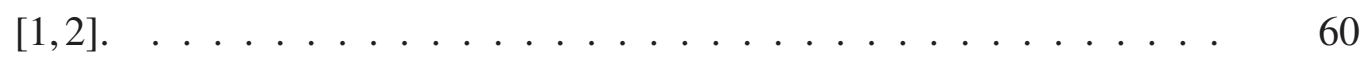

3.8 Feedfoward Artificial Neural Networks (ANN) for emissions used in this

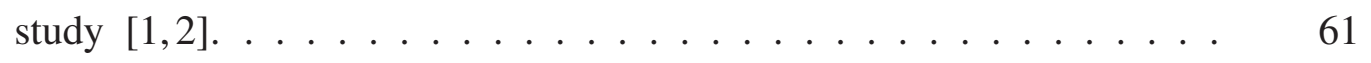

3.9 Training metrics for the CA50-IMEP ANN model. Normalized MSE in the $\mathrm{y}$-axis is the average of normalized MSE for CA50 and IMEP [1,2]. . .

3.10 Training MSE over iteration history for the CA50-IMEP ANN model. Normalized MSE in the y-axis is the average of normalized MSE for CA50 and IMEP $[1,2] . \ldots \ldots \ldots \ldots \ldots \ldots$

3.11 Prediction of CA50 for Ricardo engine: (a) training, (b) validation data

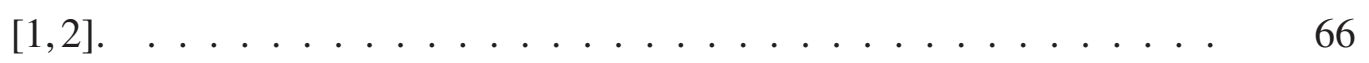

3.12 Prediction of IMEP for Ricardo engine: (a) training, (b) validation data $[1,2] \ldots \ldots \ldots \ldots \ldots \ldots \ldots \ldots \ldots \ldots \ldots \ldots \ldots \ldots \ldots \ldots \ldots$

3.13 Prediction of $T_{\text {exh }}$ (exhaust gas temperature) for Ricardo engine: (a) training, (b) validation data $[1,2] \ldots \ldots \ldots$. . . . . . . . . 69

3.14 Prediction of $\mathrm{CO}$ concentration for Ricardo engine: (a) training, (b) validation data $[1,2] \ldots \ldots \ldots \ldots \ldots \ldots$ 
3.15 Prediction of THC concentration for Ricardo engine: (a) training, (b) validation data $[1,2] \ldots \ldots \ldots \ldots \ldots$. . . . . . . . . . . . 71

3.16 Prediction of NOx concentration for Ricardo engine: (a) training, (b) validation data $[1,2] \ldots \ldots \ldots \ldots \ldots \ldots$

3.17 Validation of the CA50-IMEP, $T_{\text {exh }}$ grey-box models for transient fueling conditions in Ricardo engine $\left(P_{m}=110 \mathrm{kPa}, T_{m}=91 \mathrm{C}\right.$, External EGR = $\left.0 \%, P_{\text {exh }}=99 \mathrm{kPa}, \mathrm{N}=815 \mathrm{rpm}\right)[1,2] . \ldots \ldots \ldots$

3.18 Operating range for the HCCI experimental data from Yanmar engine [1,

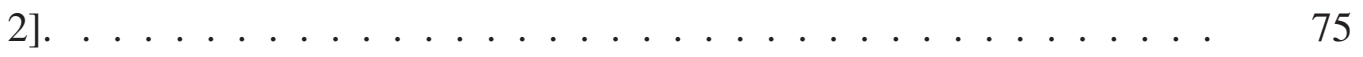

3.19 Prediction of CA50 for Yanmar engine: (a) Training, (b) Validation [1,2]. 77

3.20 Prediction of IMEP for Yanmar engine: (a) Training, (b) Validation [1,2]. 78

3.21 Prediction of $T_{\text {exh }}$ for Yanmar engine: (a) Training, (b) Validation [1,2]. 79

3.22 Prediction of CO for Yanmar engine: (a) Training, (b) Validation [1,2]. 80

3.23 Prediction of THC concentration for Yanmar engine: (a) Training, (b)

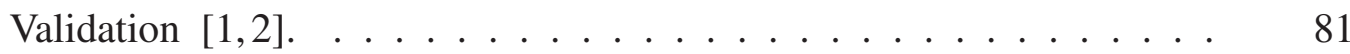

C.1 Incylinder pressure transducer data sheet . . . . . . . . . . . . 113

C.2 Incylinder pressure transducer data sheet $2 \ldots \ldots \ldots$. . . . . . 114

C.3 Technical data sheet 1 of shaft encoder . . . . . . . . . . 115

C.4 Technical data sheet 2 of shaft encoder . . . . . . . . . . . . 116

C.5 Technical data sheet 3 of shaft encoder . . . . . . . . . . . . 117

C.6 Technical data sheet 4 of shaft encoder . . . . . . . . . . . . . 118 
C.7 Technical data sheet 1 of lambda sensor . . . . . . . . . . . . . 119

C.8 Technical data sheet 2 of lambda sensor . . . . . . . . . . . . 120

C.9 Technical data sheet 3 of lambda sensor f . . . . . . . . . . 121

C.10 Technical data sheet 1 of thermocouples . . . . . . . . . . 122

C.11 Technical data sheet 2 of thermocouples . . . . . . . . . 123

C.12 Technical data sheet 3 of thermocouples . . . . . . . . . . 124

C.13 Technical data sheet 4 of thermocouples . . . . . . . . . 125

C.14 Technical data sheet 1 of pressure transducer . . . . . . . . . 126

C.15 Technical data sheet 2 of pressure transducer . . . . . . . . . 127 


\section{List of Tables}

2.1 Specifications of GM 2.0L Turbo I4 GEN I Ecotec LHU Engine . . . . 14

2.2 Auxiliary parts added to the engine. . . . . . . . . . 15

2.3 Modifications required on the engine. . . . . . . . . . 15

3.1 Specification of Ricardo single cylinder engine. . . . . . . . . . . . 52

3.2 Comparison of average accuracy of the clear-box, black-box, and the grey-box models for all fuels for Ricardo engine $[1,2] . \ldots$. . . . . . 68

3.3 Prediction accuracy metrics for transient validation of the CA50-IMEP and $T_{\text {exh }}$ grey-box models for Ricardo engine $[1,2] . \ldots \ldots$. . . . . . 72

3.4 Specifications of single cylinder Yanmar L70AE engine $[1,2] . \ldots 74$

3.5 Comparison of average accuracy of the clear-box, black-box, and the grey-box models for Yanmar engine $[1,2] . \ldots \ldots$. . . . . . 76

D.1 Data files $(. x l s x) \ldots \ldots \ldots \ldots$

D.2 Matlab code $(. \mathrm{m}) \ldots \ldots \ldots \ldots \ldots$

D.3 Matlab figures $(. f i g) \ldots \ldots \ldots \ldots \ldots \ldots \ldots$

D.4 Data sheets . . . . . . . . . . . . . . . . 132

D.5 Images and Visio drawing . . . . . . . . . . . . 133 


\section{Preface}

Chapter 2. Figure 2.13 was developed with discussion and modification suggested by the EML lab setup team consisting of Dr. Mahdi Shahbakhti, Paul Dice, Deepak Kothari, Hrishikesh Saigoankar and others.

Chapter 3. A version of this material has been accepted to be published as "Grey-box Modeling of HCCI Engines ", Journal of Applied Thermal Engineering, to appear in vol. 70, Issue 1, pages 397-409, Sept. 2014 by M. Bidarvatan, V. Thakkar, M. Shahbakhti, B. Bahri and A. Abdul Aziz. Mehran Bidarvatan worked on the CA50, IMEP and Texh modelling and I worked on the emissions part of the grey-box model. The data for the Ricardo engine was provided by Dr. Bob Koch and data for Yanmar engine from University of Alberta was provided by Dr. B. Bahri et al from Universiti Teknologi Malaysia. Mehran and I worked together on developing the manuscript for the paper. I contributed mainly on the emissions side. Results for Chapter 3 were also forwarded to proceedings of the 2014 American Control Conference, Portland, Oregon, USA June 4-6, 2014, ”Grey-box Modeling and Control of HCCI Engine Emissions” by Mehran Bidarvatan, Dr. Mahdi Shahbakhti and myself. The permission to use the published material in this thesis in Chapter 3 can be found in Appendix B.1. 


\section{Acknowledgment}

It is a great pleasure to take this opportunity to express my gratitude to the many people who have helped or supported this work.

I am heartily thankful to my supervisor, Dr. Mahdi Shahbakhti, whose encouragement, guidance and support from the initial to the final level enabled me to accomplish this work. He introduced me to HCCI engines and used his invaluable wealth of knowledge and time to mentor my understanding of the subject and to build up my research skills. At the same time Dr. Shahbakhti has been a wonderful counselor. He has always given me valuable advice for my future academic life and supported me during my MSc.

I would also like to thank Dr. Scott Miers; his profound knowledge and exceptional teaching skills have contributed substantially to my understanding of combustion engines. I am also grateful to the examination committee for their thorough feedbacks on the manuscript of the thesis.

I am grateful to Jermey Worm and Paul Dice for their time, work and expert guidance during the EML test lab setup.

I graciously acknowledge Hrishikesh Saigaonkar, Guangchen Xiong, Fouad Ahmed and 
Deepak Kothari for their contributions in base HCCI engine experimental setup at Michigan Technological University for this work. I am profoundly indebted to them for their time and help. Thanks are also due to technician Bill Langdon, Martin Toth and Robert W. Page for their help in fabricating various parts for the EML test lab.

Many thanks are deserved to my co-author Mehran Bidarvatan, for his excellent guidance throughout this thesis and work which significantly contributed to the quality of this thesis. I gratefully acknowledge Prof. C.R. Koch from the University of Alberta for providing the Ricardo engine experimental data used in this study and Dr. B. Bahri et al from Universiti Teknologi Malaysia who provided the data for Yanmar engine HCCI experimental setup.

I would like to thank Debra Charlesworth, Nancy Byers, Nancy Barr and James Issac who made some wonderful edits and suggestions to my thesis. Lastly, my family and friends are those whom I can not thank enough for their love, encouragement and supporting me spiritually throughout this work. 


\section{Nomenclature}

\begin{tabular}{|c|c|}
\hline$\Phi$ & Fuel Equivalence Ratio [-] \\
\hline$\dot{m}$ & Gas Flow Rate $[\mathrm{kg} / \mathrm{s}]$ \\
\hline$\theta$ & Crank Angle [CAD] \\
\hline $\mathrm{aBDC}$ & after Bottom Dead Center \\
\hline aTDC & after Top Dead Center \\
\hline $\mathrm{aBDC}$ & after Bottom Dead Center \\
\hline AFR & Air Fuel Ratio \\
\hline ANN & Artificial Neural Network \\
\hline CA50 & Crank Angle for $50 \%$ Burnt Fuel [CAD aTDC] \\
\hline CAD & Crank Angle Degree $\left[^{\circ}\right]$ \\
\hline $\mathrm{CO}$ & Carbon Monoxide Concentration [\%] \\
\hline $\mathrm{CO}_{2}$ & Carbon Dioxide Concentration [\%] \\
\hline $\mathrm{CoC}$ & Completeness of Combustion [-] \\
\hline$C_{D}$ & Discharge Coefficient [-] \\
\hline$C_{v}$ & Constant Volume Specific Heat $\left[\frac{k J}{k g \cdot K}\right]$ \\
\hline$C_{p}$ & Constant Pressure Specific Heat $\left[\frac{\mathrm{kJ}}{\mathrm{kg} \cdot \mathrm{K}}\right]$ \\
\hline$d_{v}$ & Diameter of Exhaust Valve [m] \\
\hline EGR & Exhaust Gas Recirculation [\%] \\
\hline ECU & Engine Control Unit \\
\hline IMEP & Indicated Mean Effective Pressure [bar] \\
\hline ICE & Internal Combustion \\
\hline $\mathrm{HC}$ & Hydrocarbons \\
\hline HCCI & Homogenous Charge Compression Ignition \\
\hline LHV & Lower Heating Value $[\mathrm{kJ} / \mathrm{kg}]$ \\
\hline$L_{v}$ & Axial Valve Lift $[\mathrm{m}]$ \\
\hline MIMO & Multi Input Multi Output \\
\hline MISO & Multi Input Single Output \\
\hline MSE & Mean Square Error \\
\hline $\mathrm{N}$ & Engine Speed [RPM] \\
\hline NOx & Oxides of Nitrogen Concentration [PPM] \\
\hline OBD & On-Board Diagnostic \\
\hline ON & Octane Number [-] \\
\hline $\mathrm{P}$ & Pressure $[\mathrm{kPa}]$ \\
\hline PM & Particulate Matter \\
\hline PPM & Parts Per Million \\
\hline
\end{tabular}




$\begin{array}{ll}\text { PFI } & \text { Port Fuel Injection } \\ Q_{f} & \text { Energy Released from Burning Fuel }[\mathrm{kJ}] \\ Q_{w} & \text { Heat Loss from In-cylinder Gas to Surrounding Walls }[\mathrm{kJ}] \\ \text { RPM } & \text { Revolution per Minute } \\ \mathrm{R} & \text { Gas Constant }\left[\frac{\mathrm{kJ}}{\mathrm{kg} . \mathrm{K}}\right] \\ \text { RMSE } & \text { Root Mean Square Error } \\ \text { STD } & \text { Standard Deviation } \\ \text { SI } & \text { Spark Ignition } \\ \text { SOC } & \text { Start of Combustion } \\ \text { T } & \text { Temperature }\left[{ }^{\circ} \mathrm{C}\right] \\ T_{a d} & \text { Adiabatic Flame Temperature } \\ \text { THC } & \text { Total Unburned Hydrocarbon }[\mathrm{PPM}] \\ \text { TDC } & \text { Top Dead Center } \\ T_{i n} & \text { Intake Temperature }[\mathrm{K}] \\ \mathrm{U} & \text { Internal Energy }[\mathrm{kJ}] \\ \mathrm{V} & \text { Volume }\left[m^{3}\right] \\ \mathrm{W} & \text { Work }[\mathrm{kJ}] \\ X_{r} & \text { Residual Gas Fraction }[\%]\end{array}$




\section{Abstract}

For the past three decades the automotive industry is facing two main conflicting challenges to improve fuel economy and meet emissions standards. This has driven the engineers and researchers around the world to develop engines and powertrain which can meet these two daunting challenges.

Focussing on the internal combustion engines there are very few options to enhance their performance beyond the current standards without increasing the price considerably. The Homogeneous Charge Compression Ignition (HCCI) engine technology is one of the combustion techniques which has the potential to partially meet the current critical challenges including CAFE standards and stringent EPA emissions standards. HCCI works on very lean mixtures compared to current SI engines, resulting in very low combustion temperatures and ultra low NOx emissions. These engines when controlled accurately result in ultra low soot formation. On the other hand HCCI engines face a problem of high unburnt hydrocarbon and carbon monoxide emissions. This technology also faces acute combustion controls problem, which if not dealt properly with yields highly unfavourable operating conditions and exhaust emissions.

This thesis contains two main parts. One part deals in developing an HCCI experimental setup and the other focusses on developing a grey box modelling technique to control HCCI exhaust gas emissions. The experimental part gives the complete details on modification made on the stock engine to run in HCCI mode. This part also comprises details 
and specifications of all the sensors, actuators and other auxiliary parts attached to the conventional SI engine in order to run and monitor the engine in SI mode and future SI-HCCI mode switching studies.

In the latter part around 600 data points from two different HCCI setups for two different engines are studied. A grey-box model for emission prediction is developed. The grey box model is trained with the use of $75 \%$ data and the remaining data is used for validation purpose. An average of $70 \%$ increase in accuracy for predictining engine performance is found while using the grey-box over an empirical (black box) model during this study. The grey-box model provides a solution for the difficulty faced for real time control of an HCCI engine. The grey-box model in this thesis is the first study in literature to develop a control oriented model for predicting HCCI engine emissions for control. 


\section{Chapter 1}

\section{Introduction}

Internal Combustion Engines (ICE) have been the primary means of powering automobiles since their invention. Over the past century, various efforts have been made to improve the existing technology. During this period engineer all around the world came up with new combustion techniques, auxiliary devices, new designs, and fuels. In the past decade the automotive industry is facing new challenges thrown at it by environmental concerns and rise in fuel price. Engineers are now focusing on reducing the emission like NOx, particulate matter, $\mathrm{CO}$ and $\mathrm{CO}_{2}$ while also increasing efficiency. This period has seen the rise and application of technologies like hybrid powertrain, fuel cell and electric vehicles to meet the new emission standards and high efficiency demand by the consumer. All of these technologies are still outside the combustion; some of them like electric vehicles also eliminate the ICE completely. Out of all of the above mentioned technologies hybrid 
technology comes close to meeting the emissions demand and also high overall efficiency. However, hybrid vehicles have their own disadvantages like high initial cost, limitations on all electric miles and overall very high payback period, especially for the 2-mode hybrid technology. Fuel cell powered vehicles come very close to the final goal of zero emissions since they produces water as exhaust. Then again, such vehicles require a major change in the current setup of the infrastructure for hydrogen storage and transportation. Recent development in after-treatment systems like advanced 3-way catalytic convertors have helped reduce $\mathrm{CO}$, uHC and NOx by $90 \%$, again the use of this technology limits the use of engine only in small deviation from stoichiometry. This, in turn limits the use of lean mixtures while using the convertor. One of the technologies that has lured a lot of engineers is the LTC (Low Temperature Combustion) engines also including HCCI (Homogenous Charge Compression Ignition), PCCI (Premixed Charge Compression Ignition) and RCCI(Reactivity Charge Compression Ignition). This technology has some outstanding advantages over the conventional engines, but it also has some drawbacks. This thesis centers on experimental and modeling development of HCCI engines. HCCI engines achieve high efficiency without changing much of the existing infrastructure. HCCI incorporates the best of both SI(Spark Iginition) and CI (Compression Ignition) engines. The size of the engine is also flexible which makes it even more promising for automotive use. When controlled accurately HCCI help reduce both emission and fuel consumption. HCCI combustion can be used on wide range of fuels with different octane number. HCCI engines also offer a good scope in stationary engines due to the high efficiency 
and low emissions. This chapter consists of a brief description about the history, working, benefits, drawbacks and future scope of HCCI engines. This chapter concludes by giving an overview of the research scope and thesis organization of this thesis. 


\subsection{Background}

\subsubsection{HCCI History}

Today HCCI technology is considered new and developing but the technology has been known to engineers for more than a century. This technology is also known as Controlled Auto- Ignition (CAI) that has been luring engineers and researchers since past 100 years [3]. One of the first known patents belongs to Carl W. Weiss for inventing a hot bulb 2 stroke engine in 1897 [4]. This engine used kerosene injected onto the surface of hot bulb. The mixture was then vaporized in a heated prechamber. The combustion took place in the main chamber where the mixture entered from prechamber. The first documented study of HCCI chemical kinetics controlled combustion was done by Nikolai Semonov et al in 1930s [3]. They later went on to build the first CAI engine in 1970s [5] in which combustion of the homogenous mixture took place when the two constituents, fuel and air, entered from two different prechamber. The work done by Onishi [6] and Noguchi [7] in late 1970's was very notable, since it was premier work done to systematically study CAI. Onishi and Noguchi studied the CAI on a two stroke engine and this work was then extended to four stroke engine by Najit and Foster in 1980's [8]. HCCI term was introduced by Thring [9] while documenting the study of external exhaust gas recirculation effect and air-fuel ratio on HCCI in 1980s. After 1990s this technology gained interest from 
researchers and engineers all around the world [10-12], driven by the rise in fuel cost and stringent emission norms in US and Europe $[13,14]$. HCCI technology has excellent fuel flexibility quality [15]. This allows the technology to be applied with the use of wide range of fuels with different octane numbers. HCCI engines also exhibit the same properties over a wide range of size this allowed the technology to be implemented on a 12 liter six cylinder engine proposed by Olsson et al. [16] as well as on a 4.1 cc HCCI engine described by Manente et al. [17]. The properties of HCCI engine make it virtually work with most of the available fuels, at the same time the engine can also be scaled down to be used in any application like a small motor bike to large stationary engine used in a mine or on a ship [18]. As a result HCCI engines have a wide application base. These engines can have a very large market if the HCCI technology is enhanced and optimized to be used on a day to day basis. All these factors have led to intense research in this area in the past few decades. The following section gives a brief overview of the working of an HCCI engine and concludes with challenges faced by the HCCI engines. 


\subsubsection{Operating Principles}

HCCI engine self ignites a premixed homogenous mixture of fuel and air. This ignition is primarily done by the help of compression of homogenous mixture. So one can say that HCCI is a blend of both a SI engine and a CI engine. The fuel and air is premixed like the SI engine. In an HCCI engine, auto-ignition of the homogenous mixture takes place by compression without spark plug like a SI engine and without fuel injection like a CI engine. This helps in auto-ignition at multiple locations in the homogenous mixture.

This moves the combustion closer to an ideal cycle and hence improves the efficiency. More over the HCCI works on a very lean mixture compared to conventional engines. The homogenous mixture minimizes the formation of PM (Particulate Matter) which is a great relief with the new emission norms focused on PM. The HCCI engine has better part load efficiency compared to SI engine and also lower NOx and PM because the mixture is homogenous and combustion takes place a low temperature. Due to having low amount of PM and NOx emissions from an HCCI engine the PM and NOx after-treatment devices can be removed from the vehicle system without violating emissions standards [3]. The efficiency is further improved because the combustion takes place at high compression ratios. It helps eliminate throttling losses and shorten combustion duration. The efficiency of the diesel engine is close to $\mathrm{HCCI}$ engine but the diesel engine comes with a problem of high PM formation in the exhaust. As the charge burnt in HCCI engine is very lean and premixed, with absence of diffusion limited combustion there is negligible soot formation 
[19]. The air- fuel ratio in HCCI engine is very lean, this makes the combustion temperature low resulting in ultra low NOx emissions. This lean mixture also results in low fuel consumption compared to conventional SI engines. The above combustion characteristics make HCCI engines a promising and low cost solution to current fuel prices and emissions challenges. 


\subsubsection{Pros and Cons}

HCCI have great advantages to meet the current problems surrounding conventional engines. This section contains a brief discussion of advantages and challenges faced by the HCCI technology. As previously discussed HCCI is somewhere between SI and CI engine from the combustion view. When controlled efficiently, due to the combustion characteristics of an HCCI engine PM and NOx emissions are reduced considerably. On the other-hand there is an increase in $\mathrm{uHC}$ and $\mathrm{CO}$ emissions. This can be controlled using common after treatment devices. This is still better than controlling the NOx and soot formation in conventional CI engines. Since the combustion takes place almost instantaneously, the HCCI cycle moves closer to the ideal cycle. This helps increasing thermal efficiency. Efficiency is also affected positively due to the use of homogenous pretreated air-fuel mixture and compression ignition. This helps eliminate throttling losses and shorten the combustion duration.

The main challenges faced by HCCI are control of combustion timing, limited power output, cold start and high uHC and $\mathrm{CO}$ emissions. The control of combustion timing is done by the use of variable valve timing; exhaust gas trapping [20,21], changing the compression ratio [22,23], variable EGR [24], injection timing [25-27], and varying the intake temperature $[28,29]$. All these techniques are mainly used to control the temperature

of the mixture. The other way to control combustion process is by changing the fuel ratio 
(i.e. changing octane number of the fuel) like using two different fuel mixtures or additives to the fuel mixture. Limited power output in HCCI can be solved partially by using turbo [22, 30-32] or super charging [32-34] for boosting the air; but the main practical method is to use dual mode engines SI-HCCI [35-37] or CI-HCCI [38, 39] which provide assist coverage to full load operation and also helps for cold start.

Engineering is always governed by economics when it comes to consumer product. Thus for HCCI technology to excel in the automotive industry it needs to be economical and affordable. The main challenge is to come with simple and cost effective solutions to implement this technology to tackle the problems faced by the automotive industry. The main area of focus is to come up with combustion technique to achieve good overall efficiency keeping the emissions in check. These goals can be partly addressed by designing sophisticated combustion control system for the HCCI engine and combining this combustion technology with hybrid power-train systems. 


\subsection{Research Scope and Thesis Organization}

As we have discussed in the previous sections of this chapter, the HCCI engines face challenges like power output, high uHC and $\mathrm{CO}$ emissions, cold start and combustion control. This thesis centers on two main challenges including high uHC,CO emissions and combustion control. A grey-box model is developed for HCCI. This model can be used for predicting the uHC,CO emissions; thus, a proper emissions control technique can be devloped. In addition, the model can be used for design of neural network based combustion controller and also creating a simulation test to evaluate model-based HCCI controller. The thesis also includes details about the initial efforts taken to develop an HCCI test bed at Michigan Technological University.

In this thesis, a stock engine from a model year 2011 Buick Regal is modified to run in HCCI mode. The Chapter 2 on engine instrumentation consists details of all the modification done to the stock engine including the auxiliary components, sensors and actuators added to implement and study the HCCI engine technology.

The combustion timing, IMEP (Indicated Mean Effective Pressure), exhaust gas temperature and HCCI emissions are predicted by the using a grey-box modelling technique developed in this thesis. For the grey-box modelling, around 600 data points from two different engines are used. Out of these experimental data points Prof. C.R. Koch 
from the University of Alberta provided data from the Ricardo engine HCCI experimental setup and Dr. B. Bahri et al from Universiti Teknologi Malaysia provided the data for Yanmar engine HCCI experimental setup. Chapter 3 provides a detailed description of the grey-box modelling technique used and scope of the technique. Finally Chapter 4 summarizes the results and provides recommendations for future work.

The Figure 1.1 shows the layout in which this research was carried out and also gives the structure of the thesis.

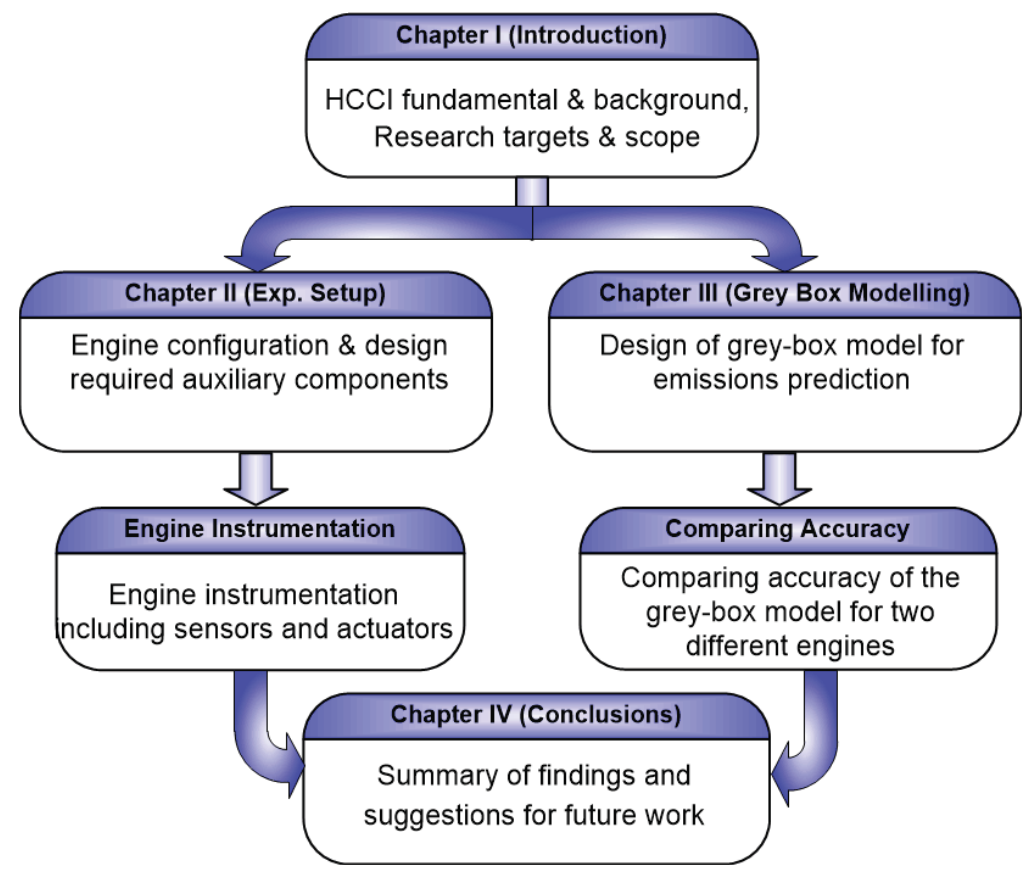

Figure 1.1: Thesis structure 


\section{Chapter 2}

\section{HCCI Engine Instrumentation and Lab}

\section{Setup}

\subsection{Introduction}

HCCI engine is a relatively new type of engine. This kind of engine is not manufactured

like conventional SI or CI engines. As a result, for this study we have used a stock engine and modified it to run in the HCCI mode. The engine required large modification so the after-market support required for the lab setup was a major factor in choosing the engine. The engine setup to run in HCCI mode has to be coupled eventually with an electric motor to perform as a hybrid system. This affected the size and power of engine that could be 
used. After studying the basic requirements of an HCCI engine and dyno test lab limitations we narrowed down the engine specifications. List of requirements for the lab engine is as follows:

$\dagger$ Displacement volume less than 2L

$\dagger$ Compression ratio around 10 but must be open for modification

$\dagger$ In-cylinder direct fuel injection system

$\dagger$ Boosted air intake

$\dagger$ Fuel flex capability

$\dagger$ Rated power should be less than $250 \mathrm{hp}$ (due to limited dyno capacity as dyno is proposed to run both HCCI engine and a $100 \mathrm{KW}$ electric motor together)

$\dagger$ High after-market support

After going through few previous studies and lab setups, we decided to go for a GM 2.0L Turbo I4 Ecotec LHU Engine. The engine selected for this study is a gasoline engine that can also run with ethanol blended fuels. The engine required auxiliary attachments and modifications to run in the HCCI mode. Specifications of the stock GM engine purchased for the lab are as listed below in the Table 2.1.

\footnotetext{
${ }^{1}$ The engine specification data is obtained from http://gmauthority.com/blog/gm/gm-engines/lhu/
} 
Table 2.1

Specifications of GM 2.0L Turbo I4 GEN I Ecotec LHU Engine

\begin{tabular}{cc}
\hline \hline Parameter & Value (units) \\
\hline Bore & $86 \mathrm{~mm}$ \\
Stroke & $86 \mathrm{~mm}$ \\
Compression Ratio & $9.2: 1$ \\
Displacement Volume & $1998 \mathrm{cc}$ \\
Valve Configuration & Dual overhead camshafts \\
Valve Lifter & Hydraulic roller finger follower \\
Firing order & $1-3-4-2$ \\
Number Valves per Cylinder & 4 \\
Fuel System & Direct injection \\
Fuel Type & Premium recommended, Fuel flex capabilty \\
Rated Power & 220hp (164 kW)@ 5300 RPM \\
Rated Torque & 260lb.-ft (353 Nm)@ 2400 RPM \\
Maximum Engine Speed & $6350 \mathrm{RPM}$ \\
\hline
\end{tabular}


This chapter consists the overview of the modifications and tasks completed to setup a stock engine to run in the HCCI mode(Table 2.2 and Table 2.3). This chapter also provides details of the sensors and actuators mounted on the engine for data acquisition.

Table 2.2

Auxiliary parts added to the engine.

\begin{tabular}{ll}
\hline \hline Auxiliary Parts & Reason \\
\hline EGR valve & To control EGR into the system \\
EGR cooler & To cool the EGR to desired temperature \\
Thermocouples & To measure temperature at various location \\
Pressure transducer & To acquire and study pressure data various \\
& locations \\
Lambda sensor & To measure and monitor air-fuel equivalence \\
& ratio \\
Air heater & To increase the intake air temperature to \\
& enable HCCI operation even with low \\
& compression ratio engine \\
Crankshaft encoder & To measure crank rotation at specified sample \\
rate & To cool the compressed intake air \\
Intercooler & To supply boosted intake air while the \\
Super-charging station & original turbocharger is not used \\
\hline
\end{tabular}

Table 2.3

Modifications required on the engine.

\begin{tabular}{ll}
\hline \hline Modification tasks performed & Reason \\
\hline Flywheel modification & To connect to dyno using universal joint \\
EGR circuit & To introduce external EGR to help \\
& auto-ignition process $[28,29]$ \\
Change compression ratio & To help auto ignition process \\
ECU debugging connectors & To read all the OBD data and make the \\
& necessary changes to run the engine \\
Fuel system and intake air ports & To add port fuel injection capability \\
\hline
\end{tabular}




\subsection{Engine Mounting}

After the selection of the engine, the next task was to mount the engine on the cart in-order to connect it with the test cell dynamometer. The test cell has an AC dynamometer which has a $460 \mathrm{hp}$ capacity. The test cell is equipped with its own data acquisition system which processes the data and displays it on the work station outside the lab. This workstation is planned to control the load, dynamometer, air heater, EGR, and coolant flow. The workstation is also used to monitor the pressure and temperature of the engine components. The workstation controls the basic engine operation and a prototype engine control unit (ECU) dSPACE Micro AutoBox is used for advanced combustion controls.

The engine mount and sizing of the parts in connection with the test cell were initially designed using CATIA and SolidWorks. The design of some components were not to scale initially but as products were purchased, the design was reviewed and the necessary changes were made.

The Figure 2.1 shows the initial design of the engine mount. The engine is connected to the cart with the help of four jack stands as seen in the Figure 2.1. The purchased engine, being a stock engine required a horse collar to be connected to the jack stands in order to be mounted on the cart. The horse collar was designed according to the requirement, but the manufacturing had a very big lead time on it. So with the help of some modifications 


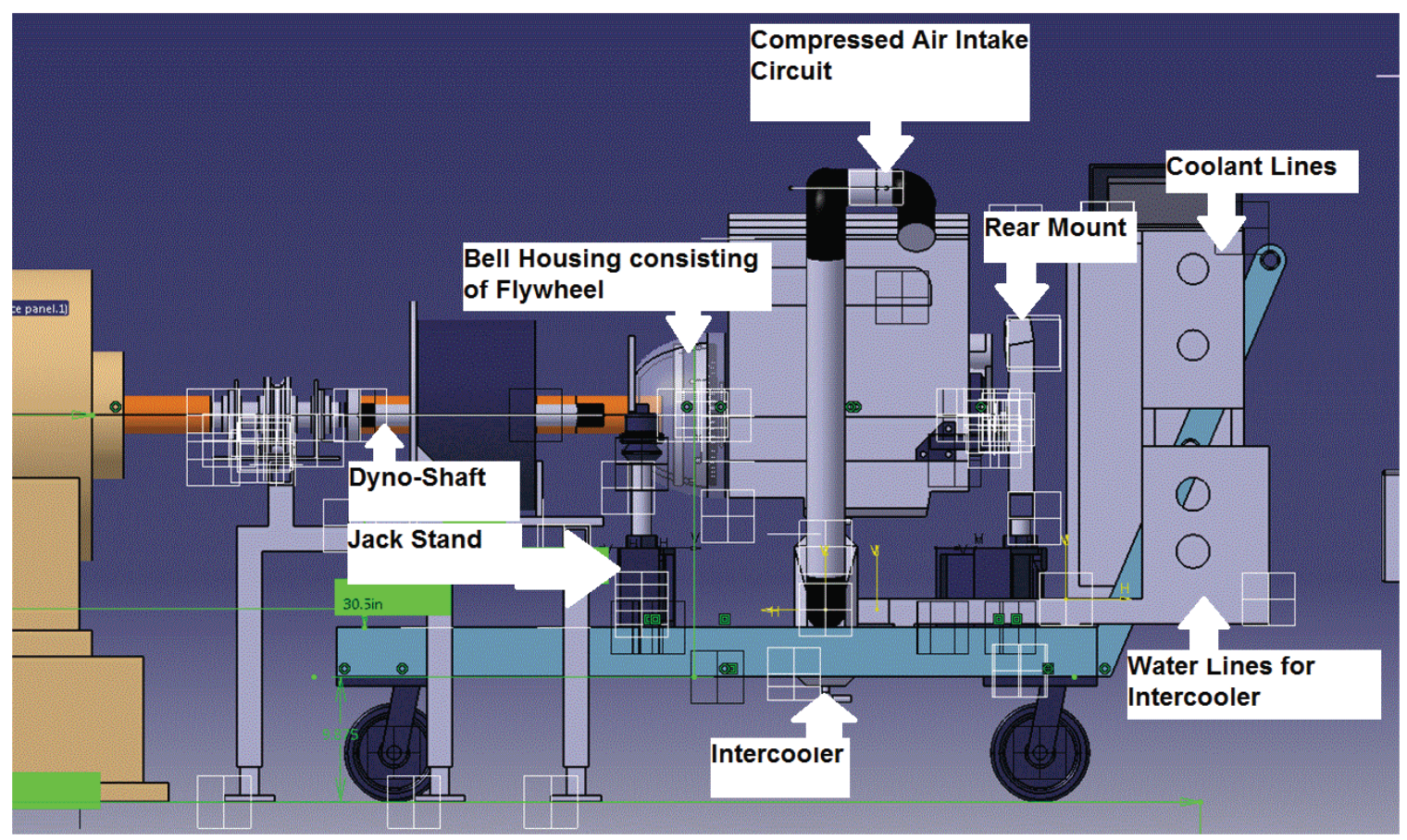

Figure 2.1: 3D Engine Mount (photo by author).

a transmission bell housing with similar features was used along with a 1.5 " thick steel plate. The steel plate and housing were connected by using high strength bolts and nuts. The steel plate was machined in-house and a used transmission was purchased resulting in reduced cost and lead time for the engine mount process. The rear mount for the engine was manufactured and designed in-house using 1" square steel channel as seen in the Figure 2.1. This frame is connected with the jack stands using square thread bolts. The frame is then connected to engine with a damper to reduce the vibrations. Figure 2.3 shows the final mount of the engine. A single mass flywheel is used for the the test setup. The flywheel purchased required a small modifications and was mounted to engine as shown in the Figure 2.2. The horse-collar and steel plate was mounted over this flywheel arrangement. Once the engine was mounted correctly, a dummy dynamometer setup was used to check the 


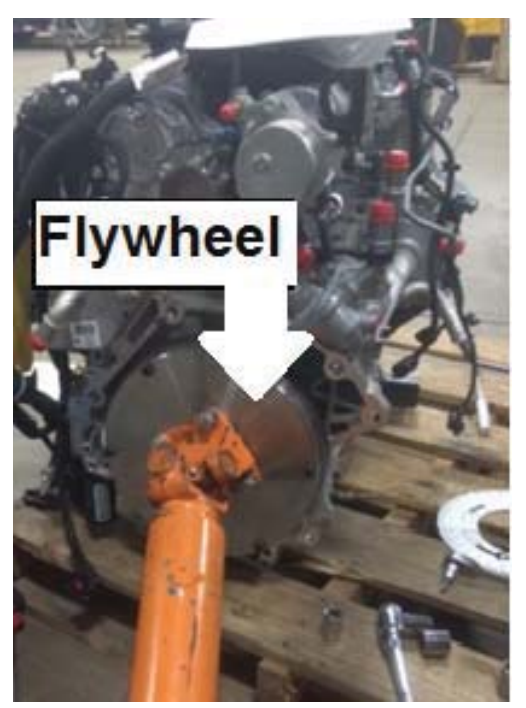

Figure 2.2: Flywheel Mount (photo by author).

height and alignment of the shaft with respect to dynamometer shaft; in-order to have zero clocking and misalignment of the shafts. A misalignment of the shaft can result in high vibration which can cause a considerable damage to the dynamometer, engine and also results in misinterpreted pressure data. The Figure 2.3 shows the final engine mount.

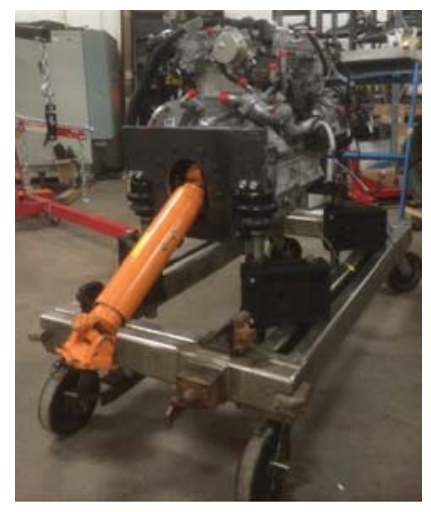

(a) Engine Front Mount

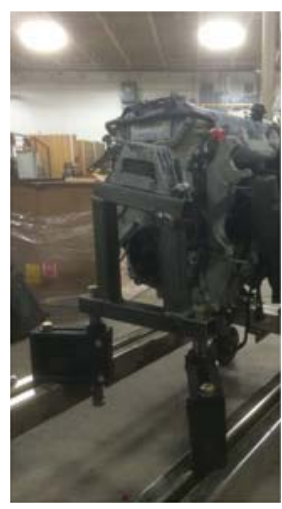

(b) Engine Rear Mount

Figure 2.3: Final Engine Mount (photo by author). 


\subsubsection{Interface Panels}

The interface panel was designed and mounted on the engine cart to make systematic connections. These connections are used for passing signals from the thermocouples and pressure transducers to the lab data processing and acquisition system. The panel is also used for making all the electrical connections to the engine, ECU, sensors, and actuators. This makes the design and manufacturing of the panel a critical part. The weight of the part was factor for material selection, hence an aluminum plate of $0.25 "$ thickness was used. The engine cart consists two aluminium panels and one steel panel both of $0.25 \%$. One interface panel is purely used for electrical connections Figure 2.4 (b) and is placed on one side of the engine cart and the other Figure 2.4 (a) is used for water connections, coolant connection and fuel lines. This panel was placed on the other side of the engine opposite to the electrical panel. The panels were designed using CAD tool. The final design is shown in Figure 2.4. Once the designs were finalized, they were given for manufacturing to a vendor.

These panels were then mounted on an aluminum frame which finally bolted down to the engine cart. Figure 2.5 shows the final manufactured interface panels. 


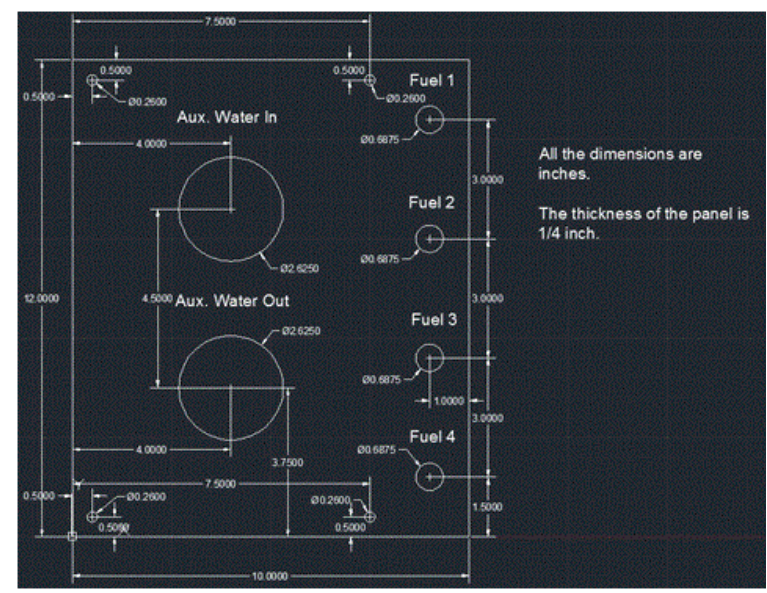

(a) Interface panel for fuel and water lines 2D design

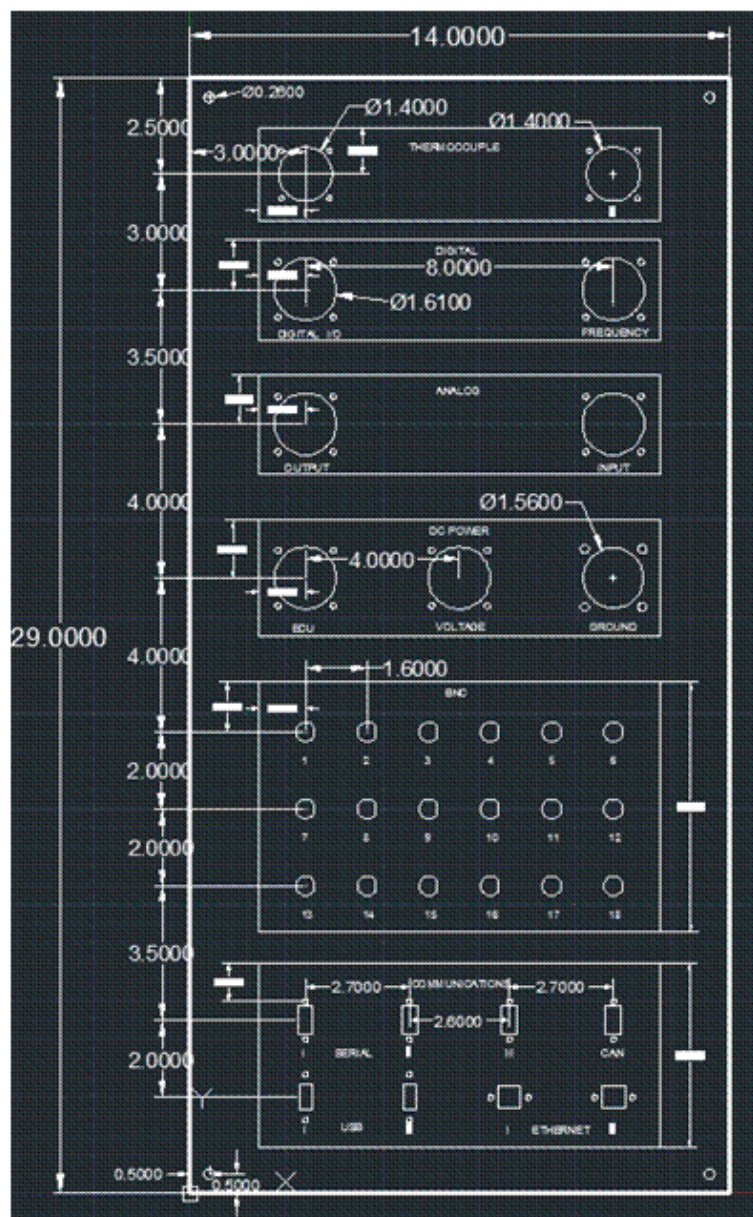

(b) Interface panel electrical connections 2D design

Figure 2.4: 2D Design of interface panels. 


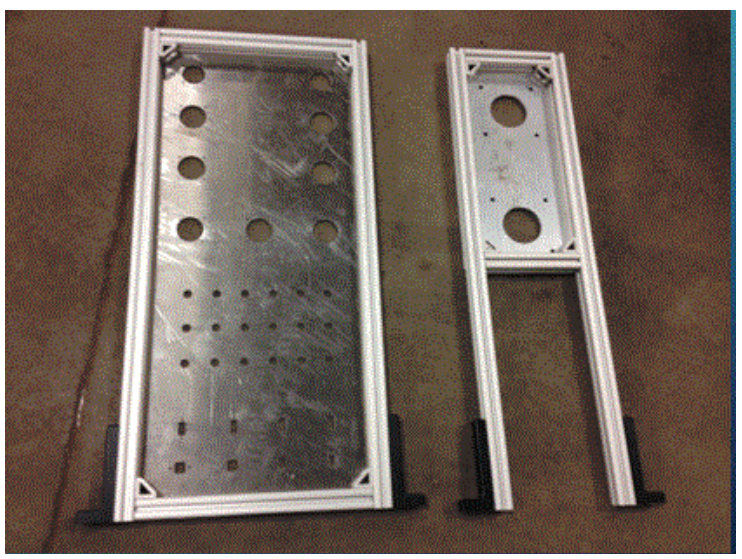

Figure 2.5: Manufactured interface panels (photo by author). 


\subsubsection{Coolant and Water Lines}

The coolant lines are used for circulating the coolant in the engine. The water lines are used to circulate water in the intercooler used for cooling the compressed intake air and also EGR cooler to cool the recirculated exhaust gas. The coolant lines were connected by valves on one side to the test cell while the other side was connected to coolant-in and coolant-out connections on the engine. The coolant lines were connected using flexible 1.5 " inner diameter coolant hose and steel pipes 1.5 " outer diameter and 90 elbows. The steel pipes and elbows were used to mount the pressure transducers and thermocouples in the coolant path to acquire the temperature and pressure data for coolant, respectively.

The shut-off valves on the bottom of Figure 2.6 were used to connect and control the water flow to the intercooler from the test cell. While the steel connectors were used for the coolant lines, the water connections from the connectors on the panel to the intercooler were made using 1" flexible hose, barbed connectors and hose clamps as shown in the Figure 2.6. 


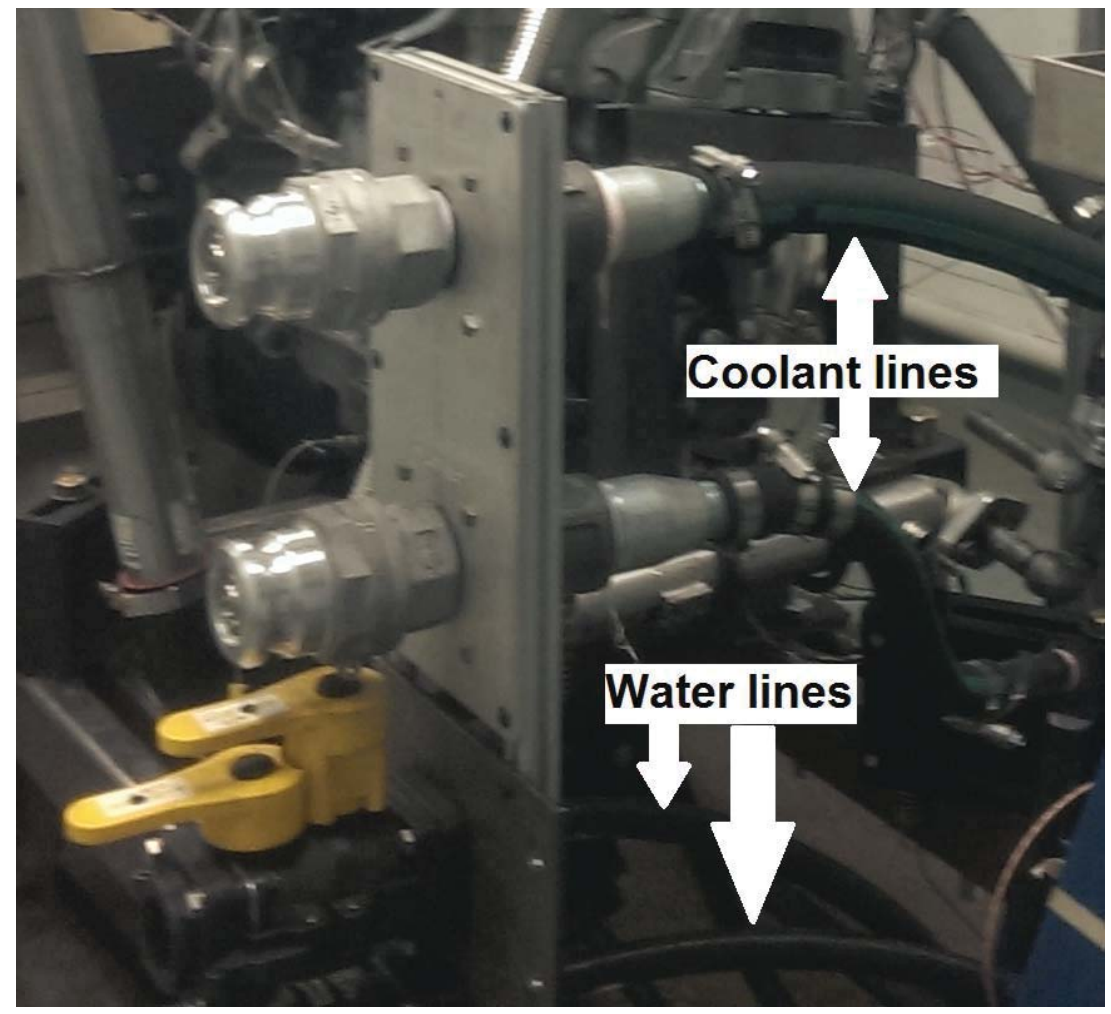

Figure 2.6: Coolant and water lines connections (photo by author). 


\subsubsection{ECU Mount}

The ECU mount was one of the difficult things to do as it was very critical and had to be mounted on location where the engine wire harness easily reached. Figure 2.7 shows the way the engine harness was mounted. A 1" thick foam was used to mount the engine on a $0.25 "$ thick aluminium plate. This aluminium plate was connected to the frame of the electrical panel on one side of the engine by using 90 degree bents for the aluminum frame. The ECU and the foam were tied to the plate by using conventional zip ties. 


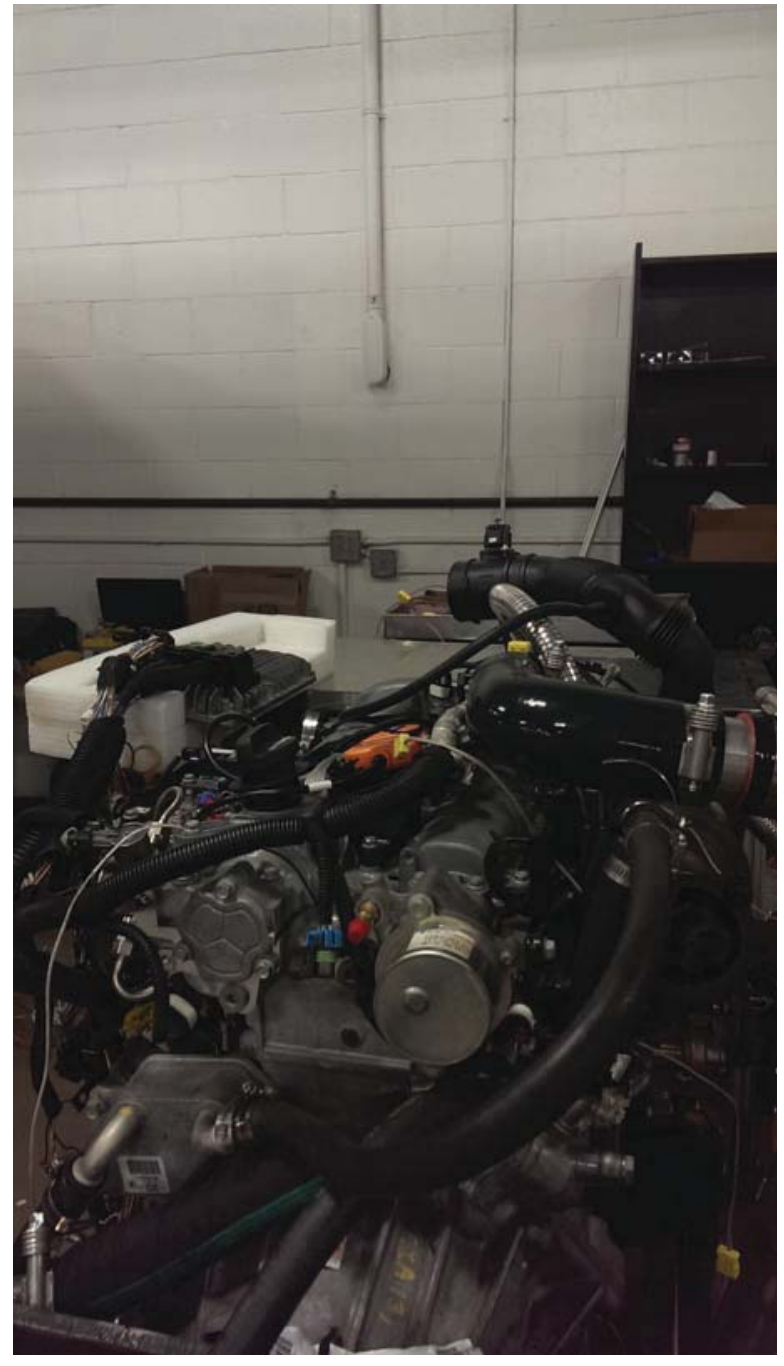

Figure 2.7: ECU mount (photo by author). 


\subsubsection{Intake Air Circuit}

The intake air circuit consists of turbocharger, intercooler, air-heater, EGR intake, throttle body, and finally intake manifold. The design of the circuit required a lot of revisions before the final design. The final design was created using Catia as shown in Figure 2.8. A stock part was used for connecting the fresh intake air to the turbocharger inlet as shown in Figure 2.9. The section of air circuit marked as fresh air intake in Figure 2.9 deals only with air at room temperature and atmospheric pressure. This section is connected to turbocharger inlet. The turbocharger outlet is connected to the steel exhaust pipe using a silicone flexible pipe and high pressure hose clamps. The flexible silicone piping used for this purpose has a thermal rating of $180^{\circ} \mathrm{C}$ and the hose clamps are rated for high pressure use. This section is used for passing the compressed air from turbocharger outlet to the intercooler inlet where it is cooled. The fabrication and design of the intercooler mount was done inhouse using a 0.25 " thick steel plate. The intercooler is mounted centrally beneath the engine on the cart. The water connections to the intercooler were made as described in the Section 2.2.3 of this chapter. Two flexible silicone $90^{\circ}$ elbows were used on either side of the intercooler. One silicone bend pipe was used to connect the turbocharger outlet to the intake of the intercooler and the other silicone bend pipe is used to connect intercooler outlet to the air-heater intake for the cooled compressed air. The air heater was connected on one end to the intercooler and the other end to the throttle body by using a straight silicone flexible hose and high pressure hose clamps as shown in Figure 2.10. The throttle 
body is currently connected to the engine as per manufacture's specifications but there are plans to change this in order to accommodate the EGR intake tap. The complete air intake circuit is designed in such way that it can accommodate any major change if required in future.

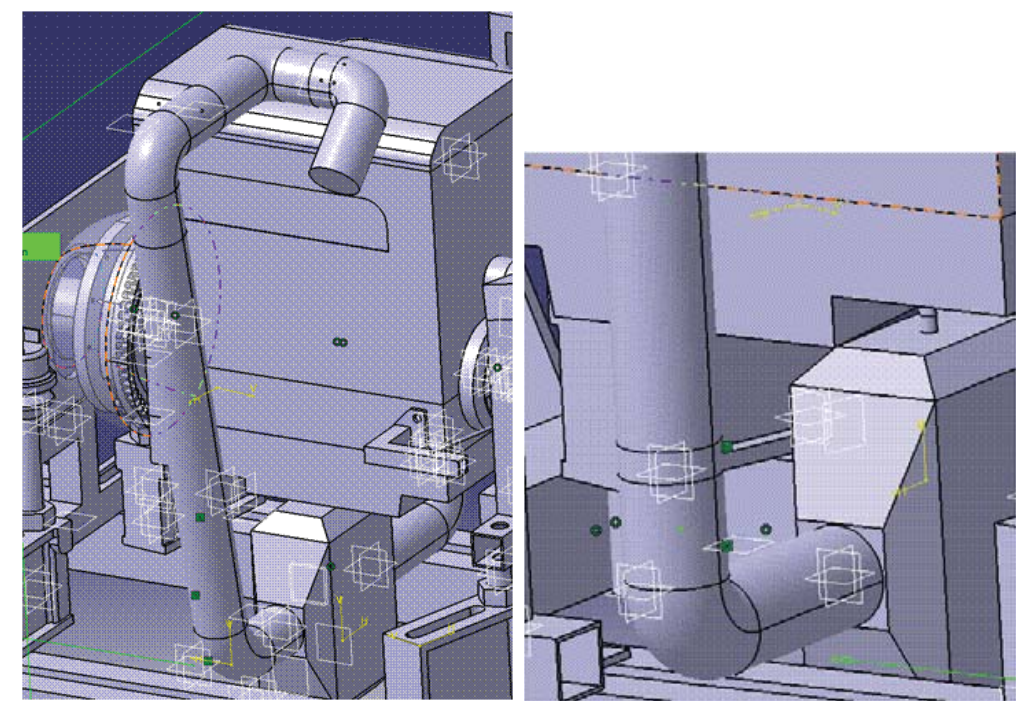

Figure 2.8: 3D design for post turbo intake air circuit.

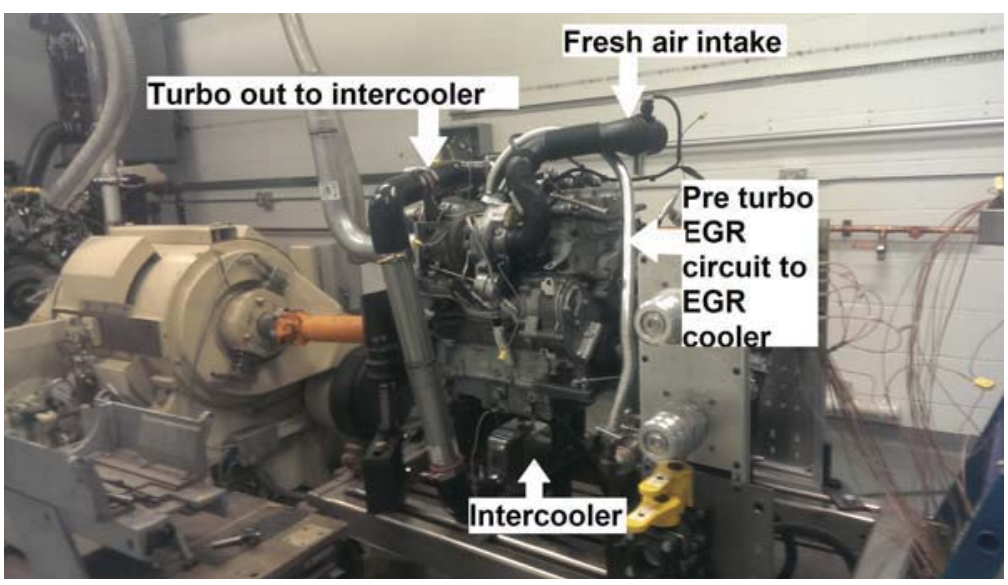

Figure 2.9: Intake air circuit (photo by author). 


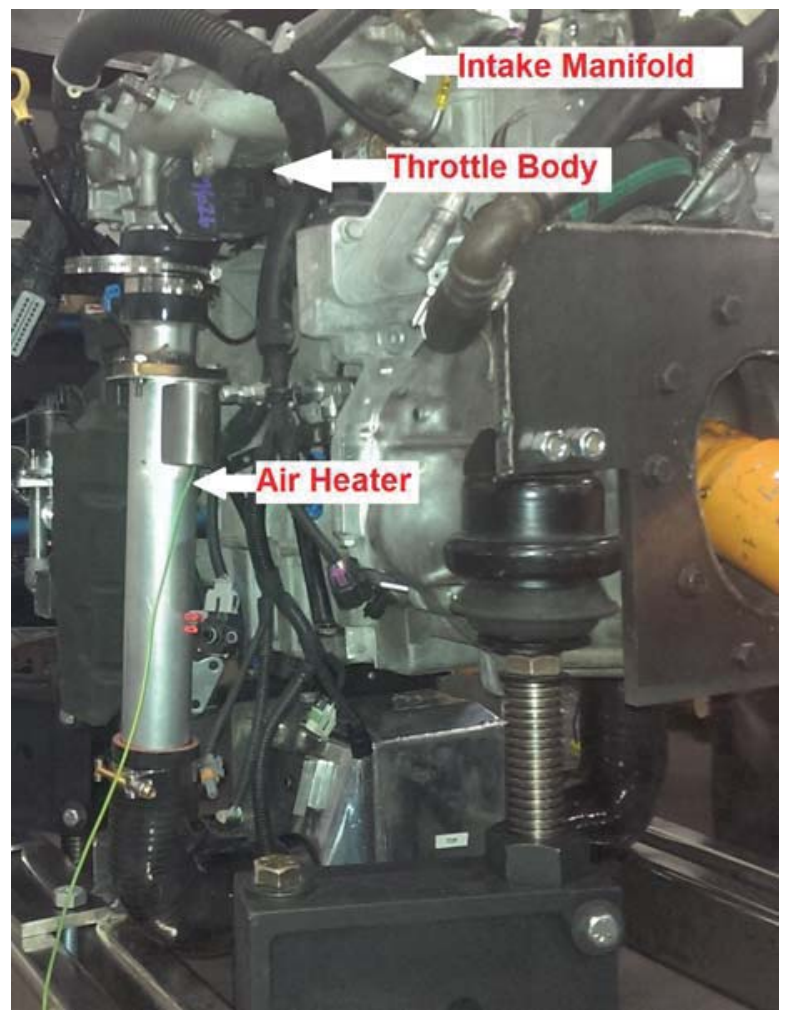

Figure 2.10: Compressed air cicuit from intercooler outlet to air-heater inlet (photo by author). 


\subsubsection{Exhaust Gas Recirculation Circuit}

EGR can facilitate in the auto-ignition process in an HCCI engine [28, 29]. This section covers the modifications done to the test engine in order to introduce EGR in the setup. The current engine did not have EGR pre-installed so a pre-turbo EGR circuit was designed and implemented. The exhaust manifold was drilled and a pipe extension was welded in order to make room for the exhaust pipe connection. This pipe was then connected to the EGR cooler. The EGR cooler was used to cool the hot EGR gases from the engine exhaust manifold by using a water cooled heat exchanger. The other end of the EGR cooler is connected to the EGR valve using 0.5 " diameter pipes. Finally the EGR valve outlet was connected in the path of the intake air before the intake manifold. The EGR valve and EGR cooler are both from Ford F150 pickup. The current location of pre-turbo EGR tap can be easily changed to post-turbo by simply connecting the pipe to a post turbo location before the lambda sensor mount. The location of EGR intlet in the intake air path is also open for modifications. The complete circuit is very flexible and can be modified in future as required. The EGR cooler was mounted on the rear mount frame using U-bolt clamps and dampeners to reduce vibrations. The EGR valve and EGR cooler mount can be seen in Figure 2.12. 


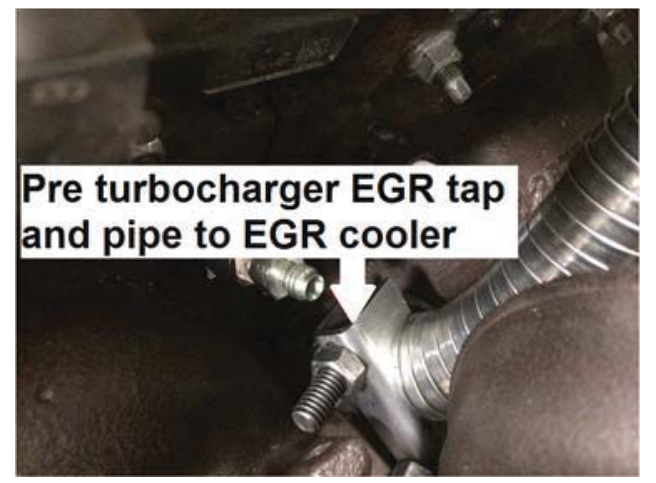

Figure 2.11: EGR tap on exhaust manifold before the turbocharger (photo by author).

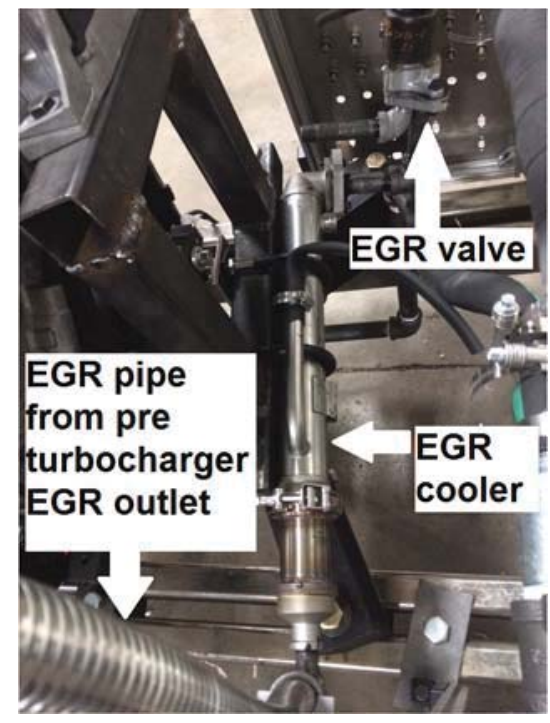

Figure 2.12: EGR cooler mount and connections (photo by author). 


\subsection{Sensors \& Actuators}

The engine is instrumented with a number of sensors mounted on the engine for data collection and monitoring. The engine is a stock engine which is modified for the lab application; thus, there are added auxillary parts like air heater, shaft encoder, lambda sensor, many new sensors mounted on the engine. Figure 2.13 gives an overview of all the sensors and auxillary parts mounted on the engine. This section covers the topics of thermocouples, pressure transducers, shaft encoder, lambda sensors and in-cylinder pressure sensors, including their mounting and wiring.

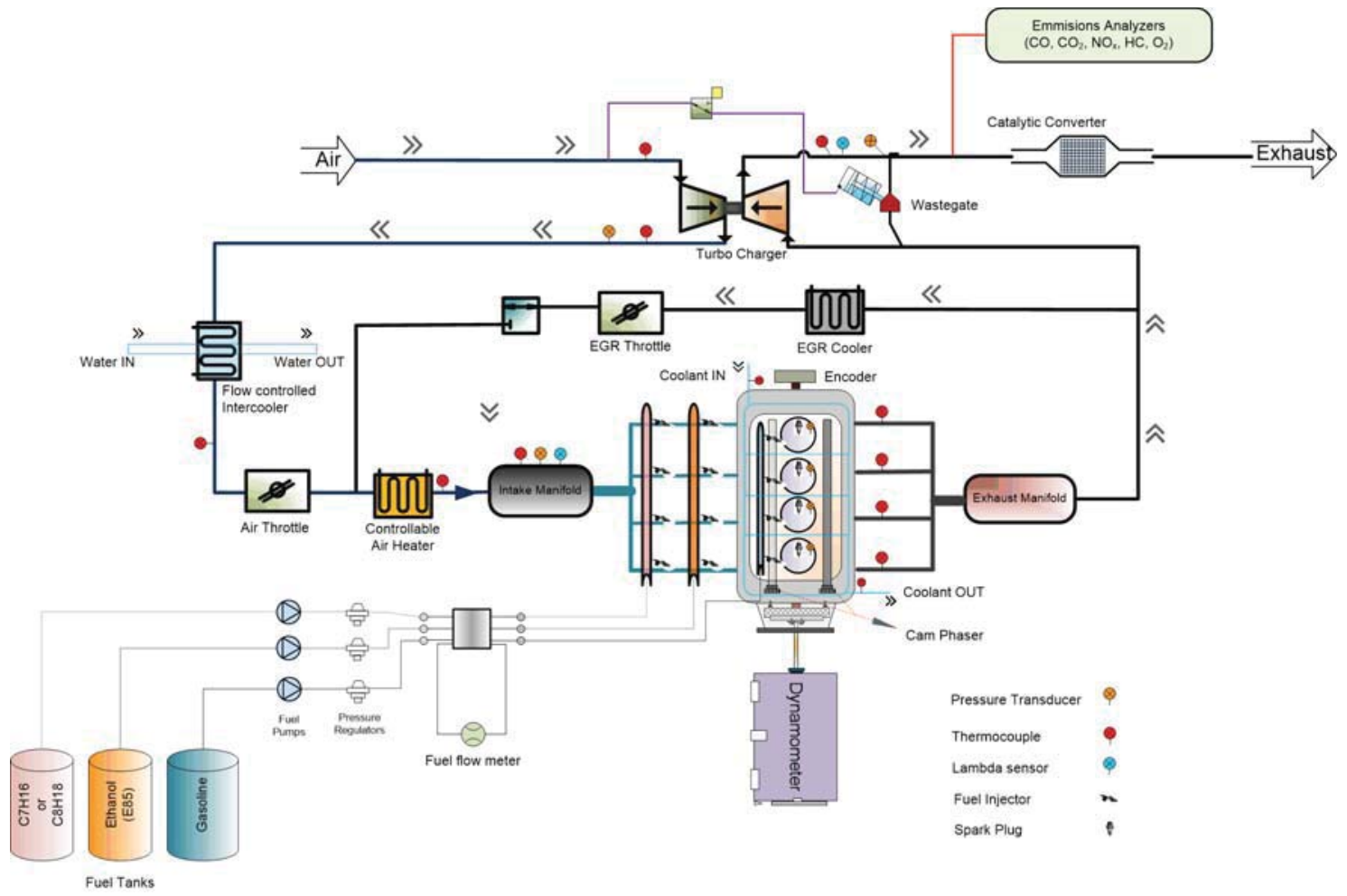

Figure 2.13: Overview of lab setup with newly added sensors and parts. 


\subsubsection{Thermocouples}

The thermocouples used for this lab setup are all K-type. The thermocouples were mounted at the locations shown in Figure 2.13. They were mounted using 0.25" NPT fittings on the pipes as shown in Figure 2.14. The pressure check was performed for the joints and the mounts in order to prevent leaks of coolant and gases.

\subsubsection{Pressure Transducers}

Two types of pressure transducers were used in this experimental study: absolute pressure transducers and gauge pressure transducers. Two absolute pressure transducers were mounted on intake manifold and exhaust gas pipe after turbocharger, respectively. The absolute pressure transducers were used to measure the accurate boosted air pressure in the intake manifold. The rest of the pressure transducers measure gauge pressure. The absolute pressure transducer have 0-5 Volt D.C. excitation, 0.5\% FSO and 0-50 psi range [40] .The pressure transducers are mounted as shown in Figure2.13. They were mounted on tee joint along with thermocouples on most locations using a barbed fitting. A pressure check similar to thermocouple was performed with 4 bar compressed air to check for leaks. 


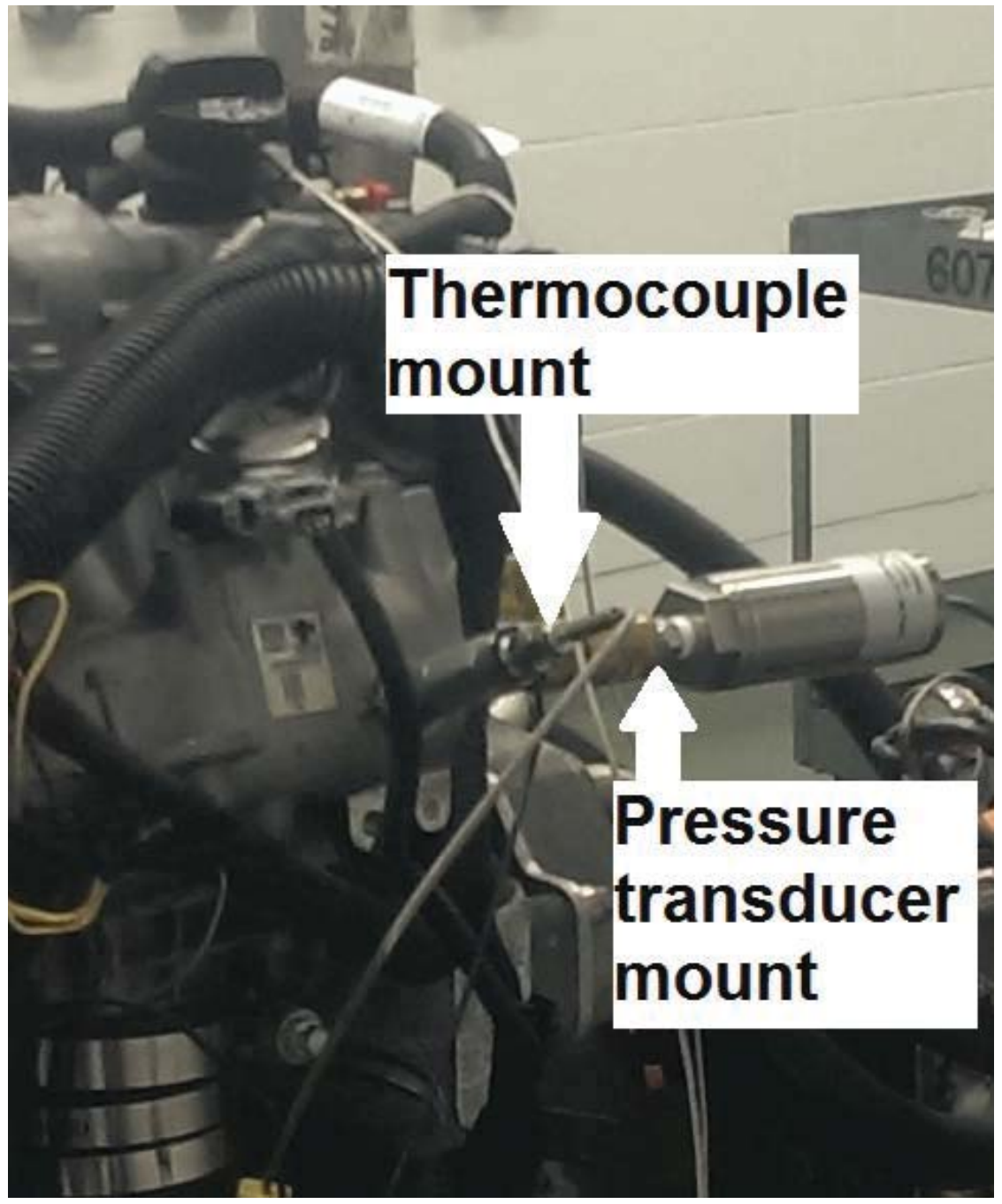

Figure 2.14: Pressure transducer and thermocouple on the intake manifold (photo by author). 
The in-cylinder pressure sensors are needed to measure in-cylinder pressure trace data during the engine cycle. The data recorded by these sensors is critical for studying the combustion performance of the engine. Proper mounting of these sensors inside the cylinder head is a critical task. The position of the sensors was decided by studying the previous test engines at the university. The pressure sensors were mounted on a machined new cylinder head by Endres Machining, Houghton,MI.

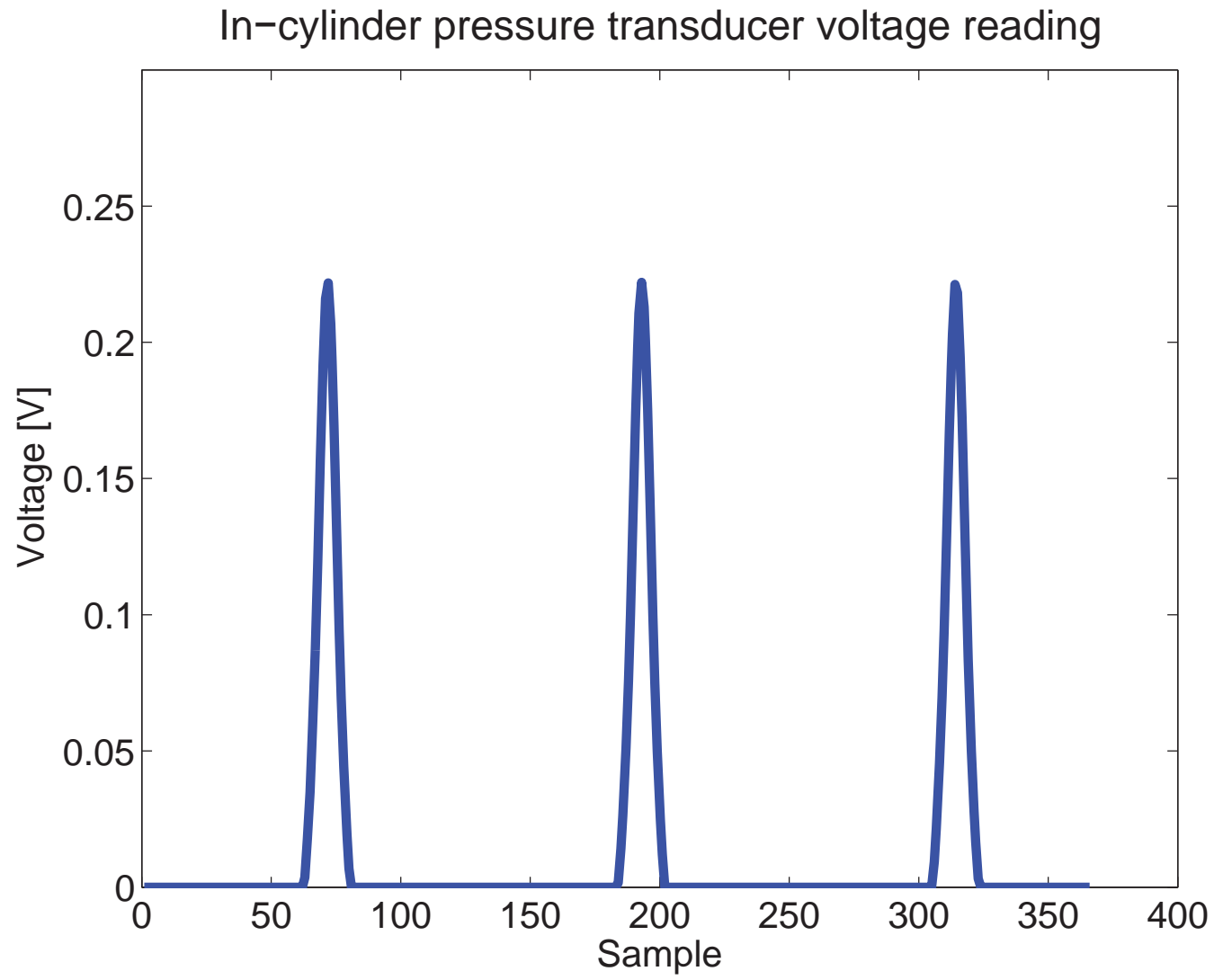

Figure 2.15: In-cylinder pressure transducer voltage reading.

Figure 2.15 shows the plot generated using the measured output voltage from an in-cylinder pressure transducer. This voltage will be converted to respective pressure reading using 
the test cell data acquisition system and manufacturer's specification sheet. The pressure sensors are by PCB piezotronics and a special finishing tool was used to complete the mount of these sensors. The machined cylinder head with the pressure sensors was then swapped with the original cylinder head. There are four sensors mounted one for each cylinder. Specifications of this sensor is provided in the Appendix C. 


\subsubsection{Shaft Encoder}

An external shaft encoder is be mounted on the engine to measure the crankshaft rotation at a specified sample rate. This data is linked with the in-cylinder pressure data to study the engine performance under different operating conditions. For this study an Accucoder encoder model $260^{2}$. The encoder is a 4-pole front mount encoder with bore size of 0.625 " [41]. The encoder uses a line driver. The encoder coonected to the data acquisition system using a 8 pin M12 male connector. The shaft encoder was mounted on the opposite side of the dyno shaft. The design of the encoder on the existing engines was studied and 3D model was developed based on the study. The 3D model was then modified according to the requirements of the current engine and encoder dimensions. The following Figures 2.16 and 2.17 show the 3D model of the encoder mount. The parts for the mount were fabricated and manufactured by REL Manufacturing Figure 2.18. The material used was mild steel.

\footnotetext{
${ }^{2}$ Crankshaft encoder with part number $260 \mathrm{~N}-\mathrm{R}-11-\mathrm{S}-0360-\mathrm{R}-\mathrm{HV}-1-\mathrm{SMK}-\mathrm{FA}-1-\mathrm{N}$ is used
} 


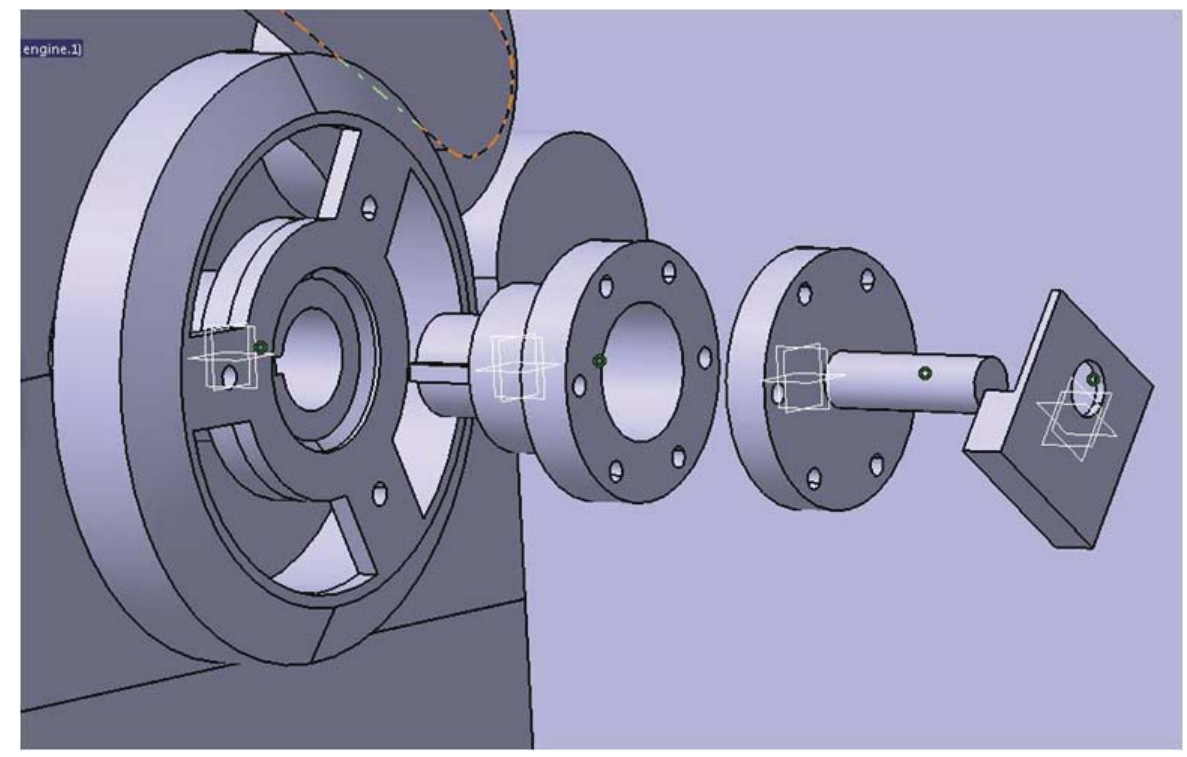

Figure 2.16: Exploded view of encoder mount 3D design.

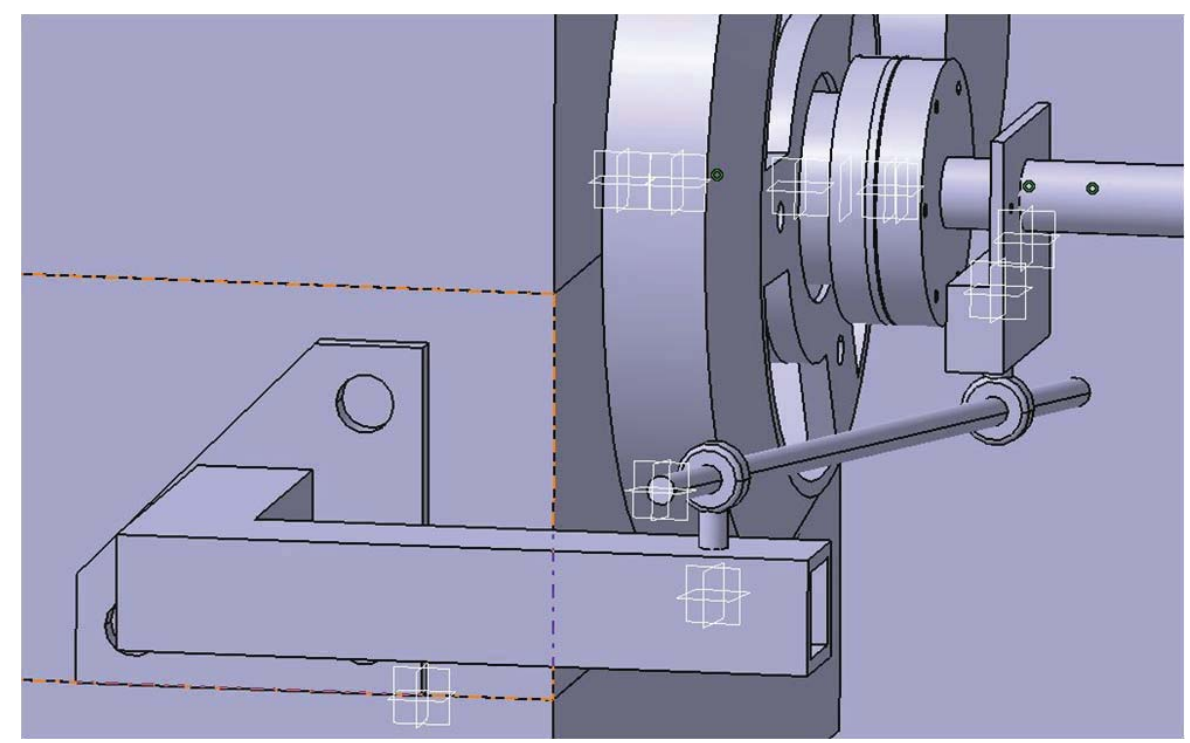

Figure 2.17: Encoder mount 3D design. 


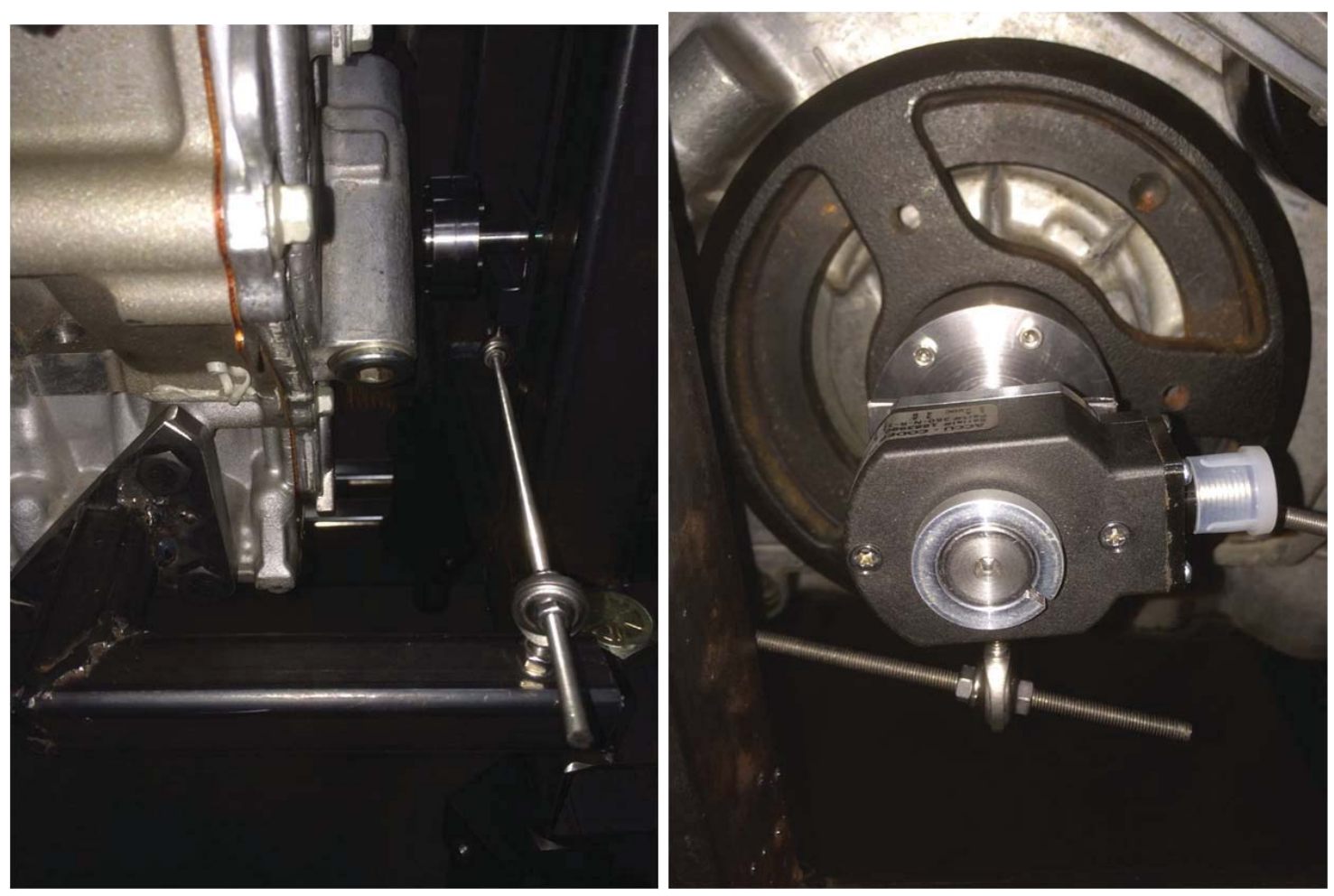

Figure 2.18: Manufactured encoder mount (photo by author). 


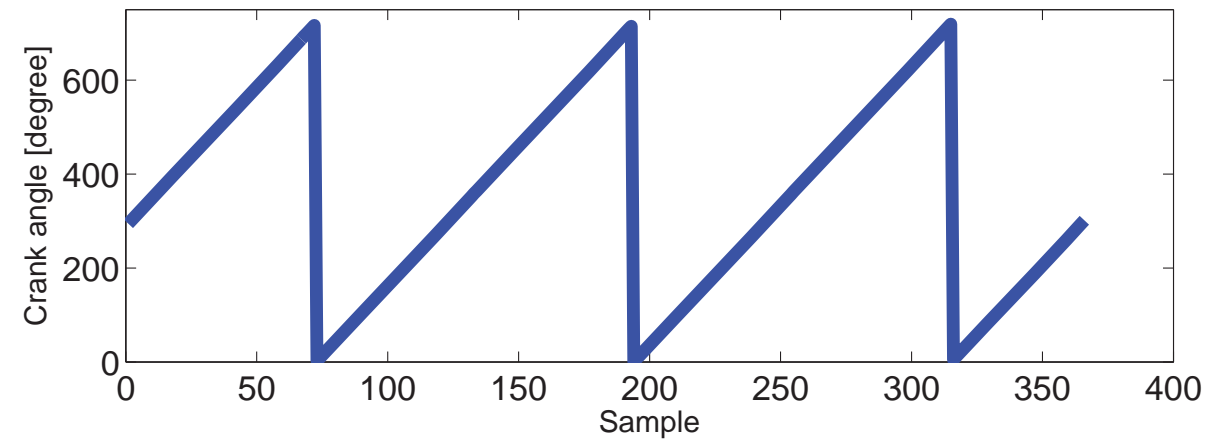

Figure 2.19: Crank angle reading. 


\subsubsection{Lambda Sensor}

A BOSCH LSU 4.9 lambda sensor is used to measure air-fuel equivalence ratio. The sensor is a wideband UEGO (Universal Exhaust Gas Oxygen) type which can operate under very lean engine operating conditions. The main reasons for using this model were it's compatibility with the dSPACE controller and its ability to work with very lean air fuel mixtures which are commonly used in HCCI engines. The characteristic curve for the sensor has almost constant slope for $\lambda=0.65$ to infinity (air) makes this model suitable for use in HCCI application [42]. The Lambda sensor is mounted on the exhaust pipe after the turbocharger as shown in the Figure 2.20. The Lambda sensor was connected to the dSPACE module as per the wiring diagram and the calibration was done using the details in the data sheet shown in Appendix C.7, C.8 and C.9. The block diagram in the data sheet was used as a reference for mounting and wiring the sensor on the exhaust pipe.

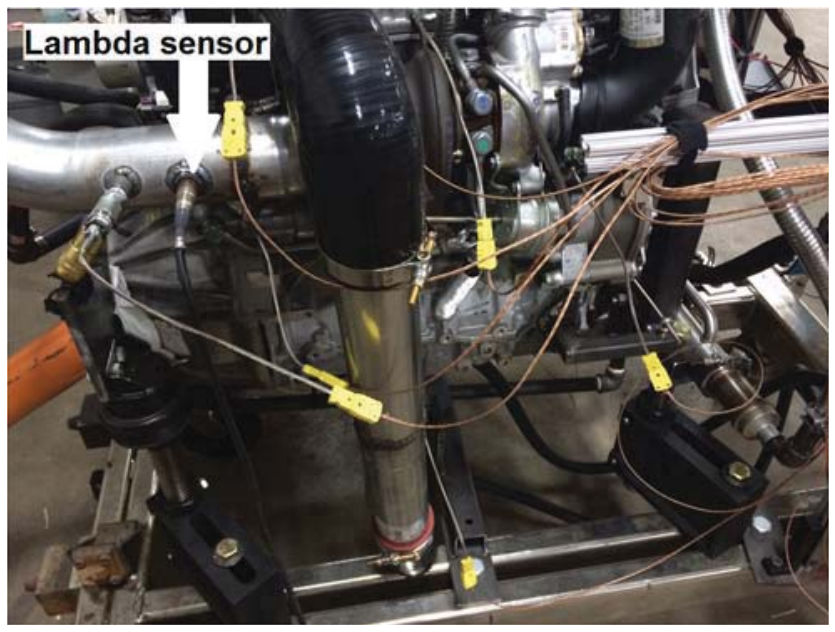

Figure 2.20: Lambda sensor mount (photo by author). 


\subsection{Wire Harness and OBDII Connections}

The engine was purchased along with stock a ECU and wire harness. The wire harness was carefully studied with the help of available books from Mithcell1.com. Next, necessary wires were connected to the OBDII connector. This connector was purchased separately and was important in order to communicate with the ECU. The ECU codes and flags can be read using the OBDII connections. This is the easiest way to change the engine calibration and communicate with the stock ECU. This step is necessary in order to run the engine in the test lab. Figure 2.21 shows the connections made to the OBDII connector.

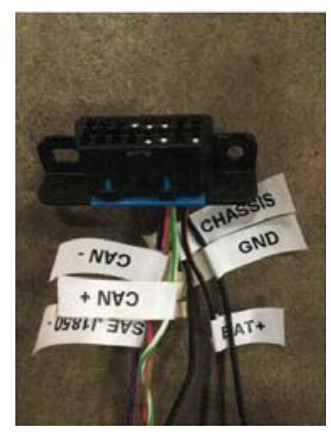

Figure 2.21: OBDII connector wiring (photo by author).

The important connections on the OBDII connector are the CAN wires, battery positive for 12 volt, chassis, and ground connection. Both chassis and ground were connected to the common ground on the instrument panel and the positive wass connected to the 12 volt positive supply on the engine cart. The CAN wires are used for communication with the ECU, stock sensors on the engine, and the throttle body. All the thermocouple wiring 
was made on the electrical instrument panel, as shown in Figure 2.22. Similar wiring was done for pressure transducers. This wiring of the connectors on the instrument panel helps operator to easily connect all the engine sensors and actuators with the test cell harness. The wiring is also made to provide one common positive supply for all devices requiring 12 volt and also for devices requiring 5 volt. In addition, the instrument panel has common ground which is used to connect all the ground connections on the engine and cart to the test cell ground.
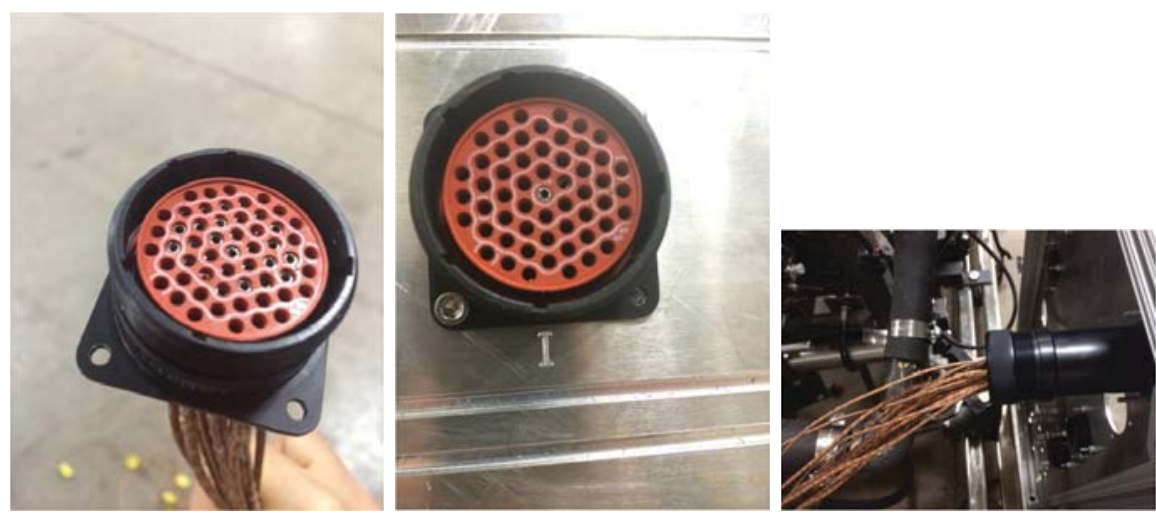

Figure 2.22: Thermocouple wiring (photo by author). 


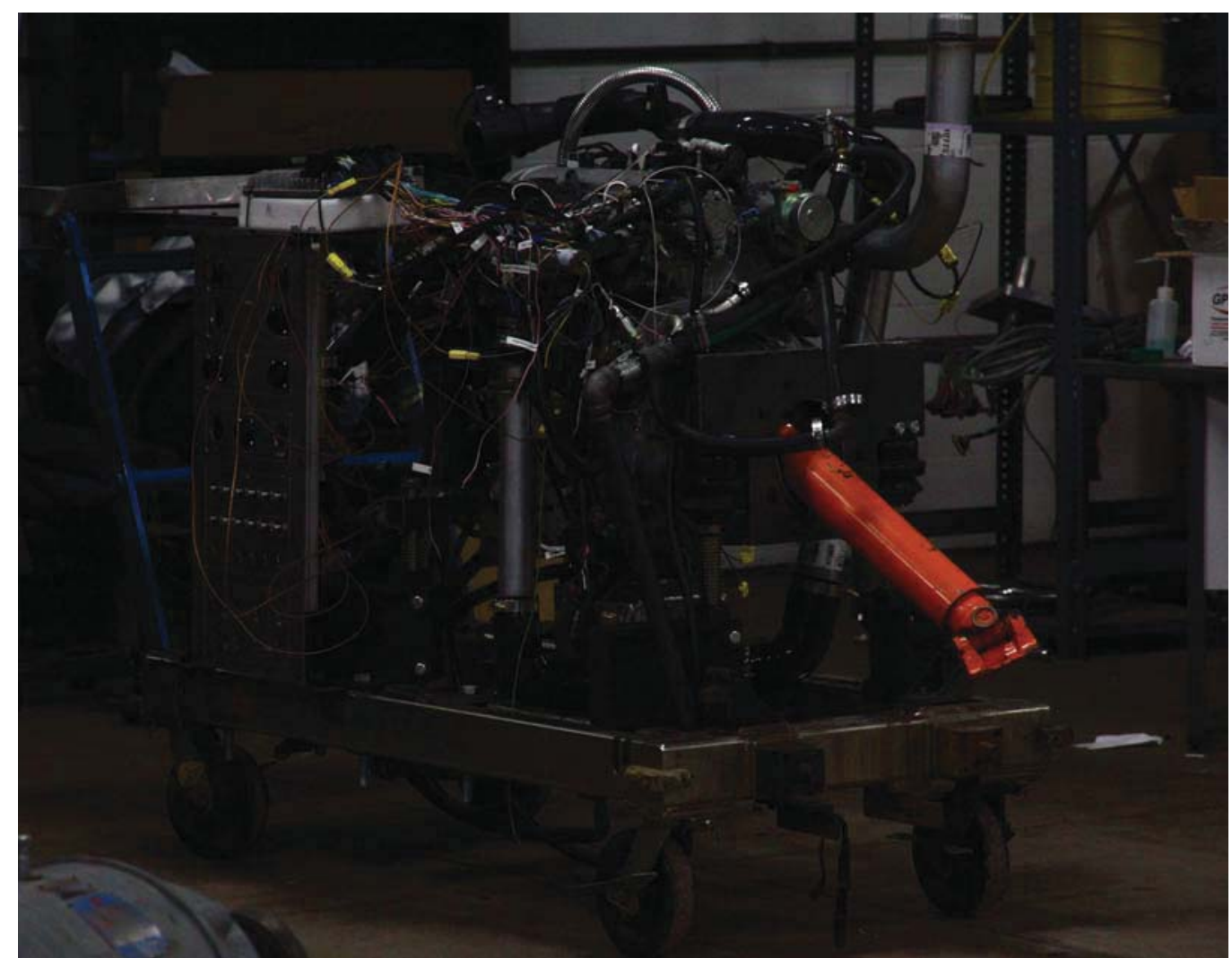

Figure 2.23: Final engine mount (photo by author). 


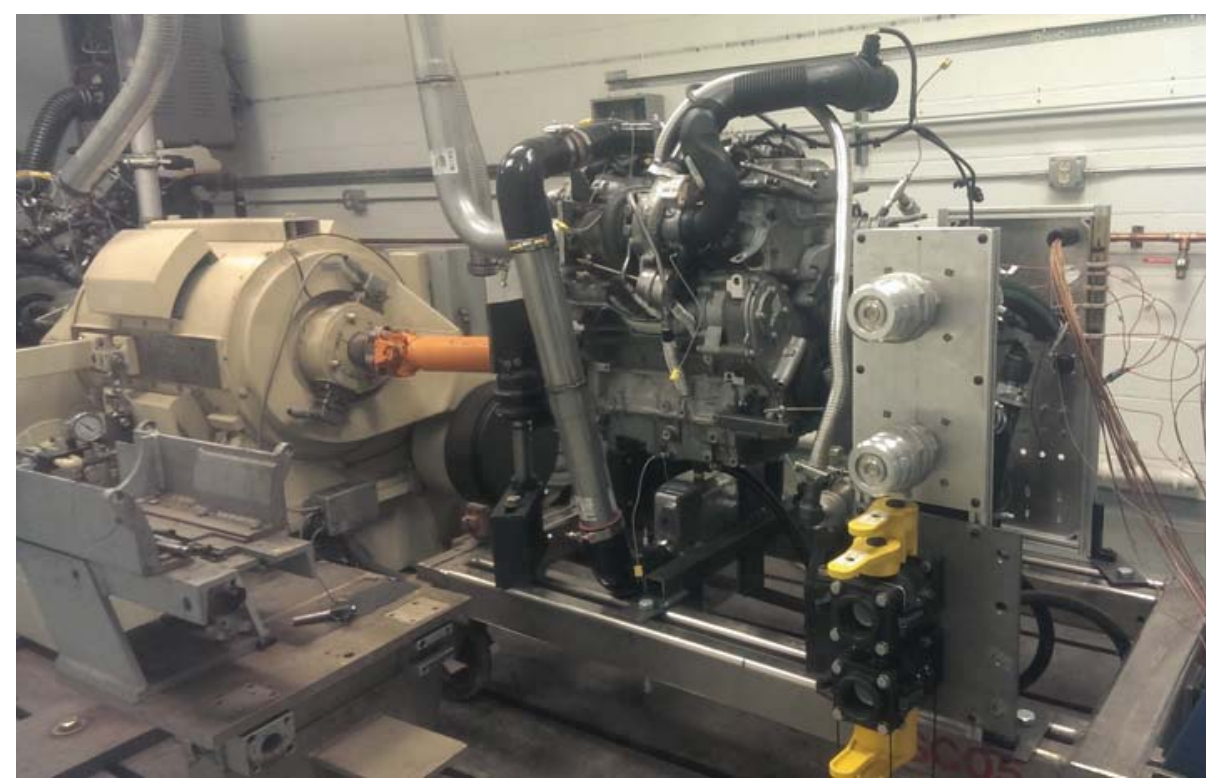

Figure 2.24: Final engine dyno setup (photo by author). 


\subsection{Summary}

This chapter covered the details of the engine setup developed for future HCCI studies at Michigan Technological University. A 2.0 litre GM GEN I Ecotec LHU was modified in order to run in the HCCI mode. The modification includes adding intake air heater and introduction of an EGR loop. A number of parts were manufactured to assemble the engine setup. A lambda sensor, crank shaft encoder, temperature sensors, and different pressure sensors were mounted on the engine. The data sheets of all sensors are provided in the Appendix C. The final engine setup has been tested in both motoring and firing SI modes. The experimental work from this thesis created a base HCCI engine setup which will be extended in future for HCCI engine studies. 


\section{Chapter 3}

\section{Grey Box Modeling of HCCI}

\section{Combustion and Emissions ${ }^{1}$}

HCCI holds promise to increase thermal efficiency and reduce Nitrogen Oxides (NOx) and Particulate Matter (PM) emissions from internal combustion engines. Lack of a direct means to initiate the combustion and high levels of Total Hydrocarbon (THC) and Carbon Monoxide (CO) emissions are major drawbacks associated with HCCI engines. Control of combustion phasing for optimum thermal efficiency and minimizing emissions are vital for putting HCCI engines into practice. One major challenge is to develop accurate models for understanding engine performance, as those models can run real-time for HCCI control.

\footnotetext{
${ }^{1}$ The results from this chapter were presented at [1] and accepted for publication [2]. This work was done in collaboration with Mehran Bidarvatan from Michigan Technological University. Permission to use the material can be found in Appendix B.1 and B.2
} 
In this chapter, the first computationally efficient grey-box model for predicting major HCCI engine variables is developed. The grey-box model consists of a combination of physical models and three feed-forward artificial neural networks models to estimate six major HCCI variables including combustion phasing, load, exhaust gas temperature, THC, $\mathrm{CO}$, and NOx emissions. The grey-box model is experimentally validated over a large range of HCCI engines operation including 309 steady state and transient test conditions. The validation results show that the grey-box model is able to predict the $\mathrm{HCCI}$ engine outputs with average relative errors less than $10 \%$. Performance of the grey-box methodology is tested for two different HCCI engines and the verification results show that the developed six-output grey-box model can be successfully used for performance modeling of different HCCI engine applications.

\subsection{Introduction}

HCCI is a low temperature combustion mode that holds promise to obtain thermal efficiency as high as 50\% [43], reduce Nitrogen Oxides (NOx), and produce negligible Particulate Matter (PM) emissions [44]. HCCI combustion is a complicated thermo-kinetic process due to its high dependence on the mixture charge properties and the thermo-kinetic reactions, while it lacks the direct means to start the combustion process [45]. This makes the control of HCCI combustion phasing challenging. Limited operating range (i.e. engine load) and high levels of Total Unburned Hydrocarbon (THC) and Carbon Monoxide 
(CO) emissions are two other major challenges in HCCI engine [46]. In addition, HCCI engines typically run at low exhaust temperature (as low as $120^{\circ} \mathrm{C}[46]$ ) that significantly limits THC and $\mathrm{CO}$ abatement by oxidation catalysts. Therefore, reducing THC and CO emissions is more challenging for HCCI engines which shows the necessity of exhaust gas temperature control. Overall, major HCCI control objectives include combustion phasing, engine load (i.e., Indicated Mean Effective Pressure, IMEP), exhaust gas temperature, and exhaust emissions. To overcome the major HCCI challenges, simultaneous control of these engine variables is essential. This study develops a grey-box model for predicting these engine variables for performance study and control of HCCI engines.

HCCI control models can be divided into three main groups as shown in Figure 3.1. These groups include empirical or black-box models, physics-based models, and grey-box models. The first group includes System Identification (SYID) based models [47-50] and Artificial Neural Networks (ANN) models. ANN models have been widely used in internal combustion engine applications [51-57]. [58-62] are examples of ANN models used for HCCI engine control applications. The empirical models can be used to capture the behavior of HCCI engines without enough knowledge of the physics of the processes. However, due to the lack of physical knowledge, the empirical models will not be able to compensate easily for the system dynamics change in response to parametric variations. The second group includes physical models that capture characteristics of HCCI operation by using mathematical modeling of the engine cycle. [63-79] are examples of this group. 


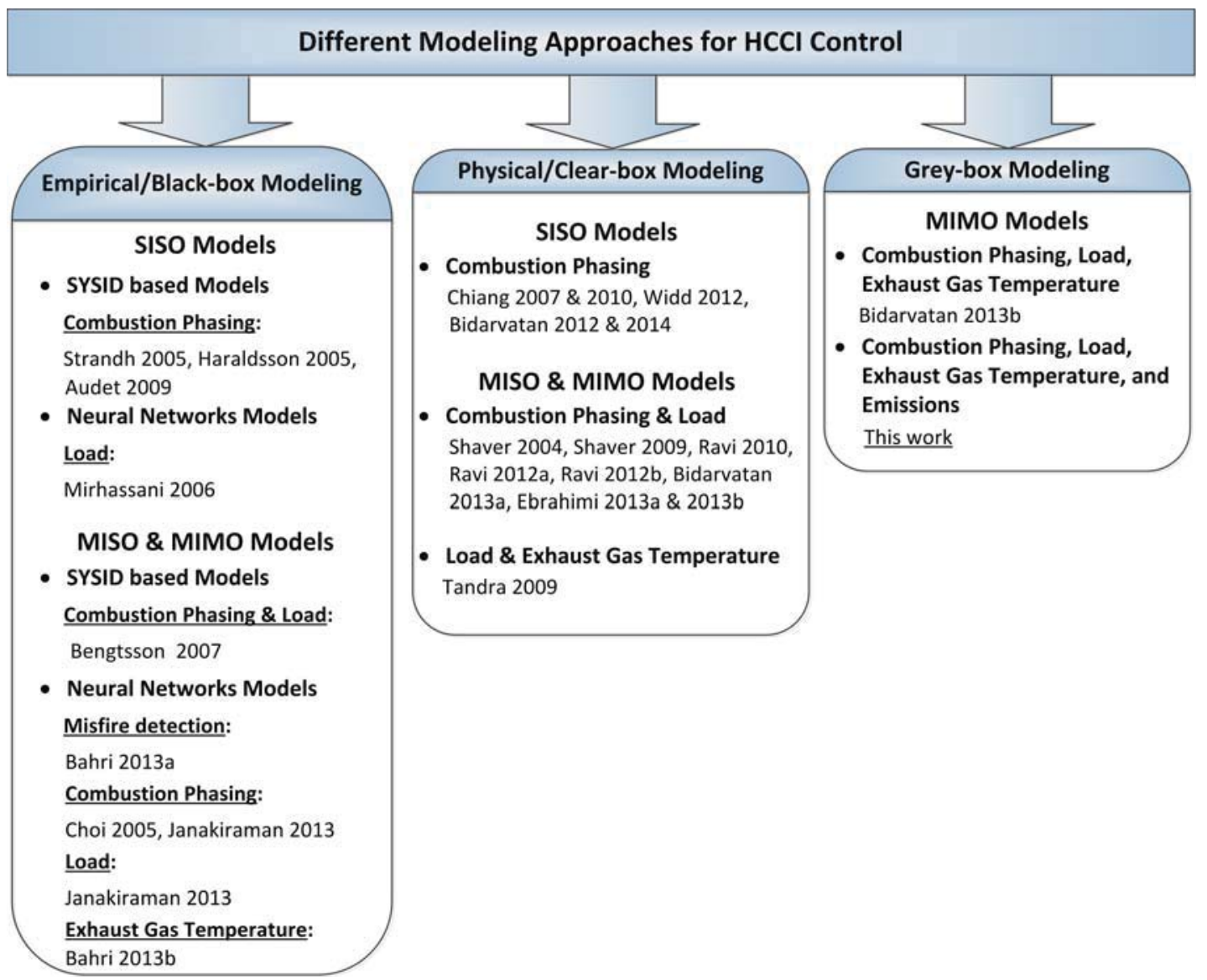

Figure 3.1: Background of HCCI engine control modeling in literature $[1,2]$.

Depending on the level of complexity, there is a variety of physical HCCI models ranging from detailed thermo-kinetic models [78] and multi-zone models $[79,80]$ to simple physics-based control-oriented models [63-77]. All of these model types can capture physical parametric changes due to their physical understanding of the system process. However, there is a limitation for real-time control application of the physical models particularly when low order computationally efficient models are required. Grey-box models [81] provide benefits of both groups of physical models (clear-box models) and black-box models, by combining these two model types. This thesis centers on developing 
a grey-box model to predict HCCI engine operation for performance analysis and control applications.

The HCCI models in the literature can be categorized into three groups with respect to the number of inputs and outputs as depicted in Figure 3.1. Single Input Single Output (SISO), Multi Input Single Output (MISO), and Multi Input and Multi Output (MIMO) models constitute these groups. [47-49,63, 65-68] are examples of SISO models used for predicting combustion phasing. Another example of a SISO HCCI model is [59] in which the engine load (IMEP) is predicted. [58,60-62] are examples of MISO models for predicting combustion phasing, separate control of load and combustion phasing, detection of misfire, and predicting exhaust gas temperature, respectively. Some examples of MIMO models are [50] and [69-74] that simultaneously predict the engine combustion phasing and load. The model in [75] predicts load and exhaust gas temperature while [81] proposes a model for simultaneous prediction of combustion phasing, load, and exhaust gas temperature.

There is no comprehensive control model in the literature for predicting HCCI engine performance parameters and exhaust emissions. Available HCCI emission models in the literature are computationally expensive for use in control applications. In this study, a comprehensive grey-box MIMO model is proposed that can predict all the major HCCI engine variables including combustion phasing, load, exhaust gas temperature, and engine-out emissions of THC, $\mathrm{CO}$, and NOx. To the best of the authors' knowledge, this 
is the first study on developing a MIMO HCCI grey-box model that can predict both the engine performance parameters and the main HCCI engine emissions. Accuracy of the model is tested by experimental validation over a large operating range of two HCCI engines under 309 steady state and transient conditions.

This chapter is presented as follows. Section 3.2 describes the Ricardo HCCI engine experimental data [82] used for grey-box modeling. The structure of the grey-box model is explained in Section 3.3. Next, design of the ANN structure, training and validation results for the grey-box model are discussed in Section 3.4. This section also includes the validation of the grey-box model for a totally different HCCI engine (Yanmar).

\subsection{Experimental Data}

Experimental data from [82] for a single cylinder HCCI Ricardo engine at 208 steady state operating conditions are used in this study. The specifications of the engine are listed in Table 3.1.

Operating range of the HCCI engine is shown in Figure 3.2. For this study three different blends of Primary Reference Fuels (PRFs) are used. These fuels include PRF0 (n-heptane), PRF20 (20\% iso-Octane and 80\% n-heptane), and PRF40 (40\% iso-Octane and 60\% n-heptane). The data includes ultra-lean air-fuel mixtures with fuel equivalence ratio 


\section{Table 3.1}

Specification of Ricardo single cylinder engine.

\begin{tabular}{cc}
\hline \hline Parameter & Value (units) \\
\hline Bore & $80 \mathrm{~mm}$ \\
Stroke & $88.9 \mathrm{~mm}$ \\
Compression ratio & $10: 1$ \\
Displacement volume & $0.447 \mathrm{~L}$ \\
Number of valves & 4 \\
IVO/IVC & $-175 /+55 \mathrm{CAD} \mathrm{aBDC}$ \\
EVO/EVC & $-70 /-175 \mathrm{CAD}$ aBDC \\
\hline
\end{tabular}

ranging from 0.29 to 0.61. In addition, external Exhaust Gas Recirculation (EGR) is 0\% in this study.

Range of combustion phasing (CA50) in Figure 3.3 is from 0 to $25 \mathrm{CAD}$ aTDC, the engine load (IMEP) ranges from 3.4 to 9.1 bar, and the exhaust gas temperature $\left(T_{\text {exh }}\right)$ ranges from 242 to $386^{\circ} \mathrm{C}$. More than $40 \%$ of the data points in Figure 3.3 have $T_{\text {exh }}$ less than $300^{\circ} \mathrm{C}$. The light-off temperature (the temperature at which the catalyst becomes more than 50 percent effective) is about 250 to $300^{\circ} \mathrm{C}$ for most catalysts [83, 84]. To ensure that high THC and CO emissions in HCCI can be mitigated by an oxidation catalyst, it is important to adjust the exhaust gas temperature above the catalyst light-off temperature. In addition, it is necessary to ensure that the engine generates a minimum amount of $\mathrm{THC}$ and $\mathrm{CO}$ emissions until the catalyst reaches its fully warm-up condition. Figure 3.4 shows ranges of the engine-out harmful exhaust gas concentrations that expand from 0 to 50 PPM for NOx, $0.05 \%$ to $0.50 \%$ for CO, and 1452 to 5127 PPM for THC. The experimental data from this section is used for training and validation of the HCCI grey-box model described 
(a)

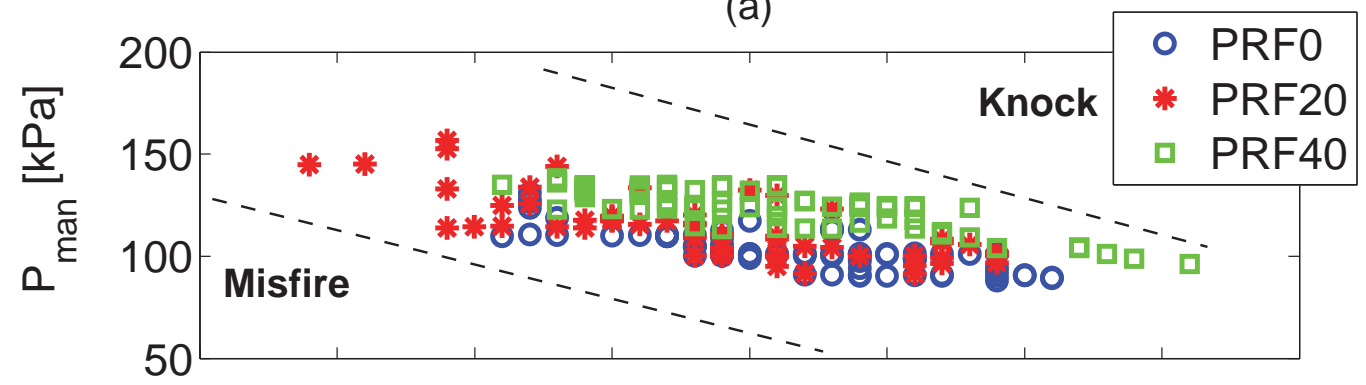

(b)

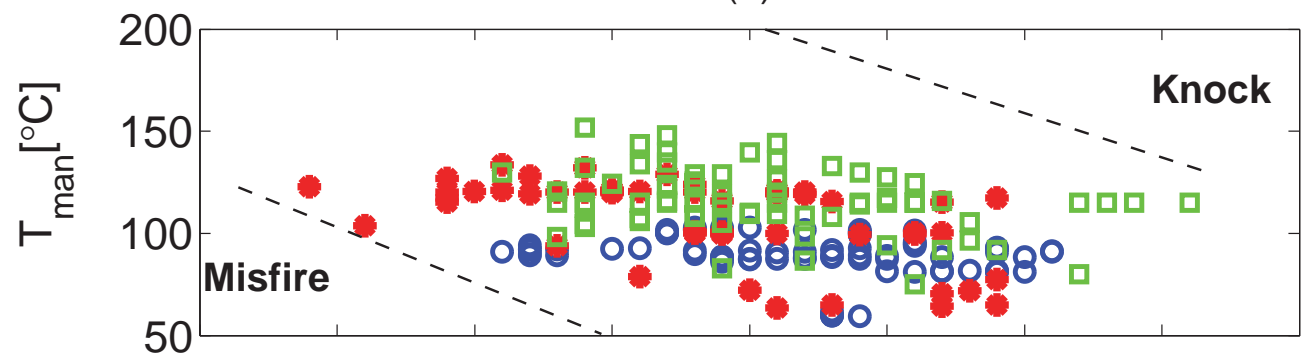

(c)

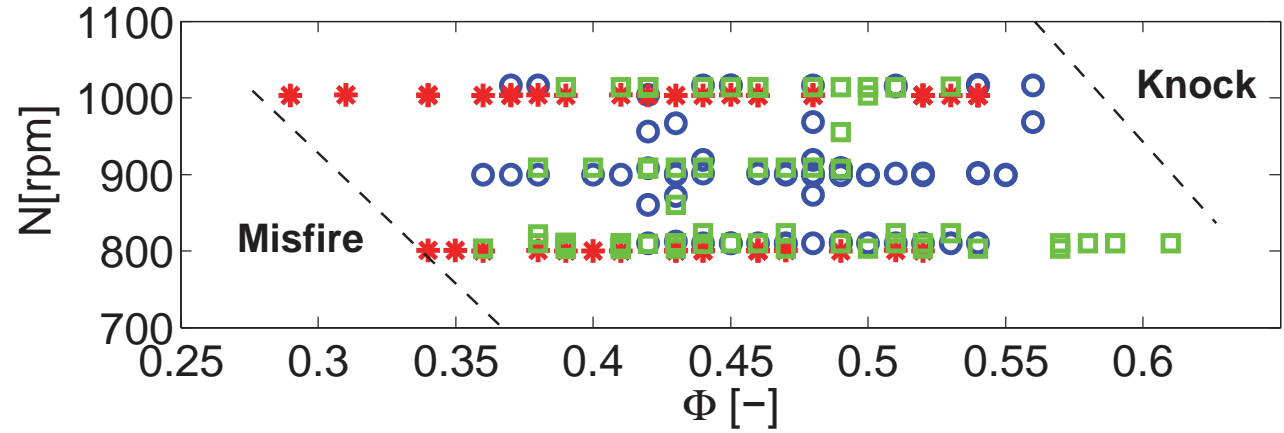

Figure 3.2: Operating range for 208 experimental HCCI data points used in this study $[1,2]$. (Ricardo engine)

in Section 3.4. 
(a)

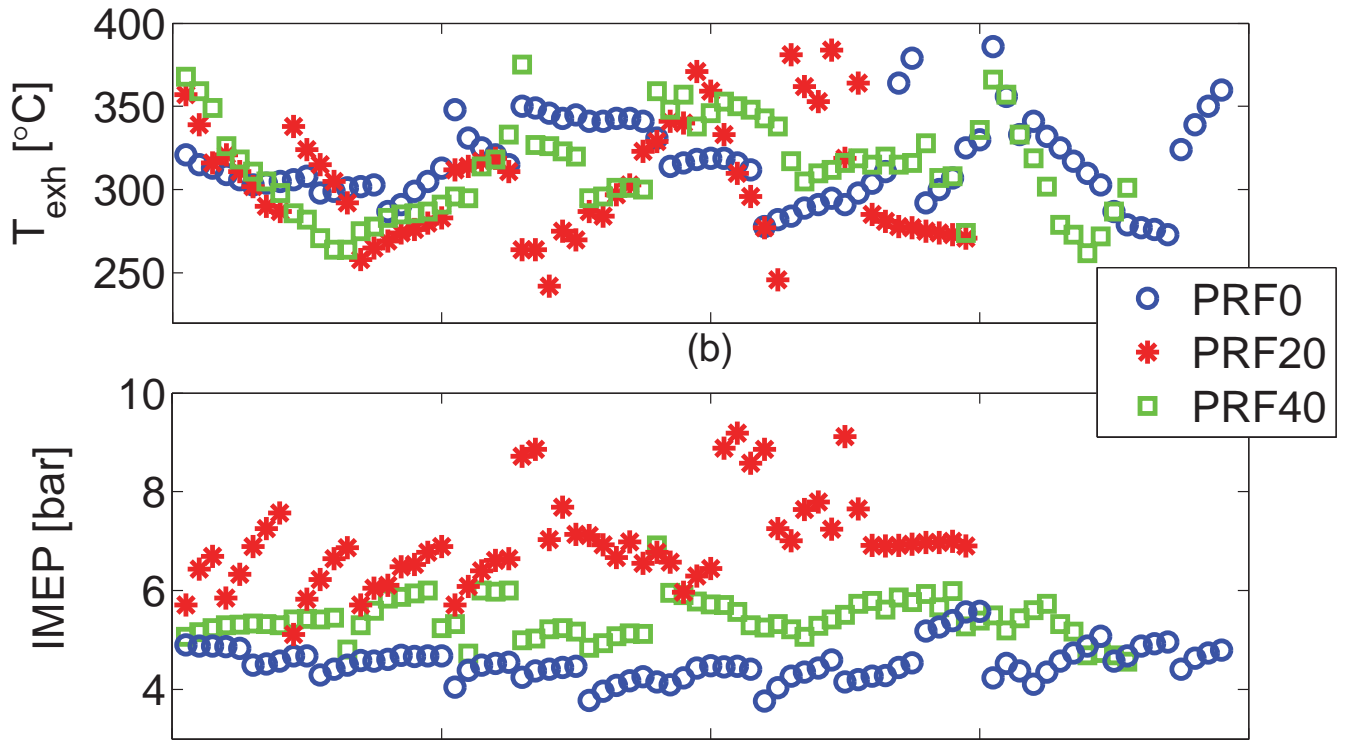

(c)

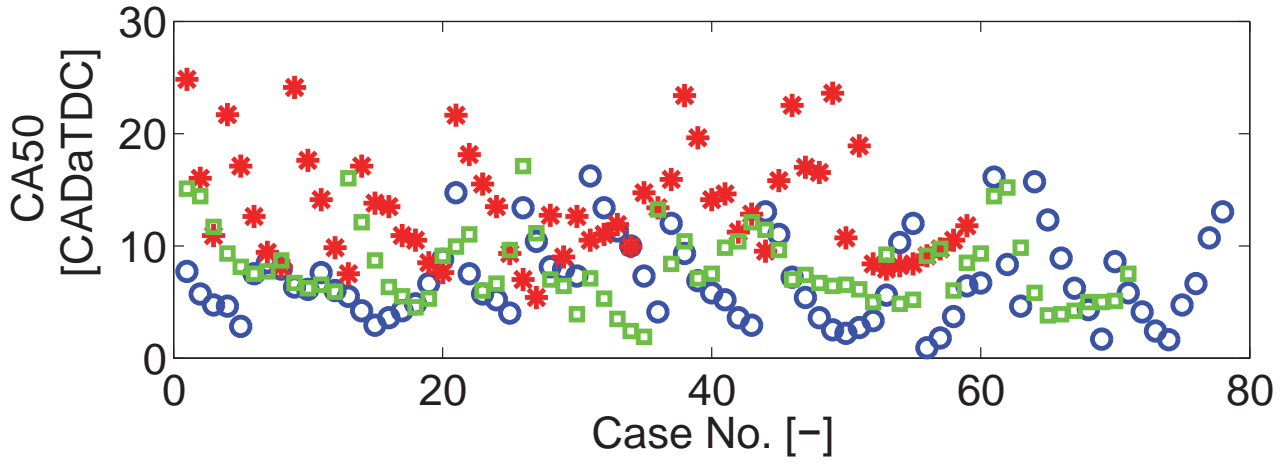

Figure 3.3: Range of engine combustion phasing (CA50), load (IMEP), and exhaust gas temperature $\left(T_{e x h}\right)$ for the experimental data points shown in Figure 3.2 [1,2]. (Ricardo engine) 
(a)

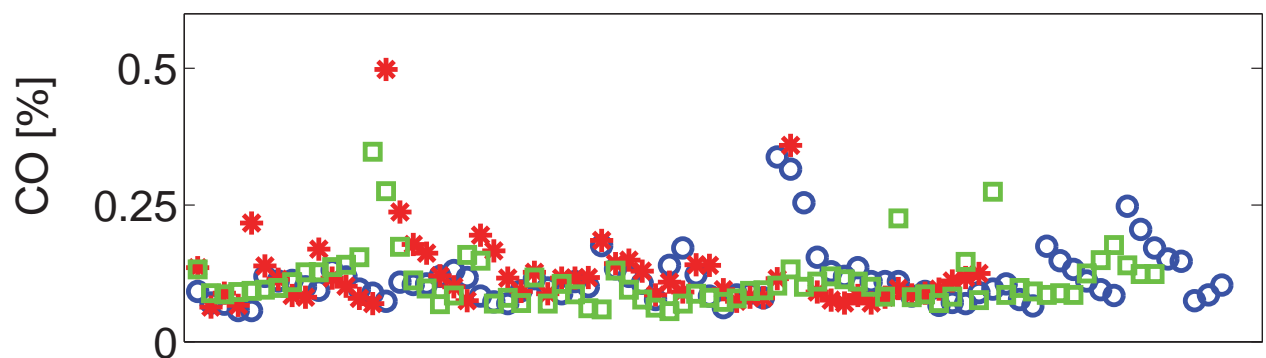

(b)

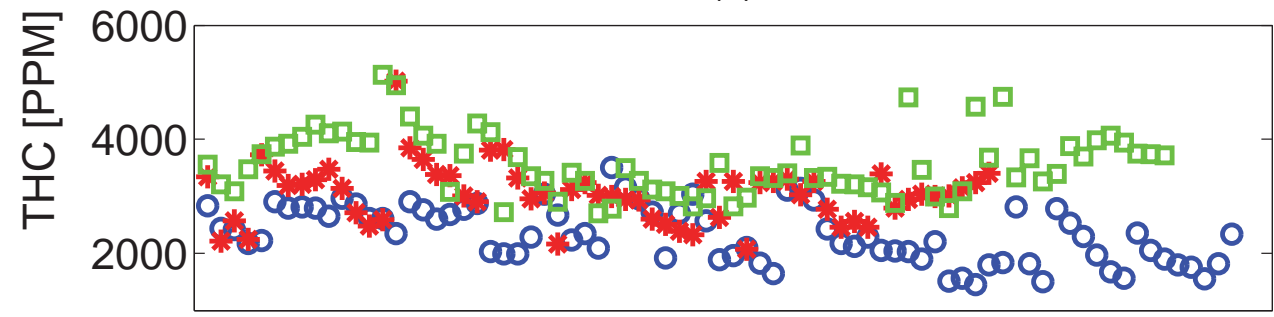

(c)

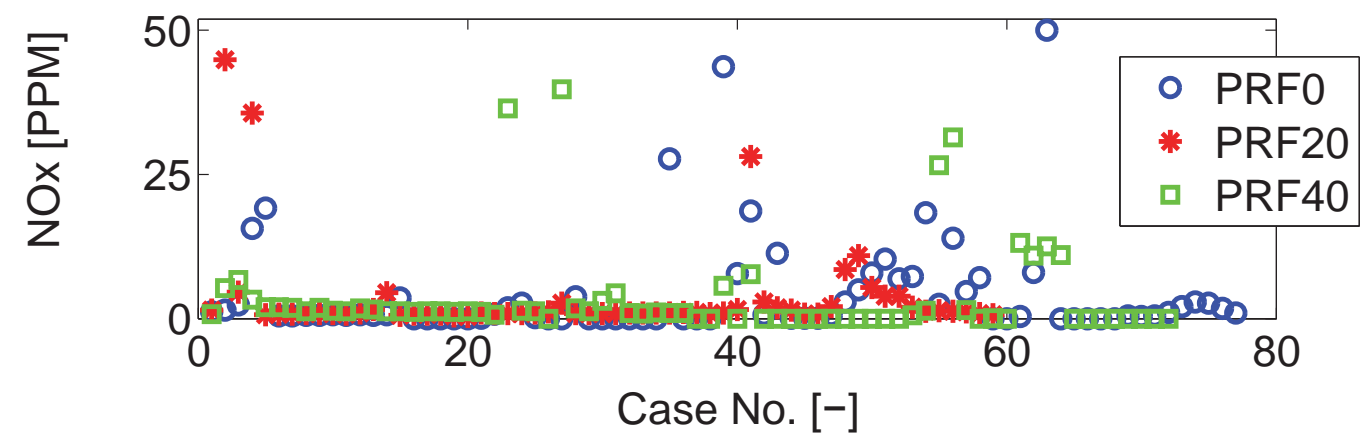

Figure 3.4: Range of engine $\mathrm{CO}, \mathrm{THC}$, and NOx exhaust gas concentrations for the experimental data points shown in Figure 3.2 [1,2]. (Ricardo engine) 


\subsection{Grey-box Model Description}

This section describes the architecture of the grey-box model used in this thesis. The section describes the constituents of the grey-box i.e. physical model, black-box model and their integration.

\subsubsection{Architecture of Model}

In this section, a grey-box model is developed using the serial architecture shown in Figure 3.5. It consists of a CA50-IMEP grey-box model, an ANN $T_{e x h}$ model, and an ANN emission model. The CA50-IMEP grey-box model consists of a physical model and an ANN CA50-IMEP model. The $T_{e x h}$ grey-box model requires five inputs including engine speed $(\mathrm{N})$, fuel equivalence ratio $(\phi)$, adiabatic flame temperature $\left(T_{a d}\right)$, and $T_{e x h}$ from the clear-box model $\left(T_{e x h p}\right)$, and CA50 from the CA50-IMEP grey-box model $\left(C A 50_{g}\right)$. The inputs to the grey-box emission model are $\phi$, intake manifold pressure $\left(P_{\operatorname{man}}\right)$, intake manifold temperature $\left(T_{m a n}\right), \mathrm{N}$, and $C A 50_{g}$. The model outputs are $\mathrm{CO}, \mathrm{THC}$, and NOx concentrations. 


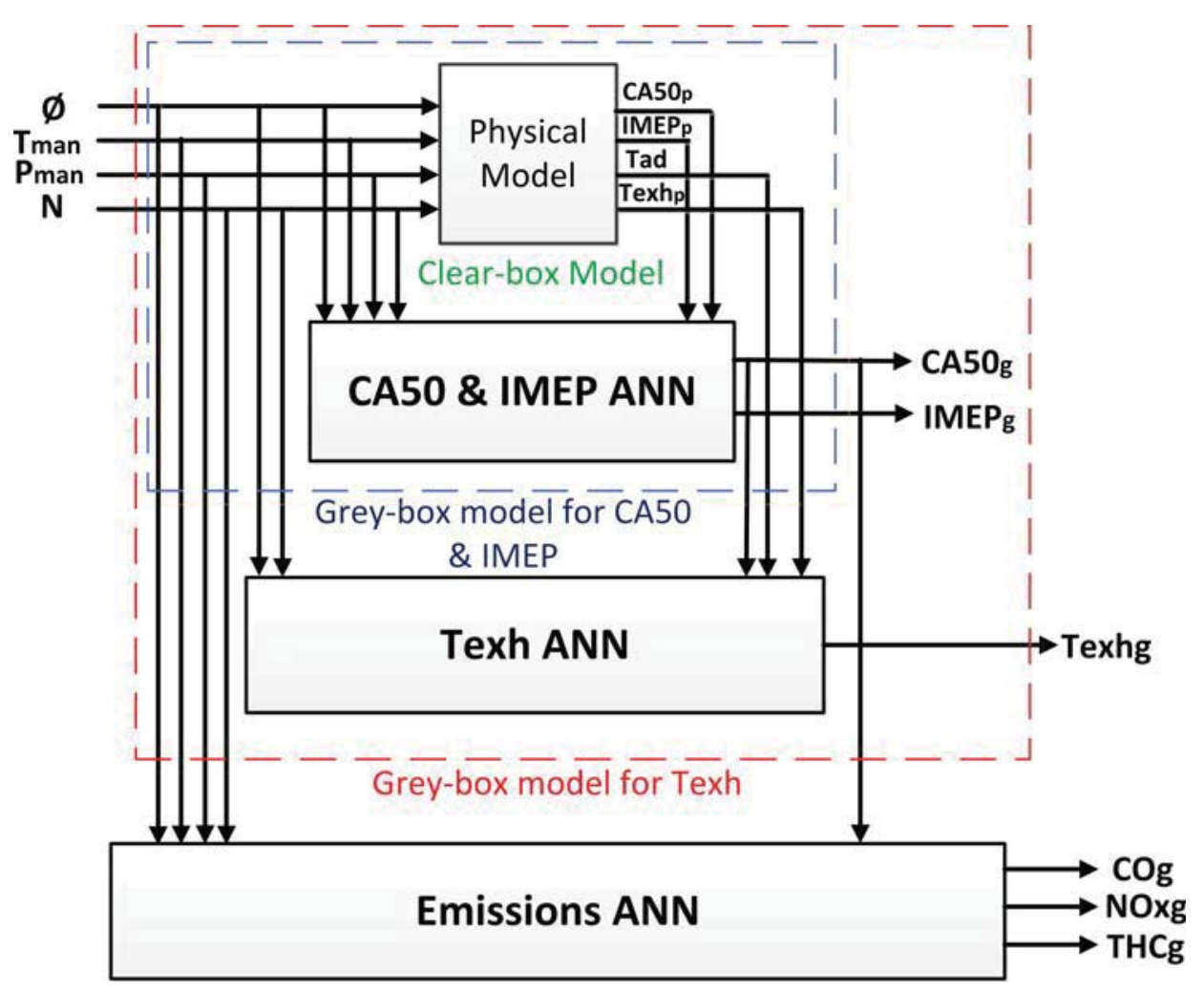

Figure 3.5: Architecture of the grey-box HCCI model [1,2].

\subsubsection{Physical Model}

The physical model in the CA50-IMEP grey-box model consists of four physical HCCI models used for predicting $C A 50_{p}$ [85], IMEP $P_{p}$ [74], adiabatic flame temperature $\left(T_{a d}\right)$, and $T_{\text {exh }}$ [86]. $T_{a d}$ is calculated at constant volume since the HCCI cycle is a closer approximation to constant volume combustion than to constant-pressure combustion. $T_{a d}$ is calculated from the ideal gas law with enthalpy of reactants and specific heat of each of the mixture components for any $\phi$ and $T_{m a n}$ of HCCI engine. Details of the physical models are shown in the Appendix A. $\phi, T_{m a n}, P_{m a n}$, and $\mathrm{N}$ are the dominant engine operating 
variables that affect CA50, IMEP, $T_{a d}$, and $T_{e x h}[82,83,85]$. Therefore, they are used as the inputs to the clear-box model. The engine operating variables including $\phi$ and $\mathrm{N}$ along with

$T_{a d}, T_{\text {exhp }}$, and $C A 50_{g}$ are used as the inputs to the $T_{\text {exh }}$ ANN model ( $T_{\text {exh }}$ is the output). The emissions ANN model receives all the aforementioned engine operating variables and $C A 50_{g}$ to predict the engine-out emissions $\left(C O_{g}, T H C_{g}\right.$, and $\left.N O x_{g}\right)$. No EGR is used in this study, thus it is not among the model inputs.

\subsubsection{Artificial (Black-Box) Model}

Structure of the CA50-IMEP, $T_{e x h}$, and emissions ANN models are shown in Figures 3.6, 3.7 and 3.8 respectively. A hyperbolic tangent sigmoid function is used as the activation function for the hidden and output layers. The back-propagation learning algorithm [87] is used for training the ANN models. The weights are initially chosen randomly. Then, they are adjusted during several training iterations to minimize a cost function chosen to be the Mean Squared Error (MSE) [87]. The ANN is simulated with the input data and the error is calculated between the estimated output and the actual output. The weights are then updated starting with the output weights and progressing back to the input weights using a gradient descent to minimize the MSE. The process is repeated until a performance goal is achieved. Training is done only for the black-box models; the physical model is run and its outputs are used as the inputs to the black-box models for either training or validation. Therefore, there is no training for the physical parts of the grey-box model. 
The term black-box only model in this study refers to an independent ANN model with inputs only from the engine operating conditions including $\phi, T_{\operatorname{man}}, P_{\operatorname{man}}$, and $\mathrm{N}$. The black-box only model is not part of the grey-box model structure (Figure 3.5) and does not have any inputs from the physical model.

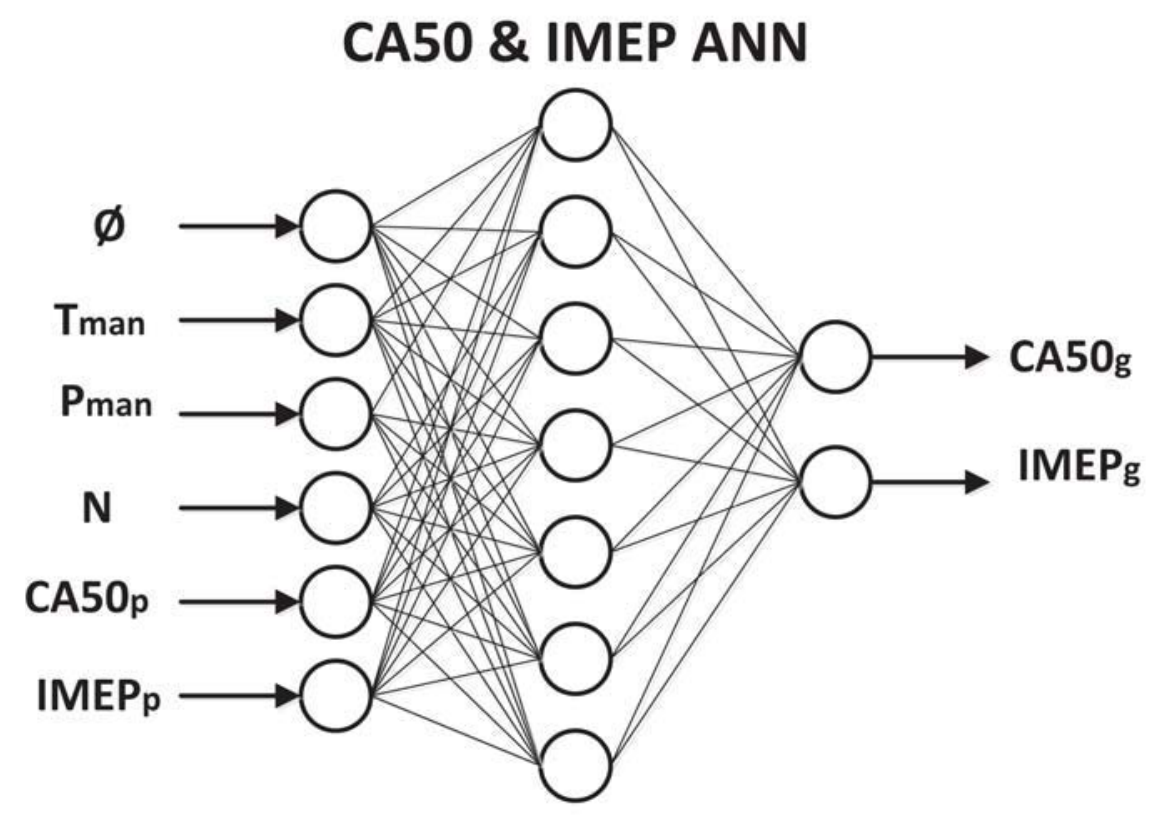

Figure 3.6: Feedfoward Artificial Neural Networks (ANN) for CA50 and IMEP used in this study [1,2]. 


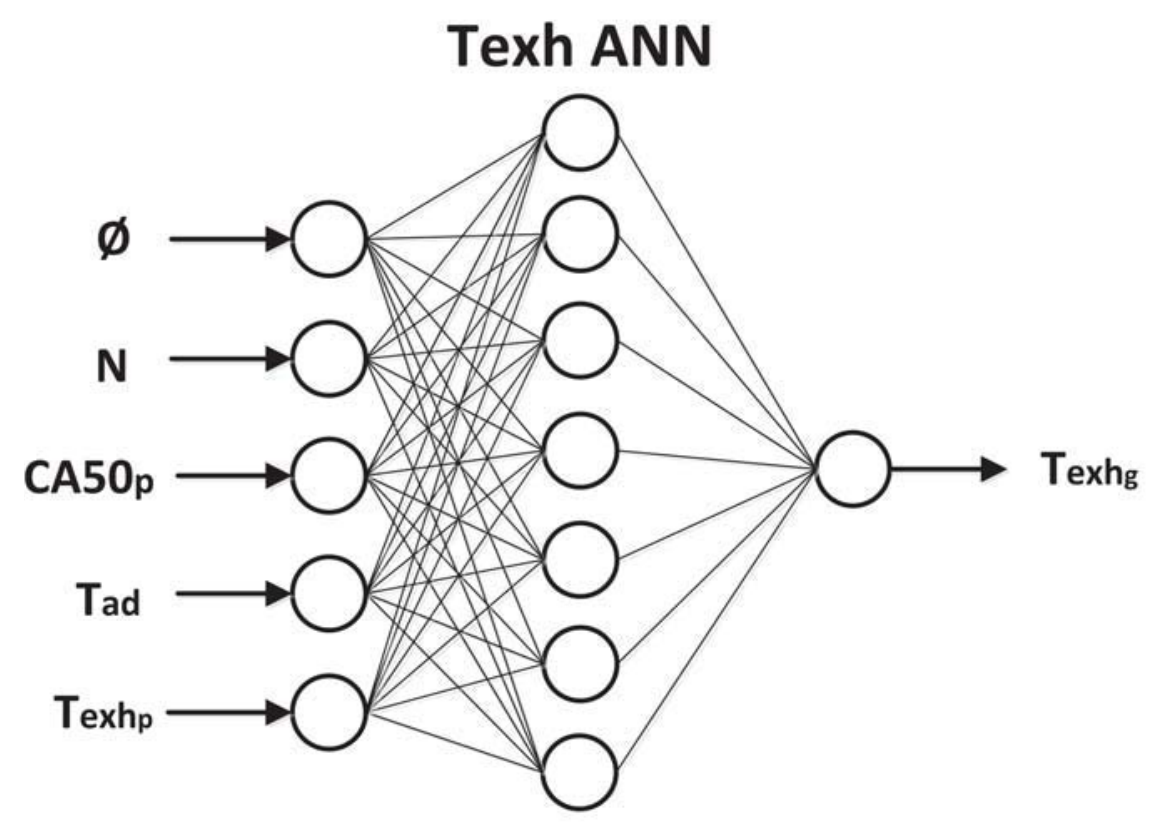

Figure 3.7: Feedfoward Artificial Neural Networks (ANN) for $T_{\text {exh }}$ used in this study $[1,2]$. 


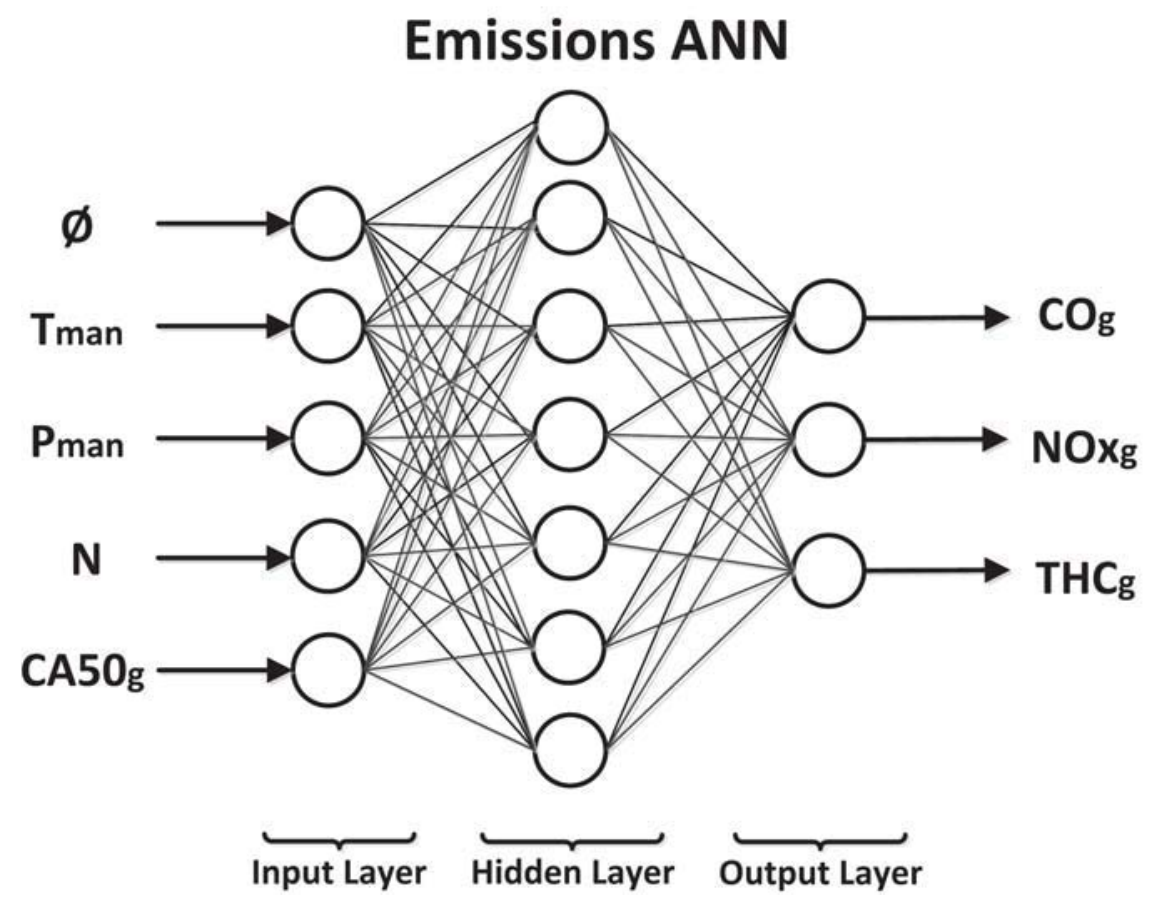

Figure 3.8: Feedfoward Artificial Neural Networks (ANN) for emissions used in this study $[1,2]$. 


\subsection{Results and Discussion}

The CA50-IMEP, $T_{\text {exh }}$, and emissions ANN models are trained and validated in this section for different PRFs (i.e. PRF0, PRF20, and PRF40) from Ricardo HCCI engine. Then, performance of the developed grey-box models are tested on a different HCCI engine (Yanmar).

\subsubsection{ANN Structure Design}

To design the ANN structure, it is necessary to determine the optimum size of the ANN model and the optimum number of epochs (training iterations) to avoid overtraining. For this purpose, in this section the design procedure is illustrated for the CA50-IMEP ANN model, while the same procedure is used for $T_{\text {exh }}$ and emission ANN models. An ANN with one hidden layer and 25 neurons is selected for the CA50-IMEP model. The number of neurons in the hidden layer is chosen by investigating the training performance as shown in Figure 3.9. For every PRF, the ANN is trained and validated over a range of 1 to 35 hidden neurons (Figure 3.9).

As the number of neurons increases, the MSE decreases and the coefficient of correlation increases. After 25 neurons in the hidden layer, the change in prediction accuracy of the 
(a) PRF0

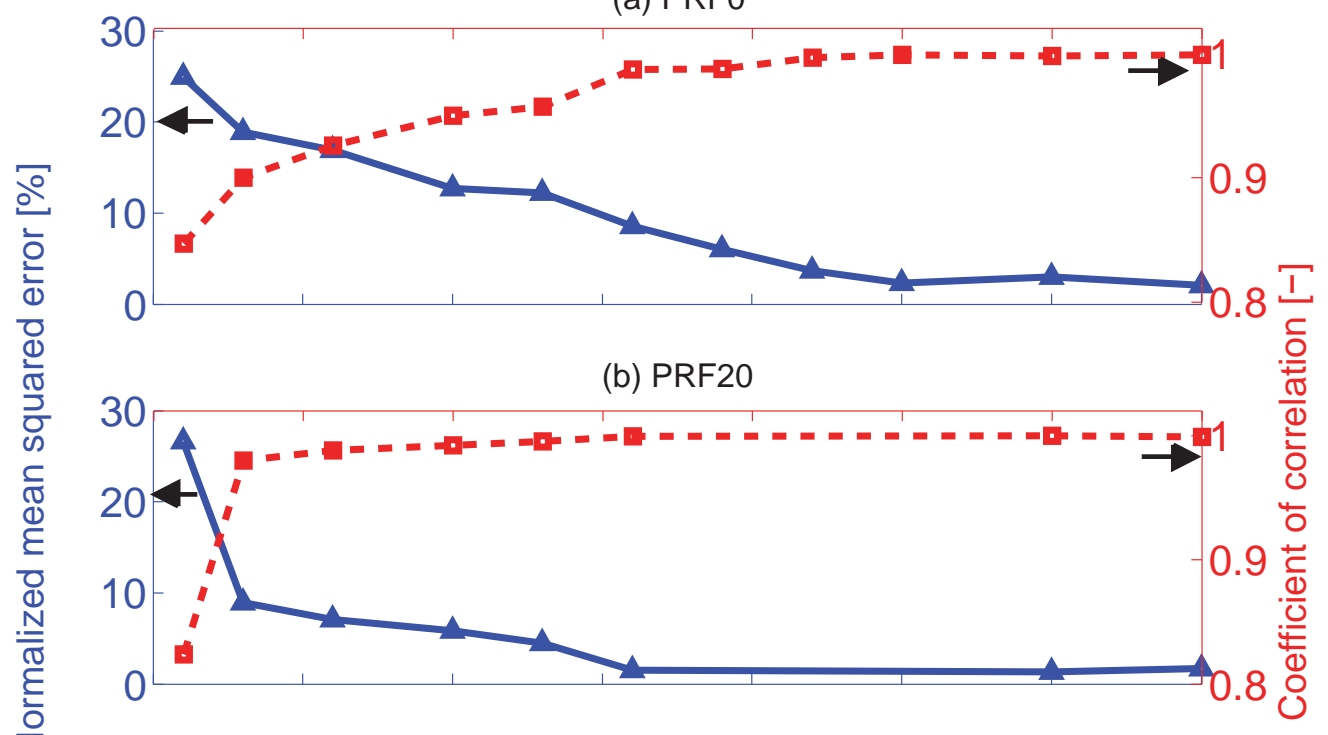

(c) PRF40

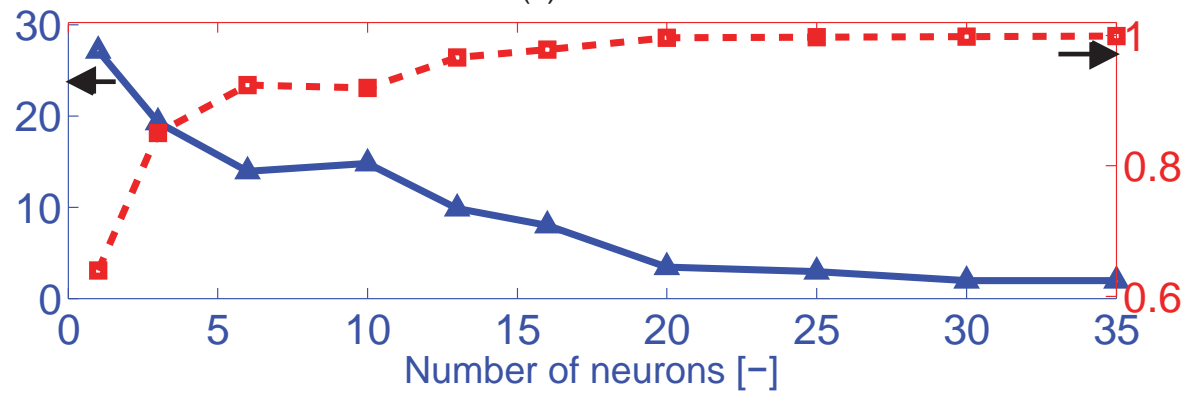

Figure 3.9: Training metrics for the CA50-IMEP ANN model. Normalized MSE in the $y$-axis is the average of normalized MSE for CA50 and IMEP $[1,2]$.

model is minor with increase in the complexity of the network. This helps in choosing the smallest network size with an acceptable accuracy. A size of 25 neurons in the hidden layer is selected to satisfy a trade-off between the model complexity and accuracy.

The CA50-IMEP ANN model is simulated to find the optimum number of epochs to avoid overtraining. The results are shown in Figure 3.10. Initially, the MSE decreases 


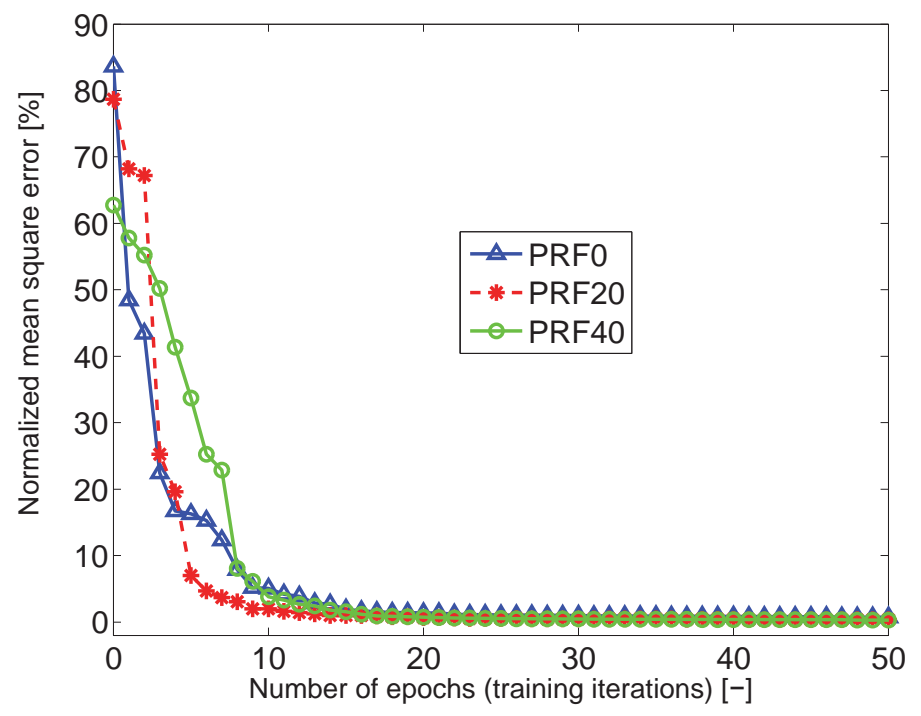

Figure 3.10: Training MSE over iteration history for the CA50-IMEP ANN model. Normalized MSE in the y-axis is the average of normalized MSE for CA50 and IMEP $[1,2]$.

dramatically with increasing the number of epochs, but then the drop in MSE becomes small and the MSE stays at about a constant value. Optimum number of training iterations is found to be 30, as shown in Figure 3.10.

208 steady-state data points of the Ricardo HCCI engine for three PRFs are used. $75 \%$ of the data is used for training while the rest $25 \%$ of the data is used to validate the grey-box models. The training and validation results are discussed in the following Sections 3.4.2 to 3.4 .5 . 


\subsubsection{Combustion Phasing and Engine Load (IMEP)}

Results of training and validation of the CA50-IMEP grey-box model are shown in Figures 3.11 and 3.12. The accuracy of the grey-box model for predicting CA50 and IMEP is compared with those from the clear-box and the black-box models in Table 3.2. The grey-box model shows the best performance in predicting CA50 and IMEP among all the studied types of modeling. Root Mean Squared Error (RMSE) of the grey-box model is 3.3 and 2.1 CAD less compared to the clear-box and black-box models, respectively. In addition, Standard Deviation (STD) of error for the grey-box model is about 2.3 and 2.1 CAD less than the clear-box and black-box models, respectively. Similarly, the IMEP prediction of the grey-box model is better than those of its two peers with more than $80 \%$ and $60 \%$ reduction in RMSE and about $94 \%$ and $86 \%$ reduction in STD of error compared to the clear-box and black-box models, respectively. 


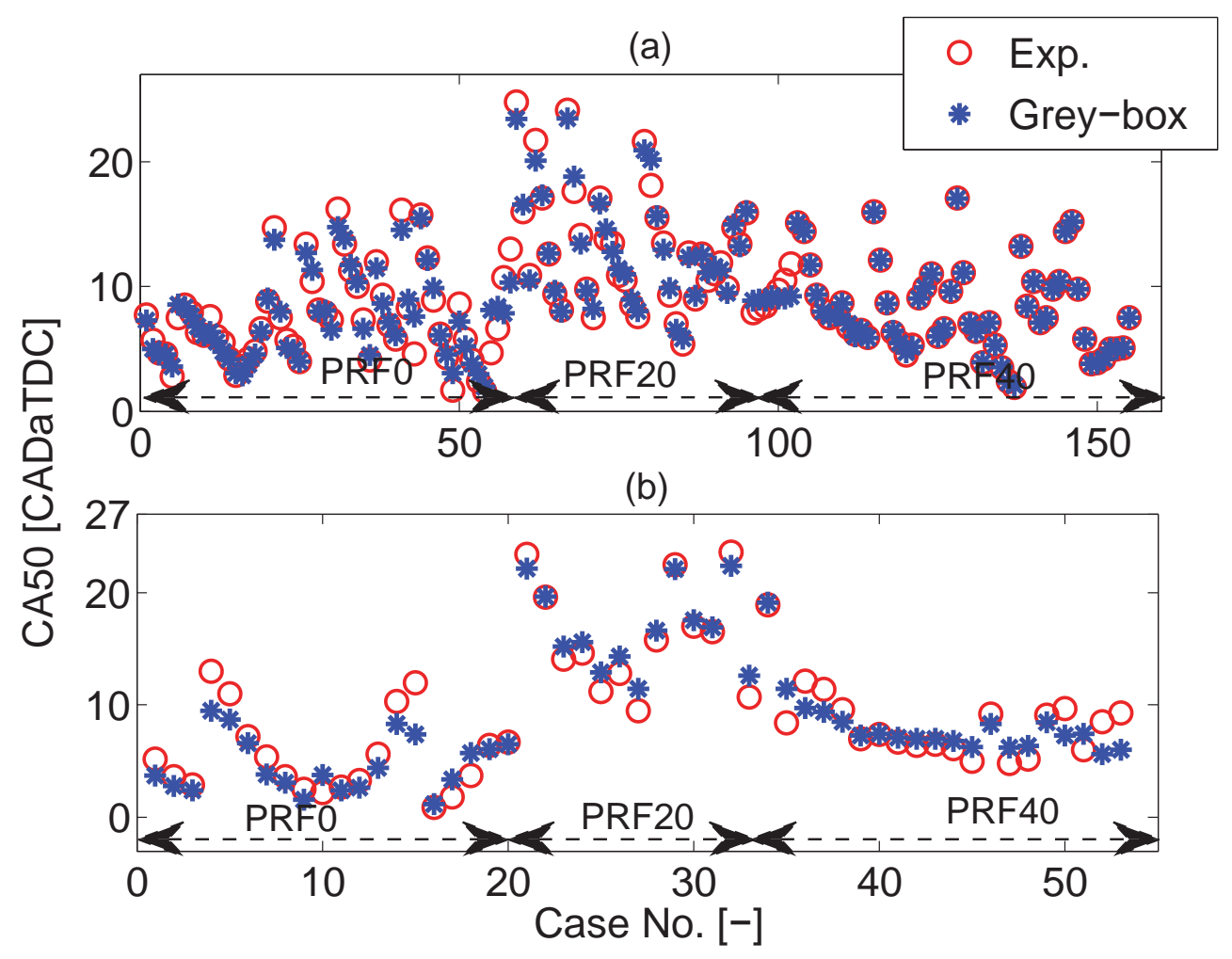

Figure 3.11: Prediction of CA50 for Ricardo engine: (a) training, (b) validation data $[1,2]$. 


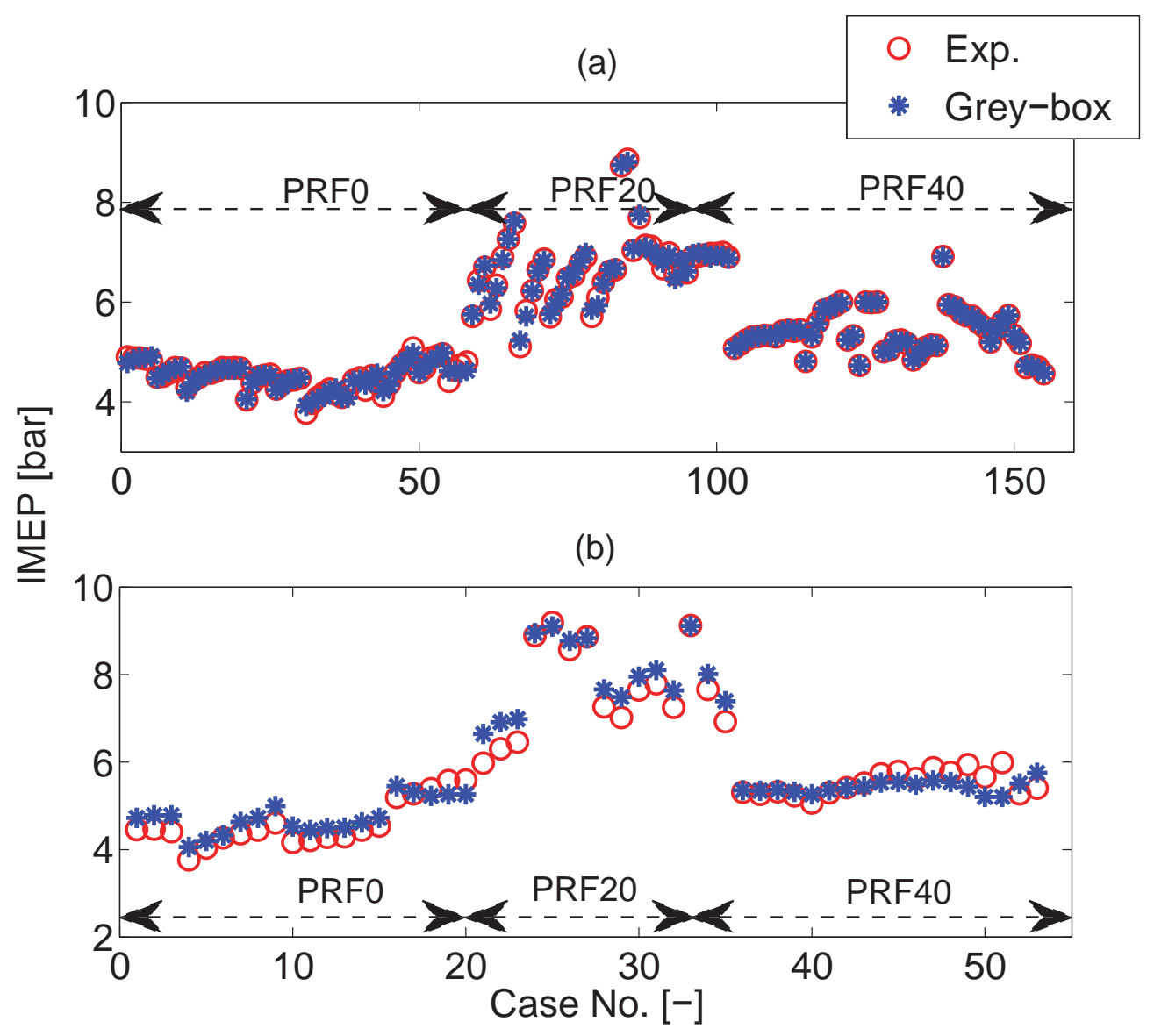

Figure 3.12: Prediction of IMEP for Ricardo engine: (a) training, (b) validation data $[1,2]$. 
Table 3.2

Comparison of average accuracy of the clear-box, black-box, and the grey-box models for all fuels for Ricardo engine [1,2].

\begin{tabular}{cccc}
\hline \hline Type of Model & Parameter & STD of Error & RMSE \\
\hline & CA50 [CAD] & 3.1 & 4.1 \\
& IMEP [bar] & 1.7 & 1.30 \\
& Texh [ $\left.{ }^{\circ} \mathrm{C}\right]$ & 17.0 & 21.0 \\
Clear-box & NOx [PPM] & - & - \\
& CO [\%] & - & - \\
& THC [PPM] & - & - \\
& & & \\
& CA50 [CAD] & 2.9 & 2.9 \\
& IMEP [bar] & 0.7 & 0.50 \\
Black-box only & Texh [ $\left.{ }^{\circ} \mathrm{C}\right]$ & 10.0 & 13.3 \\
& NOx [PPM] & 11 & 12 \\
& CO [\%] & 0.14 & 0.18 \\
& THC [PPM] & 1054 & 1210 \\
& CA50 [CAD] & & \\
& IMEP [bar] & 0.8 & 0.8 \\
Grey-box & Texh [ $\left.{ }^{\circ} \mathrm{C}\right]$ & 0.1 & 0.20 \\
& NOx [PPM] & 5.0 & 5.3 \\
& CO [\%] & 4 & 4 \\
& THC [PPM] & 0.03 & 0.03 \\
\hline
\end{tabular}




\subsubsection{Exhaust Gas Temperature}

Performance of the $T_{e x h}$ grey-box model is shown in Figure 3.13. Table 3.2 compares the average of RMSE and STD of error for all the three PRFs. It shows that there are about $16,8{ }^{\circ} \mathrm{C}$ reductions in RMSE and $12,5{ }^{\circ} \mathrm{C}$ reductions in STD of error in the grey-box model prediction of $T_{e x h}$ compared to the clear-box and the black-box models, respectively.

Overall, the $T_{e x h}$ grey-box model outperforms its two clear-box and black-box peers.

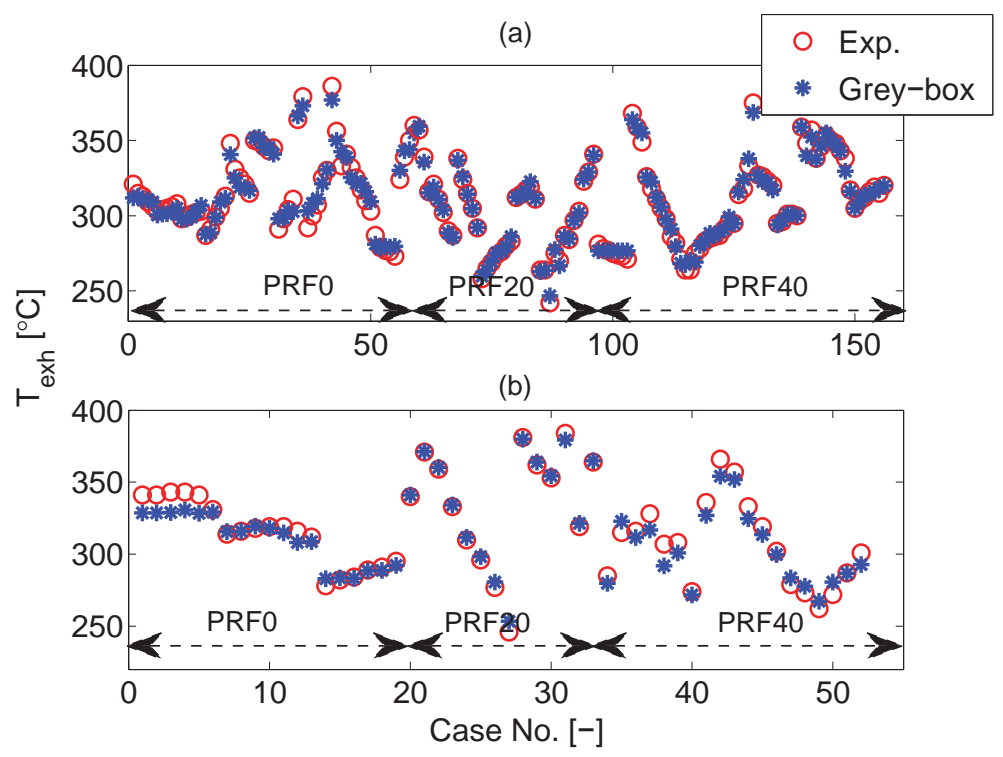

Figure 3.13: Prediction of $T_{\text {exh }}$ (exhaust gas temperature) for Ricardo engine: (a) training, (b) validation data $[1,2]$. 


\subsubsection{Engine-out Emissions}

Performance of the grey-box model in predicting the engine-out emissions concentrations are shown in Figures 3.14, 3.15, and 3.16 and indicate the grey-box model can effectively predict concentrations of all the three types of emissions with correct trends and acceptable accuracy. Comparison results in Table 3.2 show that the prediction of CO, THC, and NOx emissions have been improved by more than three times using the grey-box emission model compared to the black-box model.

(a)

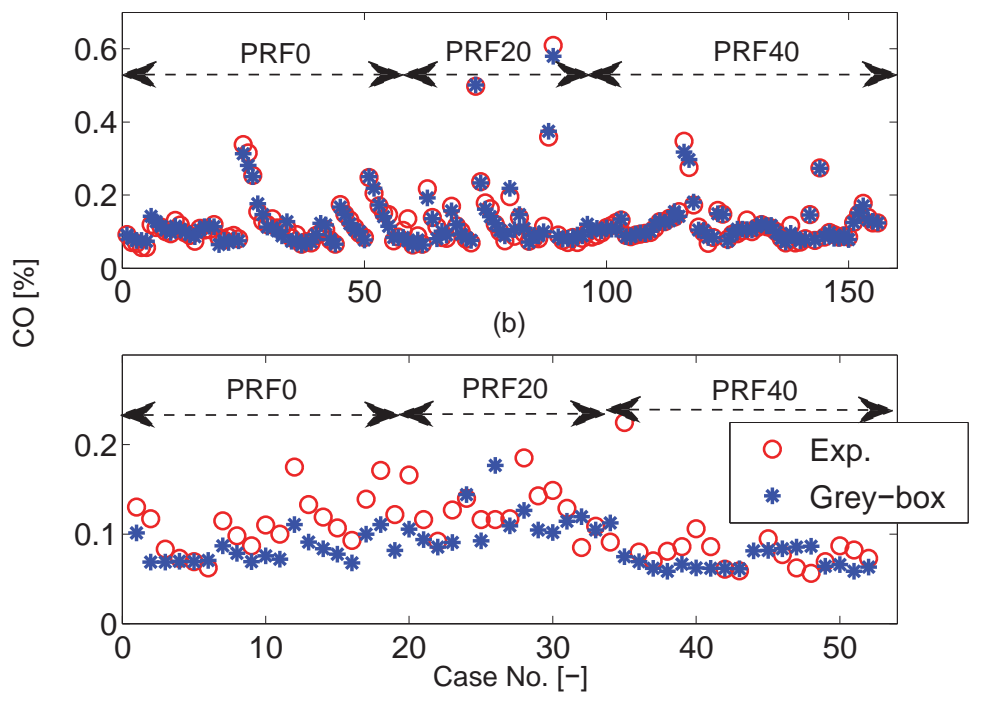

Figure 3.14: Prediction of $\mathrm{CO}$ concentration for Ricardo engine: (a) training, (b) validation data [1,2]. 


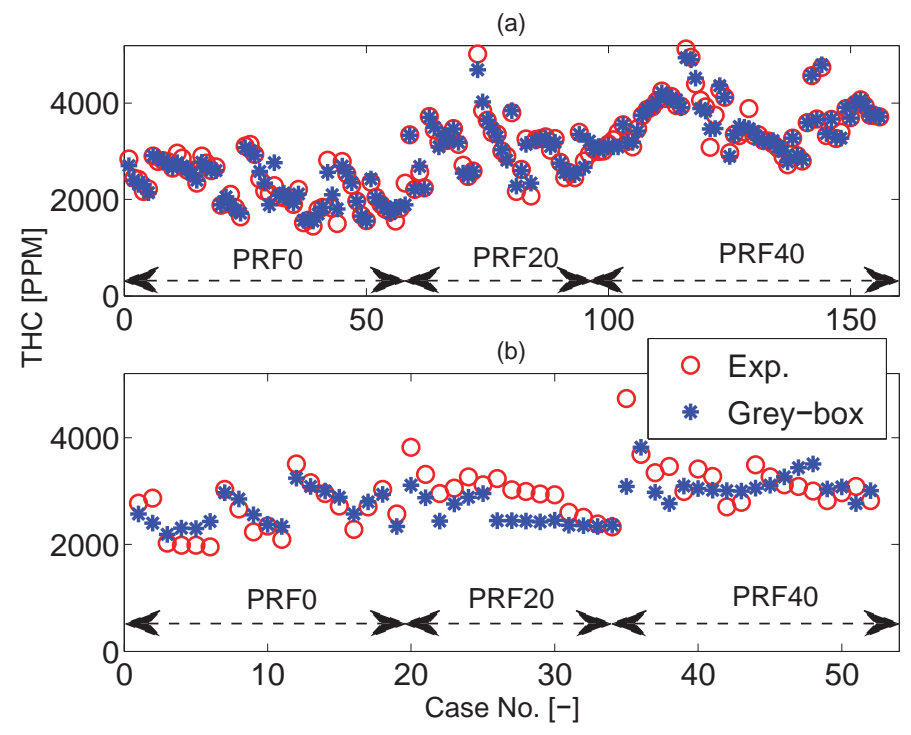

Figure 3.15: Prediction of THC concentration for Ricardo engine: (a) training, (b) validation data $[1,2]$.

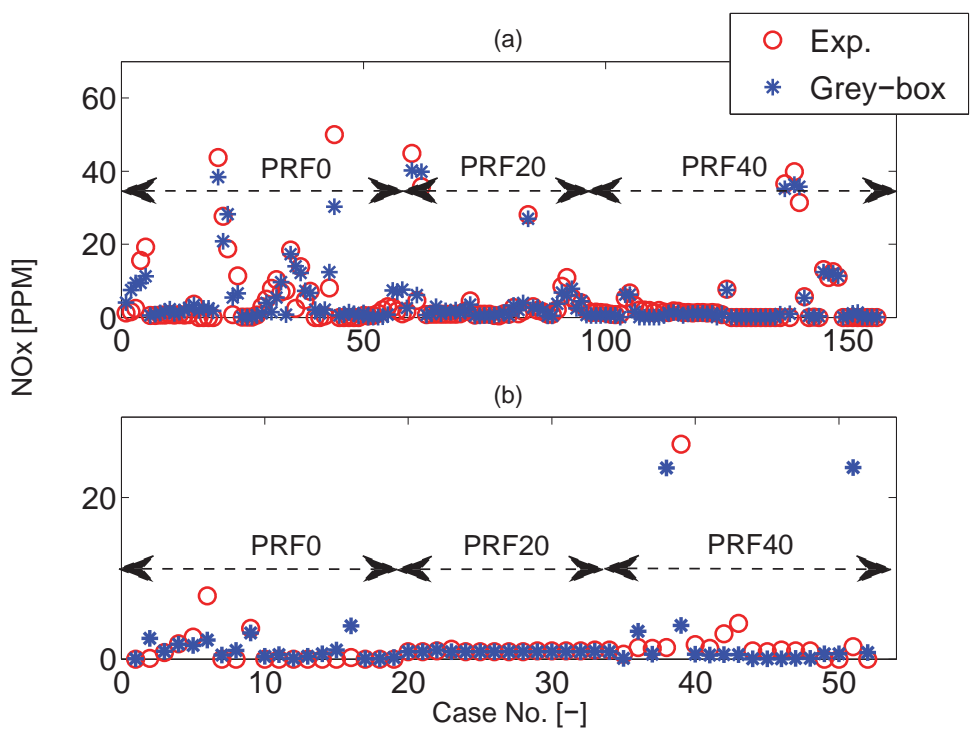

Figure 3.16: Prediction of NOx concentration for Ricardo engine: (a) training, (b) validation data $[1,2]$. 


\subsubsection{Transient Validation}

The grey-box models are also validated against the transient HCCI experimental data taken from [86]. The transient validation includes CA50, IMEP, and $T_{\text {exh }}$ but does not include engine-out emissions since fast response emission analyzers were not at our disposal. Transient validation results for CA50, IMEP, and $T_{\text {exh }}$ are shown in Figure 3.17. Accuracy metrics of the grey-box models for this transient operation are listed in Table 3.3 and show that the grey-box model can predict CA50 with the STD of error and RMSE of both less than 2 CAD. While both the STD of error and RMSE for IMEP and $T_{\text {exh }}$ are less than 0.1 bar and $4{ }^{\circ} \mathrm{C}$, respectively.

Computation time for the grey-box model for each engine cycle on a $3.2 \mathrm{GHz}$ Intel processor is less than $1 \mathrm{~ms}$. This makes the grey-box model desirable for model-based real time control of HCCI engines.

Table 3.3

Prediction accuracy metrics for transient validation of the CA50-IMEP and $T_{\text {exh }}$ grey-box models for Ricardo engine $[1,2]$.

\begin{tabular}{ccc}
\hline \hline Parameter & STD of Error & RMSE \\
\hline CA50 (CAD) & 1.5 & 1.6 \\
IMEP $($ bar $)$ & 0.1 & 0.085 \\
$T_{\text {exh }}\left({ }^{\circ} \mathrm{C}\right)$ & 3.1 & 4.0 \\
\hline
\end{tabular}



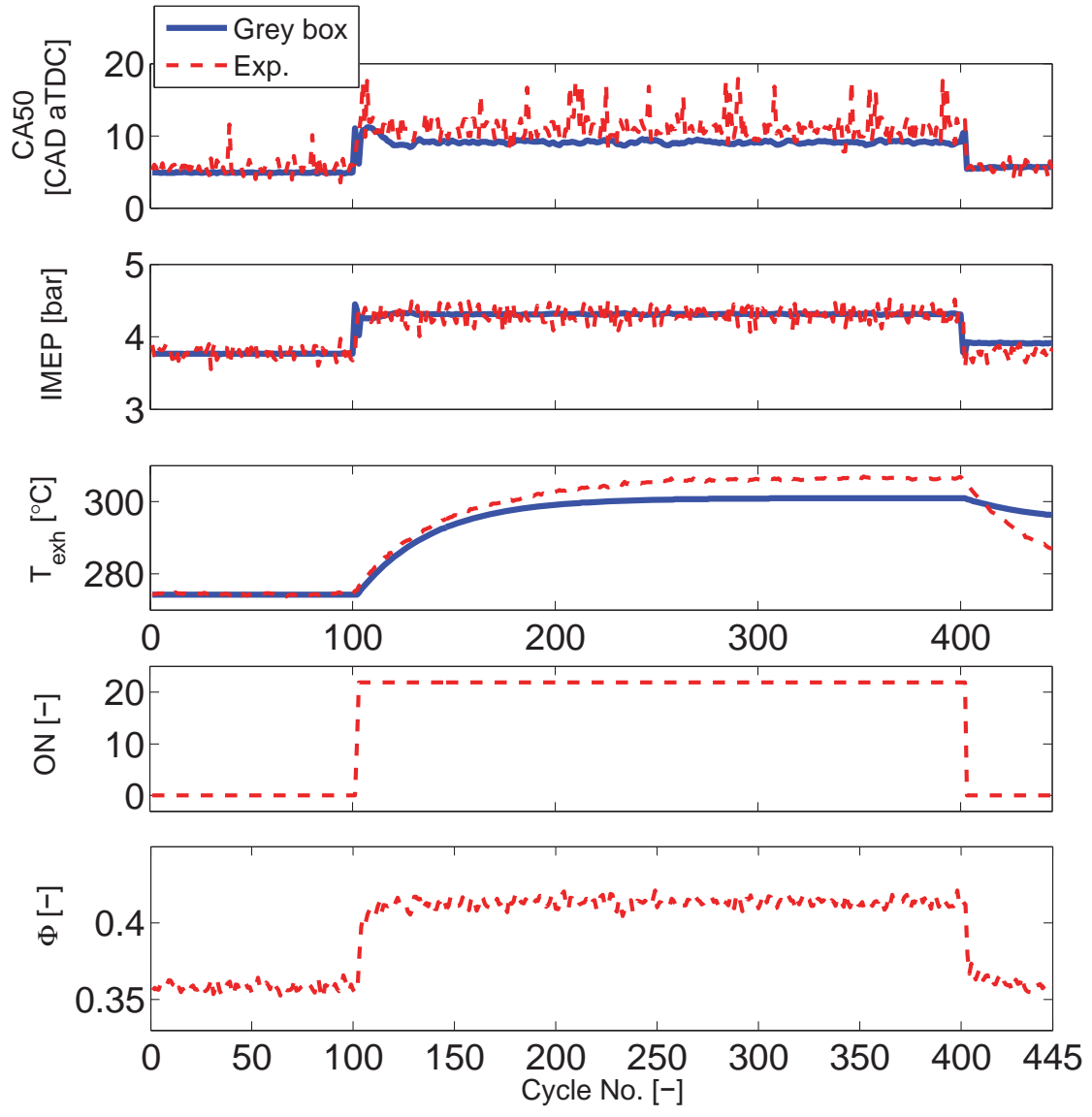

Figure 3.17: Validation of the CA50-IMEP, $T_{\text {exh }}$ grey-box models for transient fueling conditions in Ricardo engine $\left(P_{m}=110 \mathrm{kPa}, T_{m}=91 \mathrm{C}\right.$, External EGR $\left.=0 \%, P_{e x h}=99 \mathrm{kPa}, \mathrm{N}=815 \mathrm{rpm}\right)[1,2]$. 


\subsubsection{Validation on a Different HCCI Engine (Yanmar)}

The developed grey-box models are also validated for a different HCCI engine. The engine is a single-cylinder four-stroke naturally aspirated, air-cooled Yanmar diesel engine with direct injection capability that was modified for HCCI operation using ethanol fuel. The specifications of this Yanmar engine are listed in Table 3.4. Experimental data for 100 steady state operating conditions from $[61,62]$ is used in this study.

Table 3.4

Specifications of single cylinder Yanmar L70AE engine $[1,2]$.

\begin{tabular}{cc}
\hline \hline Parameter & Value (units) \\
\hline Bore & $78 \mathrm{~mm}$ \\
Stroke & $62 \mathrm{~mm}$ \\
Compression Ratio & $19.5: 1$ \\
Displacement Volume & $0.296 \mathrm{~L}$ \\
Number of Valves & 2 \\
IVO/IVC & $-155 /+59$ CAD aBDC \\
EVO/EVC & $-59 /-155$ CAD aBDC \\
\hline
\end{tabular}

The Yanmar engine experimental data are shown in Figure 3.18. It covers a large range of operating conditions (CA50 $=3$ to $16 \mathrm{CAD}$ aTDC, IMEP $=0.41$ to $3.1 \mathrm{bar}$, and $T_{\text {exh }}=163$ to $\left.260{ }^{\circ} \mathrm{C}\right)$. The air-fuel mixture used in this engine is lean $(\phi=0.23$ to 0.35$)$ to avoid knock occurrence. The values of exhaust THC concentration vary from 1139 to 2779 PPM. CO and NOx vary from $0.15 \%$ to $0.5 \%$ and 0 to 1 PPM, respectively. Given the ultra low level of NOx emission in this engine, NOx prediction is not included in the grey-box modeling. 


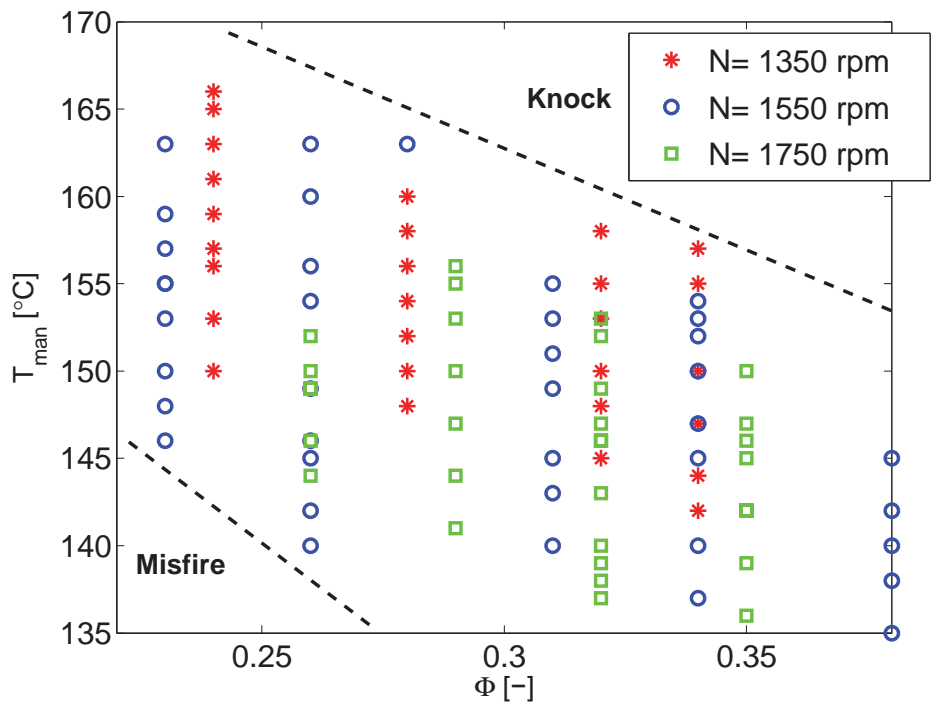

Figure 3.18: Operating range for the HCCI experimental data from Yanmar engine [1,2].

CA50-IMEP, $T_{e x h}$, and emissions (CO and THC) grey-box models are developed based on the Yanmar engine experimental data. The design approach of the ANN models are similar to those described in Section 3.4.1. Prediction performance of the grey-box models are then tested for the Yanmar engine. Results are shown in Figures 3.19, 3.20, 3.21, 3.22 and 3.23. Comparison results of the prediction performance for the clear-box, black-box, and grey-box models are also shown in Table 3.5. The validation results confirm that similarly to the Ricardo engine, the grey-box models outperform the other two peers. The RMSE is improved by about $4.2 \mathrm{CAD}, 0.9 \mathrm{bar}$, and $5^{\circ} \mathrm{C}$ for CA50, IMEP, and $T_{\text {exh }}$, respectively compared to the clear-box model and about $1 \mathrm{CAD}, 0.15 \mathrm{bar}$, and $5{ }^{\circ} \mathrm{C}$ compared to the black-box model. In addition, the grey-box model predicts the $\mathrm{CO}$ and THC concentrations with about 50\% and 39\% less error than the black-box model. 
Table 3.5

Comparison of average accuracy of the clear-box, black-box, and the grey-box models for Yanmar engine $[1,2]$.

\begin{tabular}{cccc}
\hline \hline Type of Model & Parameter & STD of Error & RMSE \\
\hline & CA50 [CAD] & 4.90 & 5.0 \\
& IMEP [bar] & 0.3 & 1.10 \\
Clear-box & $T_{\text {exh }}\left[{ }^{\circ} \mathrm{C}\right]$ & 13.7 & 11.1 \\
& CO [\%] & - & - \\
& THC [PPM] & - & - \\
& & & \\
& CA50 [CAD] & 1.40 & 1.70 \\
Black-box only & IMEP [bar] & 0.2 & 0.35 \\
& $T_{\text {exh }}\left[{ }^{\circ} \mathrm{C}\right]$ & 11.0 & 11.0 \\
& CO [\%] & 0.06 & 0.1 \\
& THC [PPM] & 392 & 734 \\
& & & \\
Grey-box & CA50 [CAD] & 1.20 & 0.80 \\
& IMEP [bar] & 0.2 & 0.20 \\
& $T_{\text {exh }}\left[{ }^{\circ} \mathrm{C}\right]$ & 9.0 & 6.5 \\
& CO [\%] & 0.03 & 0.05 \\
& THC [PPM] & 261 & 450 \\
\hline
\end{tabular}


(a)

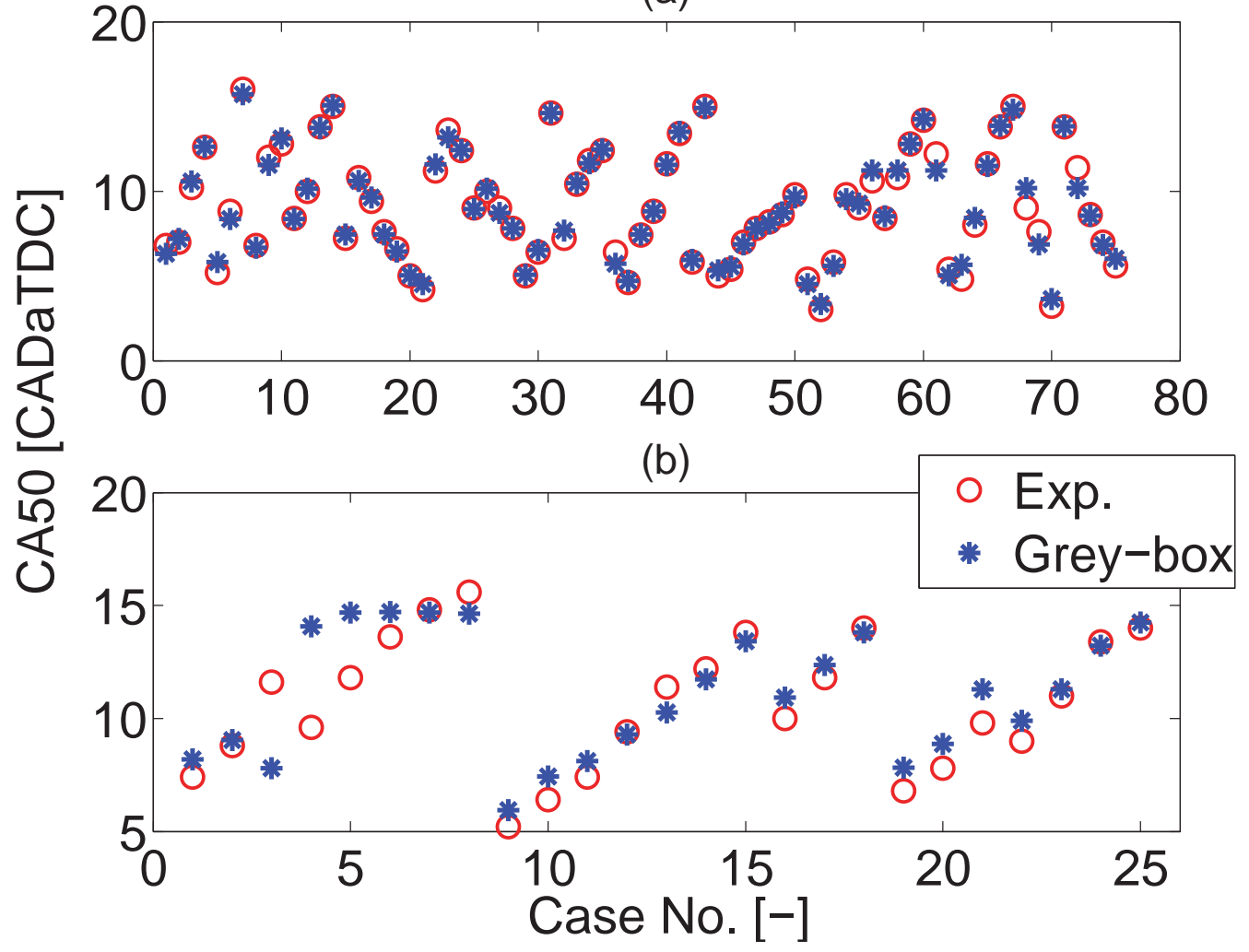

Figure 3.19: Prediction of CA50 for Yanmar engine: (a) Training, (b) Validation $[1,2]$. 


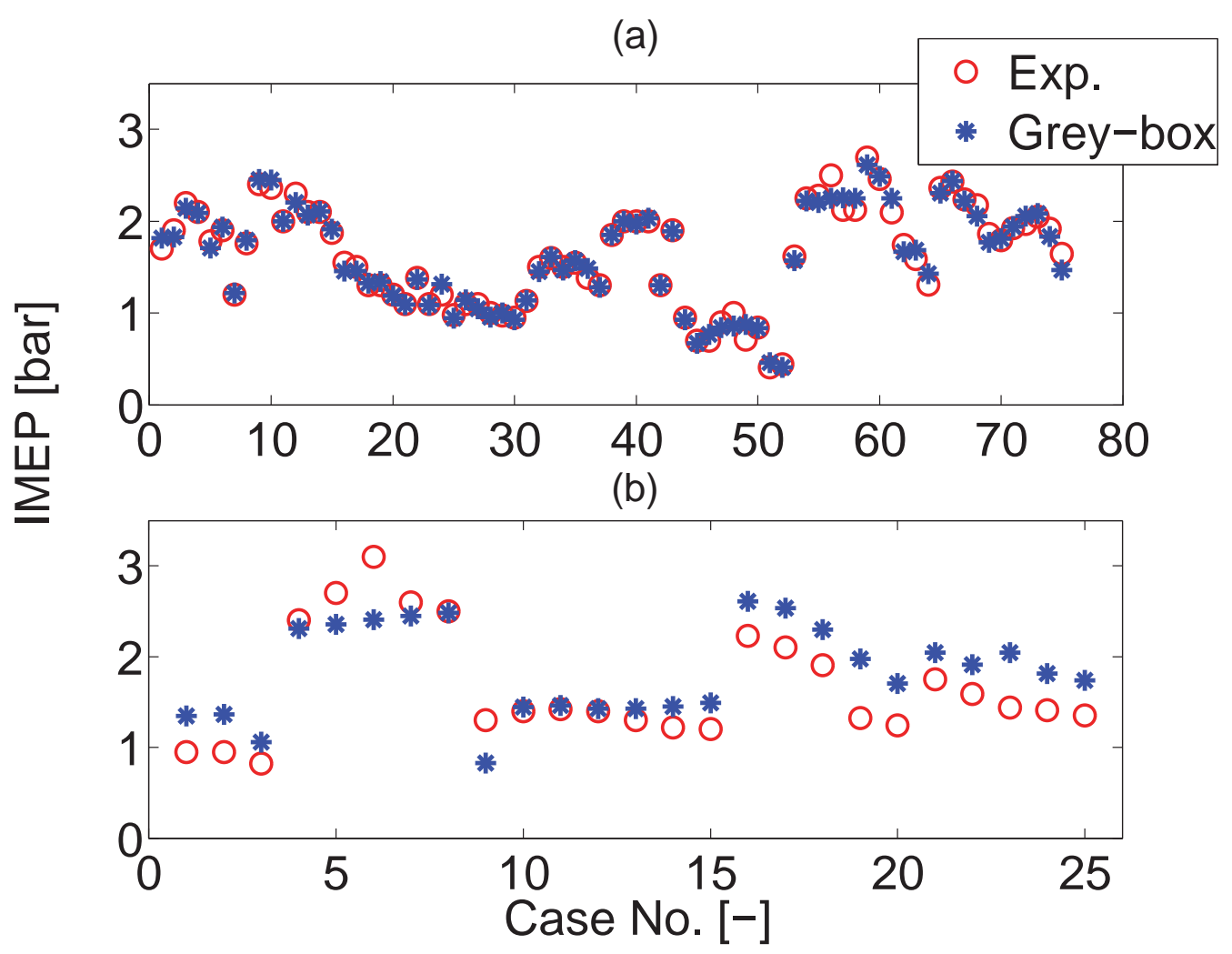

Figure 3.20: Prediction of IMEP for Yanmar engine: (a) Training, (b) Validation $[1,2]$. 


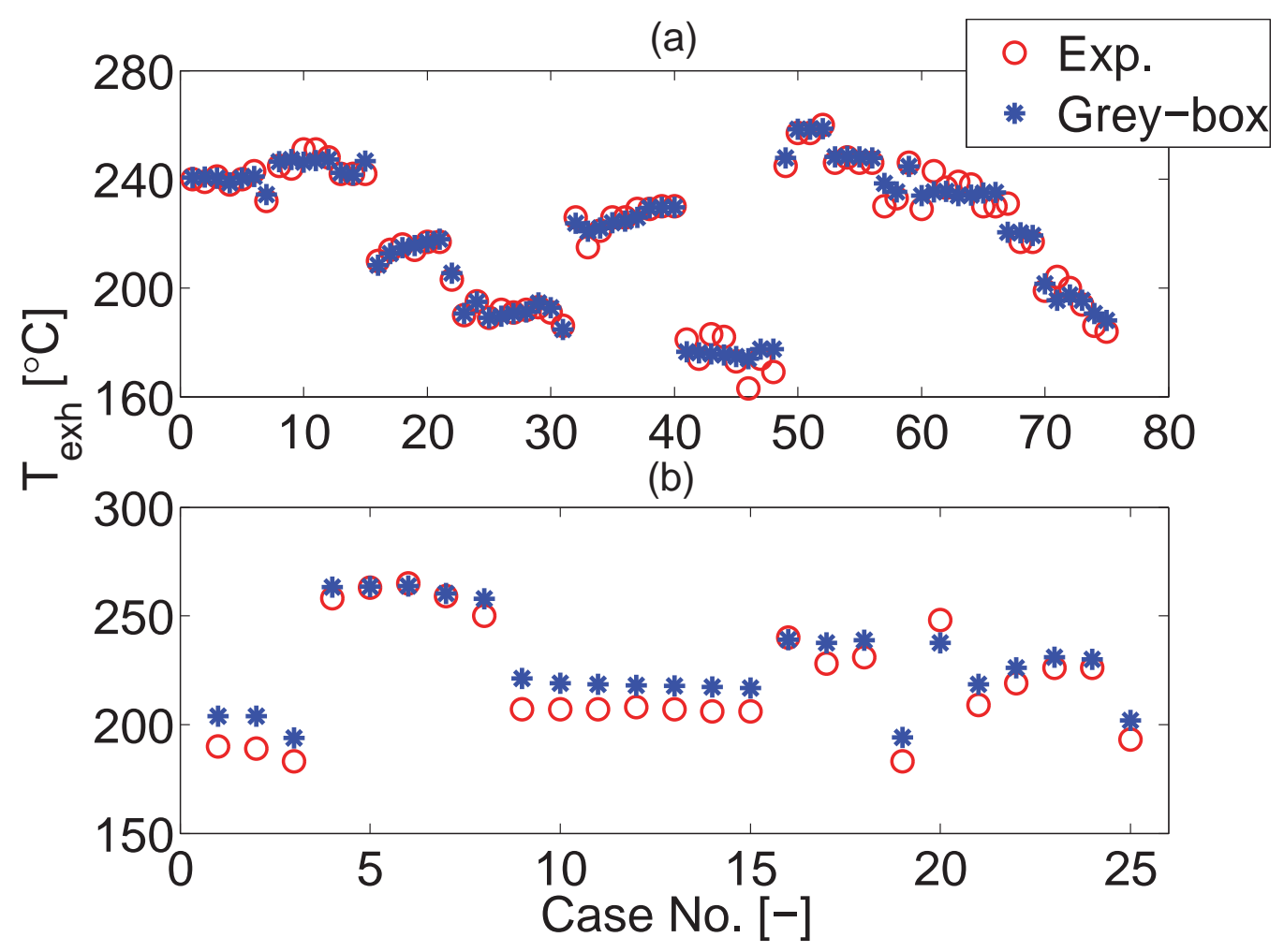

Figure 3.21: Prediction of $T_{\text {exh }}$ for Yanmar engine: (a) Training, (b) Validation $[1,2]$. 
(a)

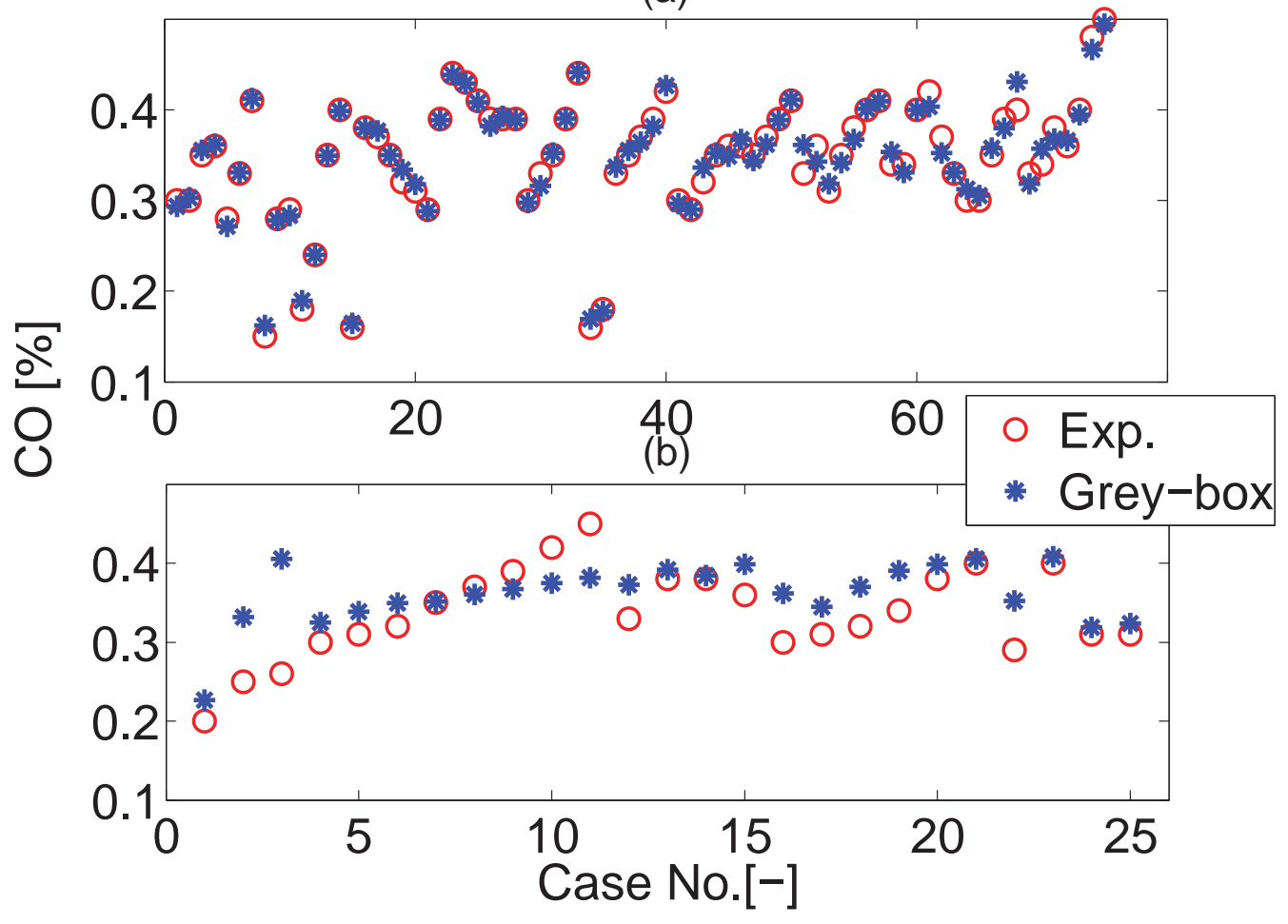

Figure 3.22: Prediction of $\mathrm{CO}$ for Yanmar engine: (a) Training, (b) Validation $[1,2]$. 
(a)

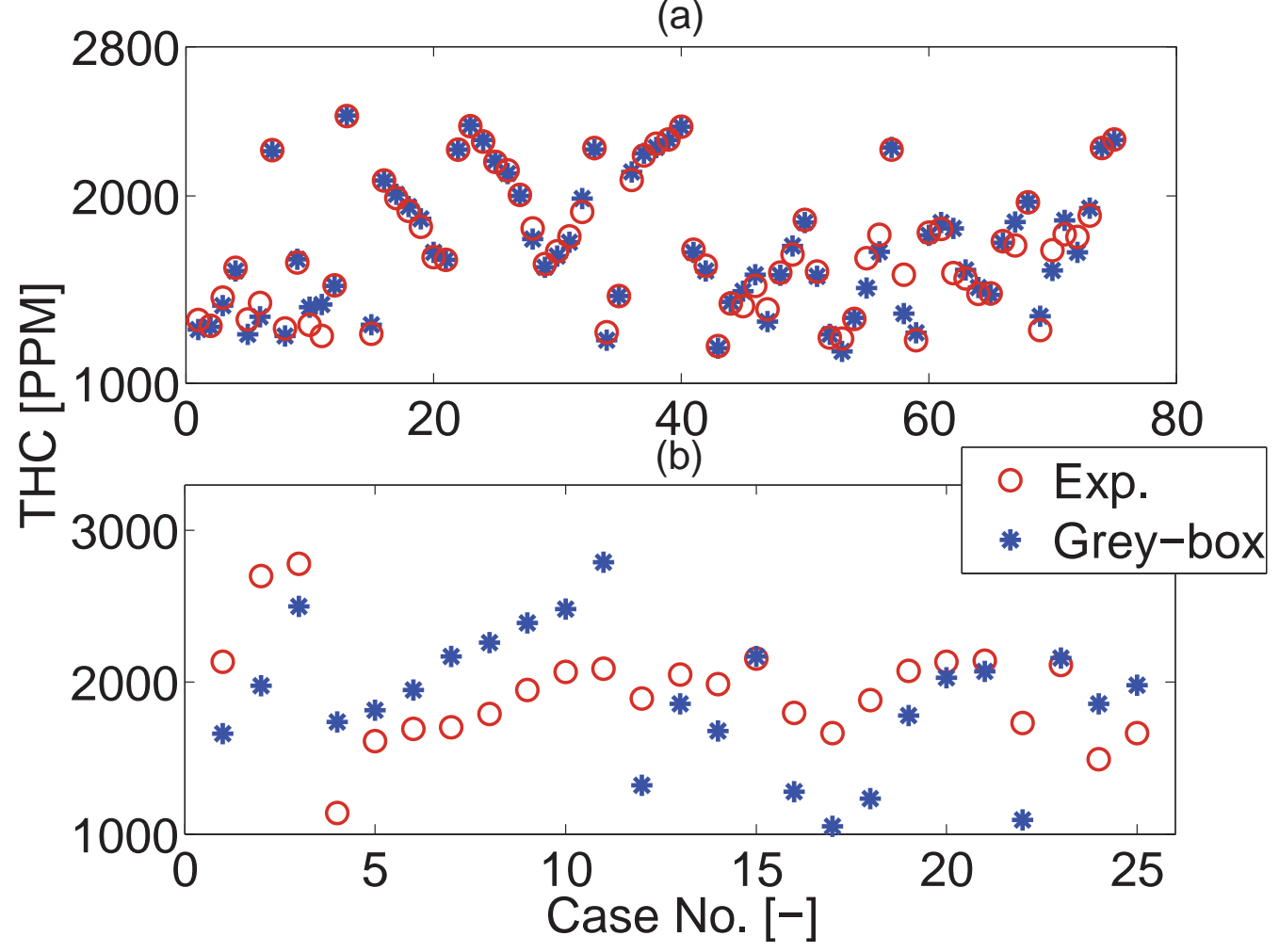

Figure 3.23: Prediction of THC concentration for Yanmar engine: (a) Training, (b) Validation [1,2]. 


\subsection{Summary}

This chapter consists of the results and findings of using a grey-box model for predicting engine performance parameters and emissions in HCCI operation. This is the first study of grey-box MIMO model for predicting HCCI engine outputs including CA50, IMEP, $T_{\text {exh }}$, and concentrations of CO, THC, and NOx engine-out emissions. Experimental data at 309 steady state and transient conditions from two different engines i.e. Ricardo and Yanmar engines are used for this study.

The average error for validation while using grey-box for predicting three main engine out emissions i.e. NOx, CO, and $\mathrm{THC}$ is $4 \mathrm{ppm}, 0.03 \%$ and $395 \mathrm{PPM}$ respectively for the Ricardo engine. The use of grey-box model for predicting the engine-out emissions like NOx, $\mathrm{CO}$, and $\mathrm{THC}$ results in the three times better prediction when compared to the black-box model. For Yanmar engine the use of grey-box model results in the predicting the emissions $\mathrm{CO}$ and THC emissions with average accuracy of $45 \%$ better than the black-box model.

The grey-box model from this chapter can be utilized in the design of HCCI controllers by:

$\dagger$ serving as an accurate simulation test bed to evaluate emission and engine performance, 
$\dagger$ design of ANN-based combustion comtrollers,

$\dagger$ finding optimum engine operating regions. 


\section{Chapter 4}

\section{Conclusion \& Future Work}

An experimental setup of an HCCI engine is completed in this thesis. This thesis also covers grey box modelling technique which can be used to address the needs of having an accurate control model for the real time control of HCCI engines. The following section summarizes the contributions from this thesis and also recommendations for future work which can be carried out in this area. 


\subsection{Conclusion}

\subsubsection{Experimental setup of an HCCI engine}

$\dagger$ The GM engine used in this study was a stock engine out of a BUICK REGAL 2011. This 2.0L turbocharged engine was modified heavily to work in HCCI mode. Most of the modification were required for data acquisition and mounting the engine for dyno testing.

$\dagger$ EGR modifications were performed, since the stock engine did not have EGR loop in the stock configuration. EGR loop consists of Ford EGR cooler and EGR valve. This loop can be converted either into pre or post turbo depending on the experimental requirements.

$\dagger$ Intake air circuit was modified to accommodate required changes and water cooled intercooler for turbocharged air and also adding airheater. The circuit was designed to be flexible enough to incorporate changes in the air circuit if required in future specially with the use of supercharger.

$\dagger$ Interface panels were designed and mounted on either sides of the cart. One is used for water connections for the intercooler and EGR cooler and the other is used for all the electrical connections required for the sensors, transducers, ECU, power and 
common ground.

$\dagger$ A number of sensors and several actuators were mounted on the engine after careful study and discussion in order to obtain the data required for HCCI study. The design has room to accommodate changes as per future requirements.

$\dagger$ Installation of incylinder pressure sensors were designed and finally mounted after machined by local manufacturing company.

\subsubsection{Grey box modelling of an HCCI engine}

This thesis developed the first MIMO grey-box model for predicting all the main HCCI engine outputs including CA50, IMEP, $T_{e x h}$, and concentrations of CO, THC, and NOx engine-out emissions. The grey-box models were designed to require minimum efforts for training while providing appropriate accuracy. The grey-box models were validated with extensive experimental data at 309 steady state and transient conditions for two different HCCI engine applications. Here is the summary of the main findings from this study:

$\dagger$ Ricardo HCCI engine with PRF fuels: The validation results showed that the emission grey-box model is able to predicted CA50, IMEP, $T_{e x h}, \mathrm{CO}$, THC, and NOx with the average errors of $0.8 \mathrm{CAD}, 0.2$ bar, $5.3{ }^{\circ} \mathrm{C}, 4 \mathrm{PPM}, 0.03 \%$, and $394 \mathrm{PPM}$, respectively. The grey-box models predicts CA50, IMEP, and $T_{e x h}$ with more than $80 \%, 84 \%$, and $74 \%$ better accuracy compared to those from the clear-box (physical) 
model and $72 \%, 60 \%$, and $60 \%$ improvement in prediction accuracy compared to those from the black-box model. In addition, the emissions grey-box model predicted $\mathrm{CO}$, THC, and NOx concentrations with three times better accuracy compared to those from the black-box model.

† Yanmar HCCI engine with ethanol fuel: The grey-box model is capable of predicting the main HCCI engine outputs with average $69 \%$ and $45 \%$ better accuracy than the clear-box and black-box models, respectively (for CA50, IMEP, and $T_{e x h}$ ) and about $45 \%$ average better accuracy than the black-box model for $\mathrm{HC}$ and $\mathrm{CO}$ concentrations.

\subsection{Future Work}

As this was the first study to develop an experimental setup of an HCCI at Michigan Technological University, there is vast scope of improvement and modifications which can be planned for the future HCCI studies. There are various tasks that can be performed on the existing setup to enhance the performance of the HCCI engine. The existing setup is designed in a way to adapt and incorporate the changes required for studying various HCCI trends and behaviour. The following section gives a summary of all the tasks in progress which are bound to be included in the existing setup

$\dagger$ Design and implementation of the Hybrid powertrain configuration along with the 
HCCI engine. This is planned to be done using the LG Chemical battery packs and the Remy electric motor. The coupling of this e-motor with the HCCI engine addresses the varying load question. This also provides a very unique setup for studying various aspects like the battery performance, e-motor performance and HCCI engine performance when coupled with hybrid powertrain configuration. The good part of this study will be the development and implementation of a control strategies for controlling the HCCI engine and e-motor in sync with each other.

$\dagger$ Supercharging station can be developed in order to induct the boosted air in the intake circuit while using a pre-turbo EGR loop. This station can be designed in order to function as a stand alone plug and play system. An electric motor can be used to power the supercharger. This station can also be used for the study of other naturally aspirated engine projects. Boosted air is one of the solutions for addressing the limited power out of the HCCI engines [22,30-32].

$†$ Develop and implement the control system for EGR loop and intake air heater. This is important part as it affects the temperature and composition of the combustion mixture, which directly coupled with the control of combustion timing of HCCI engines [21, 24, 88-90].

$\dagger$ Development and implementation a control strategy by using the dSPACE controller to control the HCCI engine operation.

$\dagger$ Design and manufacturing of port fuel injection system for the engine. This system 
can be used to study the performance of the current HCCI engine under port fuel injection conditions as the current engine consists of direct injection system. A duel spray system can also be used to study the effect of different fuel composition on the performance of the current HCCI engine. Fuel octane number is another factor affecting the HCCI ignition timing [10,16,91-93] and future dual PFI system can be used to adjust octane number of the input fuel for HCCI engine controls.

$\dagger$ Increase the compression ratio of the existing engine. This modification is required to enhance the auto ignition process of the HCCI engine setup [20,21,94]. One of major aspects affecting the HCCI operation is compression ratio $[95,96]$ as IVC temperature and pressure directly affect HCCI combustion [22, 23]. The cyclic variation in HCCI operation is observed to be lower while using high compression ratio [97]. In addition higher compression ratio will enable $\mathrm{HCCI}$ for broader engine operation [97]. 


\section{References}

[1] M. Bidarvatan, V. Thakkar and M. Shahbakhti. Grey-Box Modeling and Control of HCCI Engine Emissions. Procedings of 2014 American Control Conference, Portland, Oregon, USA, June 4-6 2014.

[2] M. Bidarvatan, V. Thakkar, M. Shahbakhti, B. Bahri and A. Abdul Aziz. Grey-Box Modeling of HCCI Engines. Applied Thermal Engineering, 70, 397-409, 2014.

[3] H. Zhao. Homogeneous Charge Compression Ignition (HCCI) and Controlled Auto Ignition (CAI) Engines for the Automotive Industry. Woodhead Publishing Ltd., Brunel University UK, 2007.

[4] O. Erlandsson. Early Swedish Hot-Bulb Engines - Efficiency and Performance Compared to Contemporary Gasoline and Diesel Engines. SAE Paper No. 2002-01-0115, 2002.

[5] L. A. Gussak. High Chemical Activity of Incomplete Combustion Products and a Method of Prechamber Torch Ignition for Avalanche Activation of Combustion in 
Internal Combustion Engines. SAE Paper No. 750890, 1975.

[6] S. Onishi, S. H. Jo, K. Shoda, P. D. Jo, and S. Kato. Active Thermo-Atmosphere Combustion (ATAC) A New Combustion Process for Internal Combustion Engines. SAE Paper No. 790501, 1979.

[7] M. Noguchi, Y. Tanaka, T. Tanaka, and Y. Takeuchi. A Study on Gasoline Engine Combustion by Observation of Intermediate Reactive Products during Combustion. SAE Paper No. 790840, 1979.

[8] P.M. Najt and D.E. Foster. Compression-Ignited Homogeneous Charge Combustion. SAE Paper No. 830264, 1983.

[9] R. H. Thring. Homogeneous Charge Compression Ignition (HCCI) Engines. SAE Paper No. 892068, 1989.

[10] T. Aoyama, Y. Hattori, J. Mizuta, and Y. Sato. An Experimental Study on Premixed-Charge Compression Ignition Gasoline Engine. SAE Paper No. 1996-01-960081, 1996.

[11] T.W. Ryan and T.J. Callahan. Homogeneous Charge Compression Ignition of Diesel Fuel. SAE Paper No. 961160, 1996.

[12] M. Christensen, A. Hultqvist, and B. Johansson. Demonstarting the Multi Fuel Capability of a Homogenous Charge Compression Ignition Engine with Variable Compression Ratio. SAE Paper No. 1999-01-3679, 1999. 
[13] European Federation for Transport and Environment. Waiting for Euro 5 and Euro 6 New Emission Standards for Passenger Cars, Vans and Lorries. http://www.t-e.nu/, 2004.

[14] US Environmental Protection Agency. 2007 Emission Standard for Heavy Duty Truck and Bus Engines. http://www.epa.gov/, 2000.

[15] S. B. Fiveland, R. Agama, M. Christensen, B. Johansson, J. Hiltner, F. Mauss, and D. N. Assanis. Experimental and Simulated Results Detailing the Sensitivity of Natural Gas HCCI Engines to Fuel Composition. SAE Paper No. 2001-01-3609, 2001.

[16] J. Olsson, P. Tunestål, and B. Johansson. Closed-Loop Control of an HCCI Engine. SAE Paper No.2001-01-1031, 2001.

[17] V. Manente, P. Tunestål, and B. Johansson. Mini High-Speed HCCI Engine Fueled with Ether: Load Range, Emission Characteristics and Optical Analysis. SAE Paper No. 2007-01-3606, 2007.

[18] U.S. Department of Energy. Homogeneous Charge Compression Ignition Technology - A Report to the U.S. Congress. Technical report, April 2001.

[19] R. H. Stanglmaier and C. E. Roberts. Homogeneous Charge Compression Ignition (HCCI): Benefits, Compromises, and Future Engine Applications. SAE Paper No. 1999-01-3682, 1999. 
[20] D. Law, D. Kemp, J. Allen, G. Kirkpatrick, and T. Copland. Controlled Combustion in an IC-Engine with a Fully Variable Valve Train. SAE Paper No. 2000-01-0251, 2000.

[21] M. Jennische. Closed-Loop Control of Start of Combustion in a Homogeneous Charge Compression Ignition Engine. M.Sc. Thesis, Lund Institute of Technology, 2003.

[22] J. Hyvönen, G. Haraldsson, and B. Johansson. Supercharging HCCI to Extend the Operating Range in a Multi-Cylinder VCR HCCI Engine. SAE Paper No. 2003-01-3214, 2003.

[23] G. Haraldsson, P. Tunestål, B. Johansson, and J. Hyvönen. HCCI Combustion Phasing with Closed-Loop Combustion Control Using Variable Compression Ratio in a Multi-Cylinder Engine. SAE Paper No. 2003-01-1830, 2003.

[24] R. Chen, N. Milovanovic, J. Turner, and D. Blundell. The Thermal Effect of Internal Exhaust Gas Recirculation on Controlled Auto-Ignition. SAE Paper No. 2003-01-0751, 2003.

[25] Yoshinaka Takeda, Nakagome Keiichi, and Niimura Keiichi. Emission Characteristics of Premixed Lean Diesel Combustion with Extremely Early Staged Fuel Injection. SAE Paper No. 961163, 1996.

[26] D. I. Handford and M. D. Checkel. Extending the Load Range of a Natural Gas HCCI Engine using Direct Injected Pilot Charge and External EGR. SAE Paper No. 2009-01-1884, 2009. 
[27] K. Nakagome, N. Shimazaki, K. Niimura, and S. Kobayashi. Combustion and Emission Characteristics of Premixed Lean Diesel Combustion Engine. SAE Paper No. 970898, 1997.

[28] C. S. Daw, K. D. Edwards, R. M. Wagner, and J. B. Green. Modeling Cyclic Variability in Spark-Assisted HCCI. Journal of Engineering for Gas Turbines and Power, 130, 2008.

[29] G. T. Kalghatgi and R. A. Head. Combustion Limits and Efficiency in a Homogeneous Charge Compression Ignition Engine. International Journal of Engine Research, 7, pages 215-236, 2006.

[30] M. Christensen, B. Johansson, P. Amneus, and F. Mauss. Supercharged Homogeneous Charge Compression Ignition. SAE Paper No. 980787, 1998.

[31] Y. Iwabuchi, K. Kawai, T. Shoji, and Y. Takeda. Trial of New Concept Diesel Combustion System Premixed Compression-Ignition Combustion. SAE Paper No. 1999-01-0185, 1999.

[32] R. Sun, R. Thomas, and C.L. Gray. An HCCI Engine: Power Plant for a Hybrid Vehicle. SAE Paper No. 2004-01-0933, 2004.

[33] J.O. Olsson, P. Tunestål, and B. Johansson. Boosting for High Load HCCI. SAE Paper No. 2004-01-0940, 2004. 
[34] J.O. Olsson, P. Tunestal, G. Haraldsson, and B. Johansson. A Turbo Charged Dual Fuel HCCI Engine. SAE Paper No. 2001-01-1896, 2001.

[35] J. Martinez-Frias, S.M. Aceves, D. Flowers, J.R. Smith, and R. Dibble. Equivalence Ratio-EGR Control of HCCI Engine Operation and the Potential for Transition to Spark-ignited Operation. SAE Paper No. 2001-01-3613, 2001.

[36] L. Koopmans, H. Strom, S. Lundgren, O. Backlund, and I. Denbratt. Demonstrating a SI-HCCI-SI Mode Change on a Volvo 5-Cylinder Electronic Valve Control Engine. SAE Paper No. 2003-01-0753, 2003.

[37] H. Santoso, J. Matthews, and W. K. Cheng. Managing SI/HCCI Dual-Mode Engine Operation. SAE Paper No. 2005-01-0162, 2005.

[38] Y. Guezennec, C. Musardo, B. Staccia, S. Midlam-Mohler, E. Calo, P. Pisu, and G. Rizzoni. Supervisory Control for NOx Reduction of an HEV With a Mixed-Mode HCCI/DI Engine. SAE Paper No. 2004-05-0123, 2004.

[39] S. Midlam-Mohler, S. Haas, Y. Guezennec, M. Bargende, and G. Rizzoni. Mixed-Mode Diesel HCCI/DI With External Mixture Preparation. SAE Paper No. 2004-05-0446, 2004.

[40] GP50. http://www.gp50.com/pdf/11.pdf.

[41] Accucoder. http://www.encoder.com/literature/datasheet-260.pdf.

[42] Bosch. http://industrial.boschautoparts.com. 
[43] S. Saxena, N. Shah, I. Bedoya, and A. Phadke. Understanding Optimal Engine Operating Strategies for Gasoline-Fueled HCCI Engines Using Crank-Angle Resolved Exergy Analysis. Applied Energy, 114, pages 155-163, 2014.

[44] F. Zhao, F. Asmus, D.N. Assanis, J.E. Dec, J.A. Eng, and P.M. Najt. Homogeneous Charge Compression Ignition (HCCI) engines. SAE paper PT-94, 2003.

[45] M. Shahbakhti, R. Lupul, and C.R. Koch. Sensitivity analysis and modeling of HCCI auto-ignition timing. In Proceeding of the Fifth IFAC Symposium on Advances in Automotive Control, pages 303-310, 2007.

[46] S. Williams, L. Hu, T. Nakazono, H. Ohtsubo, and M. Uchida. Oxidation Catalysts for Natural Gas Engine Operating Under HCCI or SI Conditions. SAE International Journal of Fuels and Lubricants, 1, pages 326-337, 2009.

[47] P. Strandh, J. Bengtsson, R. Johansson, P. Tunestål, and B. Johansson. Variable Valve Actuation for Timing Control of a HCCI Engine. SAE Paper 2005-01-0147, 2005.

[48] G. Haraldsson, P. Tunestål, and B. Johansson. Transient Control of a Multi Cylinder HCCI Engine During a Drive Cycle. SAE Paper 2005-01-0153, 2005.

[49] A. Audet and C.R. Koch. Actuator Comparison for Closed Loop Control of HCCI Combustion Timing. SAE Paper 2009-01-1135, 2009. 
[50] J. Bengtsson, P. Strandh, R. Johansson, P. Tunestål, , and B. Johansson. Hybrid Modeling of Homogeneous Charge Compression Ignition (HCCI) Engine Dynamics - A Survey. International Journal of Control, 80(11):1814-1847, 2007.

[51] P. Erduranli M. Sahir Salman M. Gölcü, Y. Sekmen. Artificial Neural-Network Based Modeling of Variable Valve-Timing in a Spark-Ignition Engine. Applied Energy, 81(2):187-197, 2005.

[52] A. Parlak, Y. Islamoglu, H. Yasar, and A. Egrisogut. Application of Artificial Neural Network to Predict Specific Fuel Consumption and Exhaust Temperature for a Diesel Engine. Applied Thermal Engineering, 26(8):824-828, 2006.

[53] C. Sayin, H.M. Ertunc, M. Hosoz, I. Kilicaslan, and M. Canakci. Performance and Exhaust Emissions of a Gasoline Engine Using Artificial Neural Network. Applied Thermal Engineering, 27(1):46-54, 2007.

[54] N. Kara Togun and S. Baysec. Prediction of Torque and Specific Fuel Consumption of a Gasoline Engine by Using Artificial Neural Networks. Applied Energy, 87(1):349-355, 2010.

[55] J. Porteiro, J. Collazo, D. Patiño, and J.L. Míguez. Diesel Engine Condition Monitoring using a Multi-Net Neural Network System with Nonintrusive Sensors. Applied Thermal Engineering, 31(17):4097-4105, 2011. 
[56] A. Çay, Y.and Çiçek, F. Kara, and S. Sağiroğlu. Prediction of Engine Performance for an Alternative Fuel using Artificial Neural Network. Applied Thermal Engineering, 37, pages 217-225, 2012.

[57] B. Liu, C. Zhao, F. Zhang, T. Cui, and J. Su. Misfire Detection of a Turbocharged Diesel Engine by using Artificial Neural Networks. Applied Thermal Engineering, 55, pages 26-32, 2013.

[58] Y. Choi and J-Y. Chen. Fast Prediction of Start-of-Combustion in HCCI with Combined Artificial Neural Networks and Ignition Delay Model. Proceedings of the Combustion Institute, 30(2):2711-2718, 2005.

[59] M. Mirhassani, X. Chen, A. Tahmasebi, and M. Ahmadi. On Control of HCCI Combustion-Neural Network Approach. In Proceeding of the 2006 IEEE International Conference on Control Applications, pages 1669-1674, 2006.

[60] V.M. Janakiraman, X. Nguyen, and D. Assanis. Nonlinear Identification of a Gasoline HCCI Engine using Neural Networks Coupled with Principal Component Analysis. Applied Soft Computing, 13(5):2375-2389, 2013.

[61] B. Bahri, A.A. Aziz, M. Shahbakhti, and M.F. Muhamad Said. Understanding and Detecting Misfire in an HCCI Engine Fuelled with Ethanol. Applied Energy, 108, pages 24-33, 2013a. 
[62] B. Bahri, A.A. Aziz, M. Shahbakhti, and M.F. Muhamad Said. Analysis and Modeling of Exhaust Gas Temperature in an Ethanol Fuelled HCCI Engine. Journal of Mechanical Science and Technology, 27(11):3531-3539, $2013 \mathrm{~b}$.

[63] M. Bidarvatan, M. Shahbakhti, S.A. Jazayeri, and C.R. Koch. Cycle-to-cycle Modeling and Sliding Mode Control of Blended Fuel HCCI Engine. Control Engineering Practice, 24, pages 79-91, 2014.

[64] K. Ebrahimi, C.R. Koch, and A. Schramm. A Control Oriented Model with Variable Valve Timing for HCCI Combustion Timing Control. SAE Paper 2013-01-0588, 2013a.

[65] C-J. Chiang, A.G. Stefanopoulou, and M. Jankovic. Nonlinear Observer-Based Control of Load Transitions in Homogeneous Charge Compression Ignition Engines. IEEE Transactions on Control Systems Technology, 15(3): 438-448, 2007.

[66] C-J. Chiang, C-C. Huang, and M. Jankovic. Discrete-Time Cross-Term Forwarding Design of Robust Controllers for HCCI Engines. Procceding of the 2010 American Control Conference, pages 2218-2223, 2010.

[67] M. Bidarvatan, M. Shahbakhti, and S.A. Jazayeri. Model-Based Control of Combustion Phasing in an HCCI Engine. SAE International Journal of Engines, 5(3):1163-1176, 2012. 
[68] A. Widd, K. Ekholm, P. Tunestål, and R. Johansson. Physics-Based Model Predictive Control of HCCI Combustion Phasing Using Fast Thermal Management and VVA. IEEE Transactions on Control Systems Technology, 20(3):688-699, 2012.

[69] G.M. Shaver, J.C. Gerdes, and M. Roelle. Physics-Based Closed-Loop Control of Phasing, Peak Pressure and Work Output in HCCI Engines Utilizing Variable Valve Actuation. Proceeding of the 2004 American Control Conference, pages 150-155, 2004.

[70] G.M. Shaver, J.C. Gerdes, and M. Roelle. Physics-Based Modeling and Control of Residual-Affected HCCI Engines. ASME Journal of Dynamic Systems, Measurement, and Control, 131(2), 2009.

[71] N. Ravi, M.J. Roelle, H-H. Liao, A.F. Jungkunz, C-F. Chang, S. Park, and J.C. Gerdes. Model-Based Control of HCCI Engines Using Exhaust Recompression. IEEE Transactions on Control Systems Technology, 18(6)1289-1302, 2010.

[72] N. Ravi, H-H. Liao, A.F. Jungkunz, A. Widd, and J.C. Gerdes. Model Predictive Control of HCCI Using Variable Valve Actuation and Fuel Injection. Control Engineering Practice, 20(4):421-430, 2012a.

[73] N. Ravi, H-H. Liao, A.F. Jungkunz, C-F. Chang, H-H. Song, and J.C. Gerdes. Modeling and Control of an Exhaust Recompression HCCI Engine Using Split Injection. ASME Journal of Dynamic Systems, Measurement, and Control, 134(1), $2012 b$. 
[74] M. Bidarvatan and M. Shahbakhti. Two-input Two-Output Control of Blended Fuel HCCI Engines. SAE Paper 2013-01-1663, 2013a.

[75] V. Tandra and N. Srivastava. Optimal Peak Pressure and Exhaust Temperature Tracking Control for a Two-Zone HCCI Engine Model with Mean Burn Duration. SAE Paper 2009-01-1130, 2009.

[76] K. Ebrahimi and C.R. Koch. HCCI Combustion Timing Control with Variable Valve Timing. Proceeding of the 2013 American Control Conference, 4429-4434, 2013b.

[77] S. Zhang, G. Zhu, Y. Yoon, and Z. Sun. A Control Oriented Charge Mixing and HCCI Combustion Model for Internal Combustion Engines. ASME Journal of Dynamic Systems, Measurement, and Control, 2, pages 321-327, 2012.

[78] P. Kirchen, M. Shahbakhti, and C.R. Koch. A Skeletal Kinetic Mechanism for PRF Combustion in HCCI Engines. Combustion Science and Technology, 179(6):1059-1083, 2007.

[79] N.P. Komninos, D.T. Hountalas, and D.A. Kouremenos. Description of In-Cylinder Combustion Processes in HCCI Engines Using a Multi-Zone Model. SAE Paper No. 2005-01-0171, 2005.

[80] D.L. Flowers, S.M. Aceves, J. Martinez-Frias, and R.W. Dibble. Prediction of Carbon Monoxide and Hydrocarbon Emissions in Iso-Octane HCCI Engine Combustion Using Multizone Simulations. Proceedings of the Combustion Institute, 29(1):687-694, 2002. 
[81] M. Bidarvatan and M. Shahbakhti. Grey-Box Modeling for HCCI Engine Control. volume Proceedings of the 2013 ASME Internal Combustion Engine Division Fall Technical Conference, ASME Paper No. ICEF2013-19097, 2013b.

[82] M. Shahbakhti, A. Ghazimirsaied, and C.R. Koch. Experimental Study of Exhaust Temperature Variation in a Homogeneous Charge Compression Ignition Engine. Proceedings of the Institution of Mechanical Engineers, Part D: Journal of Automobile Engineering, 224(9):1177-1197, 2010.

[83] J.B. Heywood. Internal Combustion Engine Fundamentals. McGraw-Hill New York, 1998.

[84] V. Ferrari, H. Rabinowitz, S. Siemund, T. Collinq, and B. Campbell. Achieving EURO III and EURO IV with Ultra-Low Precious Metal Loadings. SAE Paper 2007-01-2565, 2007.

[85] M. Shahbakhti and C.R. Koch. Physics Based Control Oriented Model for HCCI Combustion Timing. AMSE Journal of Dynamic Systems, Measurement, and Control, 132(2), 2010.

[86] M. Dehghani Firoozabadi, M. Shahbakhti, C.R. Koch, and S.A. Jazayeri. Thermodynamic Control-Oriented Modeling of Cycle-to-Cycle Exhaust Gas Temperature in an HCCI Engine. Applied Energy, 110, pages 236-243, 2013.

[87] S. Haykin. Neural Networks and Learning Machines. Prentice Hall New York, 2009. 
[88] P. Caton, A. Simon, J. C. Gerdes, and C. Edwards. Residual effected Homogeneous Charge Compression Ignition at Low Compression Ratio Using Exhaust Reinduction. International Journal of Engine Research, (4), 163-177, 2003.

[89] S. Yamaoka, H. Kakuya, S. Nakagawa, T. Okada, A. Shimada, and Y. Kihara. HCCI Operation Control in a Multi-Cylinder Gasoline Engine. SAE Paper No. 2005-01-0120, 2005.

[90] F. Agrell, H.E. Ångström, B. Eriksson, J. Wikander, and J. Linderyd. Integrated Simulation and Engine Test of Closed-Loop HCCI Control by Aid of Variable Valve Timings. SAE Paper No. 2003-01-0748, 2003.

[91] Magnus Christensen, Bengt Johansson, and Patrick Einewall. Homogeneous Charge Compression Ignition (HCCI) Using Isooctane, Ethanol and Natural Gas A Comparison with Spark-Ignition Operation. SAE Paper No. 972874, 1997.

[92] B. Johansson. Homogeneous Charge Compression Ignition: The Future of IC Engines? International Journal of Vehicle Design, 44, pages 1-19, 2007.

[93] J. Kamio, T. Kurotani, T. Sato, Y. Kiyohiro, K. Hashimoto, and T. Gunji. A Study on Combustion Control by Dual-Fuel Strategies. SAE Paper No. 2007-08-0242, 2007.

[94] J. Bengtsson, P. Strandh, R. Johansson, P. Tunesta, and B. Johansson. Hybrid Modelling of Homogeneous Charge Compression Ignition (HCCI) Engine Dynamics - A Survey. International Journal of Control, 80, pages 1814-1847, 2007. 
[95] Z. Serinyel, L. Le Moyne, and P. Guibert. Homogeneous Charge Compression Ignition as an Alternative Combustion Mode for the Future of Internal Combustion Engines. International Journal of Vehicle Design, 44(1-2):20-40, 2007.

[96] M. Shahbakhti and C. R. Koch. Characterizing the Cyclic Variability of Ignition Timing in an HCCI Engine Fueled with n-Heptane/iso-Octane Blend Fuels. International Journal of Engine Research, 9(5):361-397, 2008.

[97] C. Liu, G. A. Karim, A. Sohrabi, and F. Xiao. Combustion and Cyclic Variation for Lean Mixture Operation. ASME Internal Combustion Engine Spring Technical Conference, ICES2006-1392, 2006. 


\section{Appendix A}

\section{Physical HCCI Engine Model $[74,85,86]$}

INTAKE STROKE

$$
\begin{aligned}
P_{i v c} & =\left[\frac{N^{\bar{a}_{1}} \phi^{\bar{a}_{2}}}{T_{m a n}^{\bar{a}_{3}}}\right] P_{m a n} \\
T_{i v c} & =\left(\bar{b}_{1} T_{m a n}^{2}+b_{2} T_{m a n}+\bar{b}_{3}\right) \frac{\phi^{\bar{c}_{1}} N^{\bar{c}_{2}}}{(1+E G R)^{\bar{c}_{3}}}
\end{aligned}
$$

\section{COMPRESSION STROKE}

$$
T_{s o c}=T_{m i x}\left(\frac{V_{i v c}}{V_{s o c}}\right)^{k_{c-1}}
$$




$$
P_{s o c}=P_{i v c}\left(\frac{V_{i v c}}{V_{s o c}}\right)^{k_{c}}
$$

\section{COMBUSTION STROKE}

$$
\begin{aligned}
& \int_{\theta_{i v c}}^{\theta_{s o c}} \frac{\phi^{b}}{\operatorname{Eexp}\left(\frac{c\left(P_{i v c} V_{c}^{k_{c}}\right)^{D}}{T_{i v c} V_{c}^{k_{c}-1}}\right) N} d \theta=1 \\
& V_{c}=\frac{V_{i v c}}{V_{\theta}} E=e_{1} E G R+e_{2} \\
& x_{b}(\theta)=1-\exp \left(-A\left[\frac{\theta-\theta_{s o c}}{\theta_{d u r}}\right]^{B}\right) \\
& C A 50=\theta_{@ x_{b}=50 \%}
\end{aligned}
$$

$U_{e o c, k+1}=U_{s o c}+Q_{f}-Q_{w}-W_{s o c-e o c}$

$W_{s o c-e o c}=m_{f} L H V P_{m a n}^{A} \frac{N^{B}}{(1+E G R)^{C}}\left(D_{1} \theta_{s o c}^{2}+D_{2} \theta_{s o c}+D_{3}\right)$ 


$$
Q_{f}=m_{f} \operatorname{CoCLHV}_{f}
$$

$$
\begin{aligned}
C o C & =\phi^{A} \frac{\left(P_{\text {man }}^{B}\right)}{(1+E G R)^{C}}\left(D_{1} \theta_{s o c}^{2}+D_{2} \theta_{s o c}+D_{3}\right) \\
T_{e o c} & =\frac{\left(\sum_{i} C_{v, i} y_{i}\right)_{\text {Reactant }} T_{s o c}+\frac{m_{f}}{m_{\text {mix }}} L H V\left(C o C-W_{\text {soc }-e o c}\right)}{\left(\sum_{i} C_{v, i} y_{i}\right)_{\text {Products }}}
\end{aligned}
$$

$$
P_{e o c}=\frac{P_{i v c} \frac{V_{i v c}}{V_{e o c}} \frac{T_{e o c}}{T_{m i x}} R_{e o c}}{R_{i v c}}
$$

\section{EXHAUST STROKE}

$$
T_{2}=\frac{T_{1}\left(\sum_{i} m_{i} C_{v_{i}}-\sum_{i} C_{p_{i}}\left(m_{i, c e}+m_{i, e c}\right)+Q_{w}+P_{1} d V\right.}{\sum_{i} m_{i, 2} C_{v_{i}}}
$$




\section{EXHAUST GAS EXCHANGE FLOW}

$$
\begin{aligned}
& \text { if } \frac{P_{T}}{P_{0}}>\left(\frac{2}{k+1}\right)^{k / k-1}, \\
& \dot{m}=\frac{C_{D} A_{R} P_{0}}{\sqrt{R T_{0}}}\left(\frac{P_{T}}{P_{0}}\right)^{1 / k}\left[\frac{2 k}{k-1}\left(1-\left(\frac{P_{T}}{P_{0}}\right)^{\frac{k-1}{k}}\right)\right]^{1 / 2}
\end{aligned}
$$

otherwise,

$$
\begin{aligned}
& \dot{m}=\frac{C_{D} A_{R} P_{0}}{\sqrt{R T_{0}}} k^{1 / 2}\left(\frac{2}{k+1}\right)^{\frac{k+1}{2(k-1)}} \\
& A_{R}=\pi d_{v} L_{v}
\end{aligned}
$$

\section{EXHAUST GAS TEMPERATURE}

$$
T_{e x h}=\frac{T_{e v o}+T_{e v c}}{2}\left[\frac{2 m_{t}\left(1-X_{r}\right) c_{p}-h_{c} A_{R}}{2 m_{t}\left(1-X_{r}\right) c_{p}+h_{c} A_{R}}\right]+\frac{2 h_{c} A_{R}}{2 m_{t}\left(1-X_{r}\right) c_{p}+h_{c} A_{R}} T_{w}
$$

IMEP

$$
I M E P=\frac{1}{V_{d i s}} \oint P d V=m_{m i x} \frac{C_{V, m i x}}{V_{d i s}}\left(T_{i v c}-T_{s o c}+T_{e o c}-T_{e v c}\right)
$$




\section{Appendix B}

\section{M.Sc. Publications}

\section{B.1 Peer Reviewed Papers}

1. M. Bidarvatan, V. Thakkar, M. Shahbakhti, "Grey-box Modeling and Control of HCCI Engine Emissions", Proceedings of the 2014 American Control Conference, Portland, Oregon, USA June 4-6, 2014. Permission for the use can be found at http://www.ieee.org/publications_standards/publications/rights/permissions_faq.pdf

2. M. Bidarvatan, V. Thakkar, M. Shahbakhti, B. Bahri, A. Abdul Aziz, "Grey-box Modeling of HCCI Engines", Journal of Applied Thermal Engineering, to appear in vol. 70, Issue 1, pages 397-409, Sept. 2014. Permission for use can be found at http://www.elsevier.com/journal-authors/author-rights-and-responsibilities 
A version including figures and text from the above technical presentation [1] and paper [2] is included as Chapter 3 in this thesis. Permission for the academic use of figures and published material can found on the publisher's website on the link provided with each item in Appendix B.1.

\section{B.2 Permission from Co-author}

Following is the permission from co-author of [1] and [2] for including the figures and results in this thesis as a part of Chapter 3.

\section{Hello Vishal,}

I hereby grant permission to you for using the contents from the published paper entitled: "Grey-Box Modeling and Control of HCCI Engine Emissions" presented at 2014 American Control Conference (ACC) in your M.S. thesis.

Best regards, Mehran

2. Hello Vishal,

I hereby grant permission to you for using the contents from the paper entitled: "Grey-Box Modeling of HCCI Engines" published in Journal of Applied Thermal Engineering in your M.S. thesis.

Best regards, Mehran Bidarvatan, M.Sc. Ph.D. Candidate and Graduate Student 
Research Assistant 910 R.L. Smith Building Mechanical Engineering-Engineering Mechanics Department Michigan Tech. University, Houghton, MI 49931-1295 Tel:(906)370-0640 Email: mbidarva@mtu.edu, mbidarvatan@gmail.com 
Appendix C

Data Sheets 


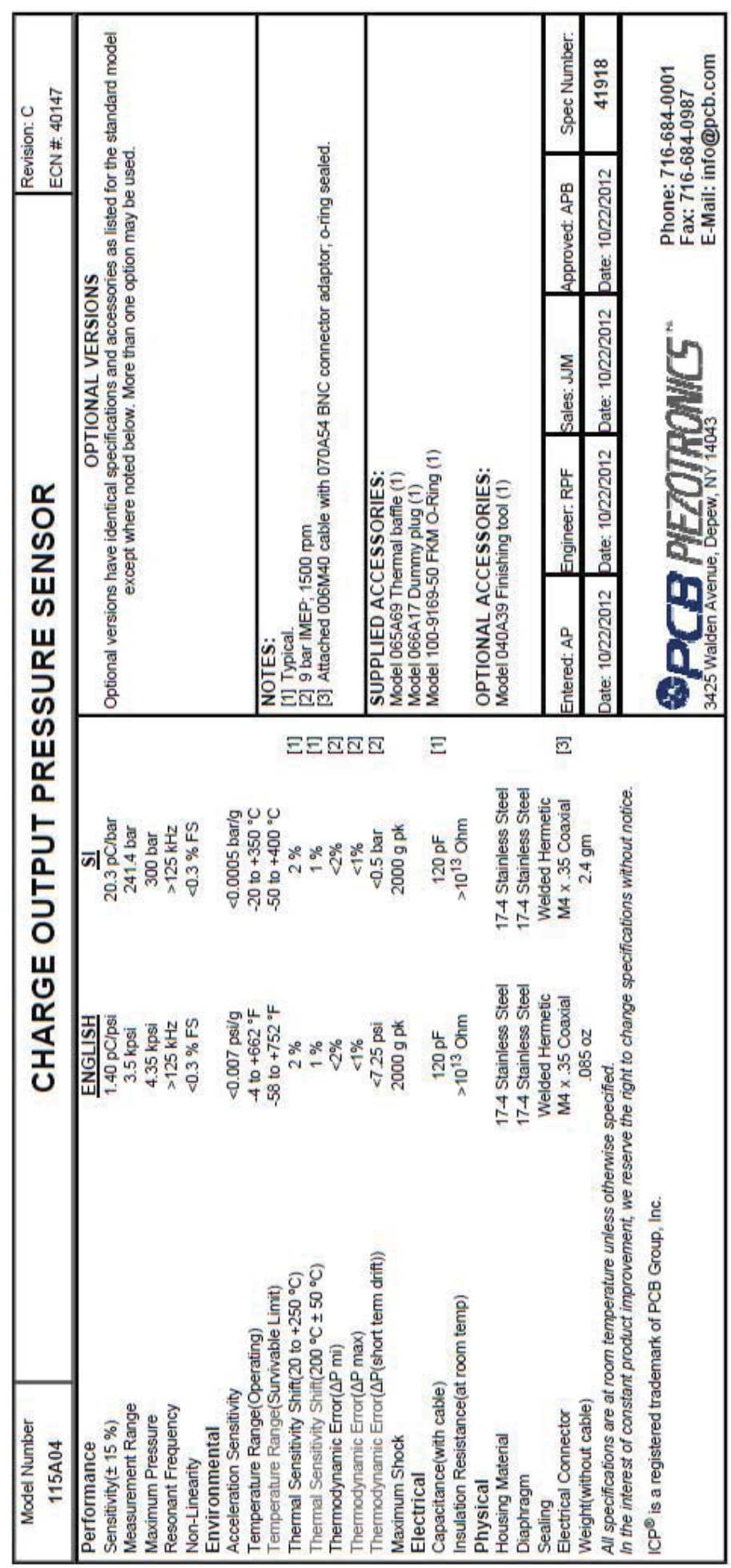

Figure C.1: Technical data sheet 1 of incylinder pressure transducer 


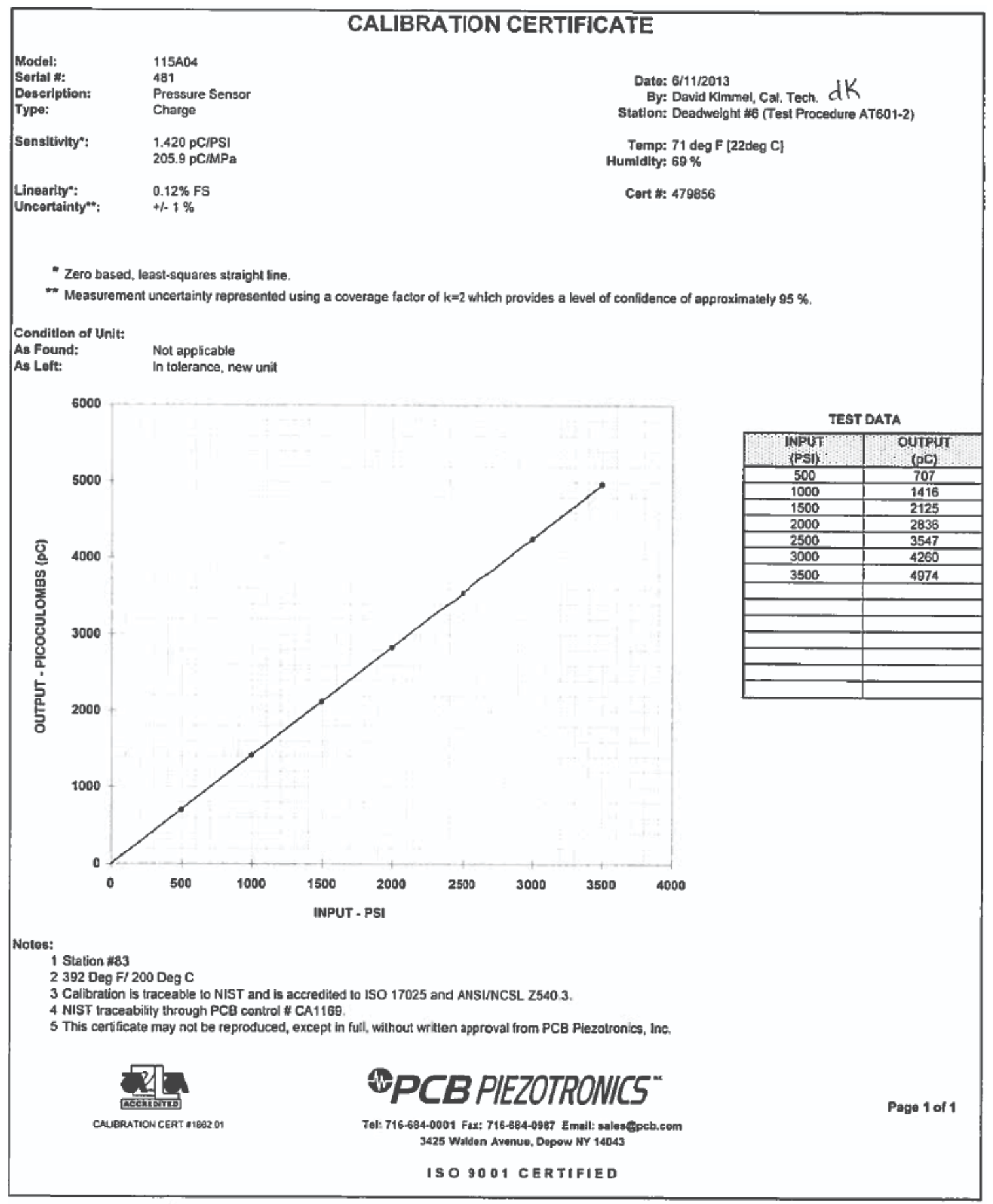

Figure C.2: Technical data sheet 2 of incylinder pressure transducer 
Model 260
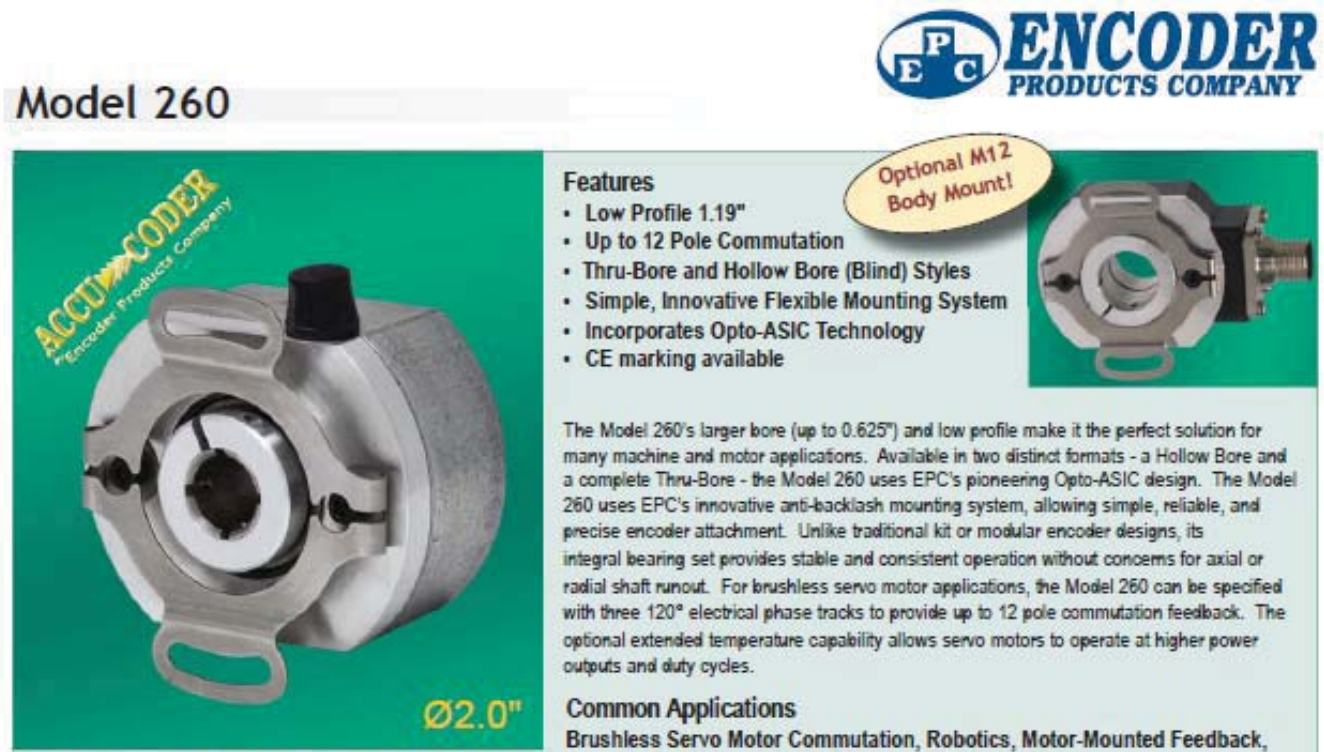

Features

- Low Profile $1.19^{n}$

- Up to 12 Pole Commutation

- Thru-Bore and Hollow Bore (Blind) Styles

- Simple, Innovative Flexible Mounting System

- Incorporates Opto-ASIC Technology

- CE marking available

The Model 260 's larger bore (up to $0.625^{\circ}$ ) and low profile make it the perfect solution for many machine and motor applicatons. Avalable in two distinct formats - a Hollow Bore and a complete Thru-Bore - the Nodel 260 uses EPC's pioneering Opto-ASIC design. The Node 260 uses EPC's innovative ant-backlash mounting system, allowing simple, reliable, and precise encoder attachment. Unilike traditional kit or modular encoder designs, its integral bearing set provides stable and consistent operation without concems for axial of radial shaft runout. For brushless senv motor applications, the Model 260 can be specifed with three $120^{\circ}$ electrical phase tracks to provide 40 to 12 pole commutation feedback. The optional extended temperature capobility allows sewo motors to operate at higher power outputs and duty cycles.

Common Applications

Brushless Servo Motor Commutation, Robotics, Motor-Mounted Feedback,

Model 260 Ordering Guide Assembly Machines, Digital Plotters, High Power Motors

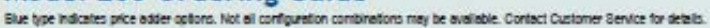

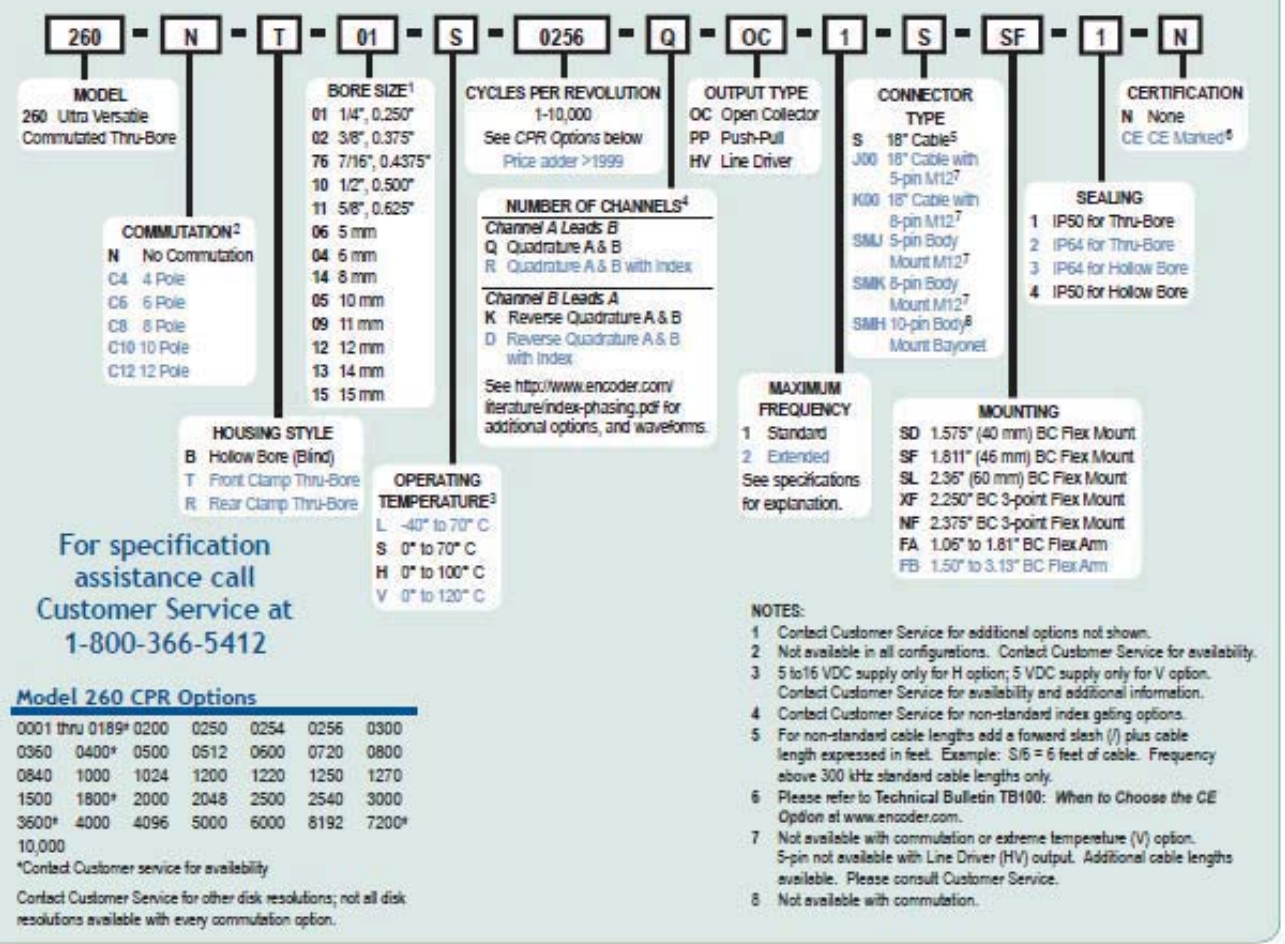

1-800-366-5412 - www.encoder.com · sales@encoder.com

Rev. 04/08/14

Figure C.3: Technical data sheet 1 of shaft encoder. 


\section{Model 260}

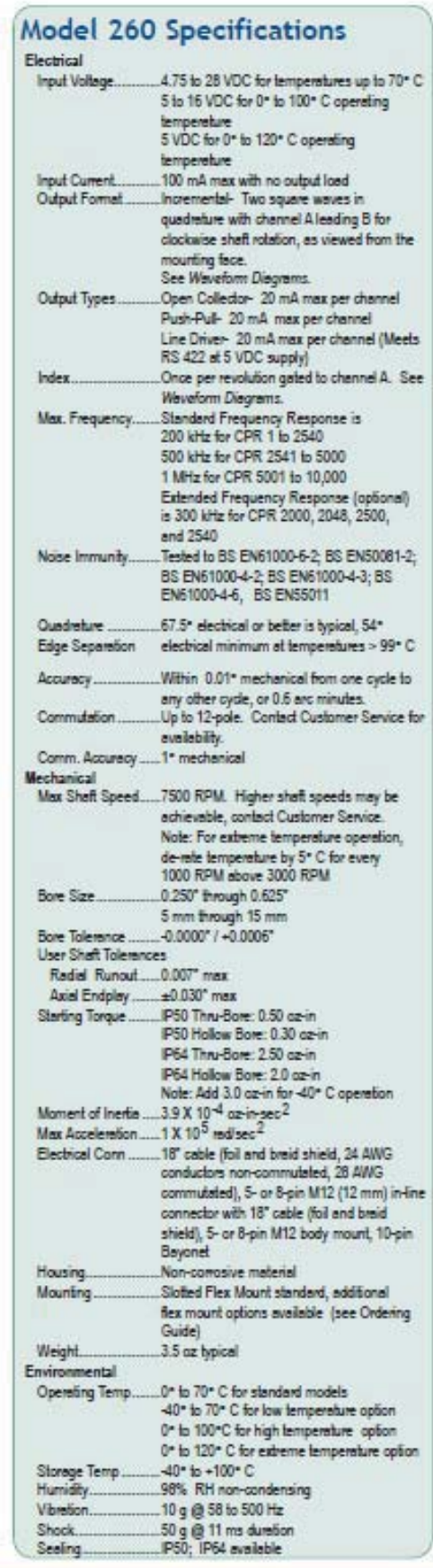

Model 260 With Front Shaft Clamp (T)

With $1.811^{\circ}(46 \mathrm{~mm}) \mathrm{BC}$ Slotted Flex (SF)
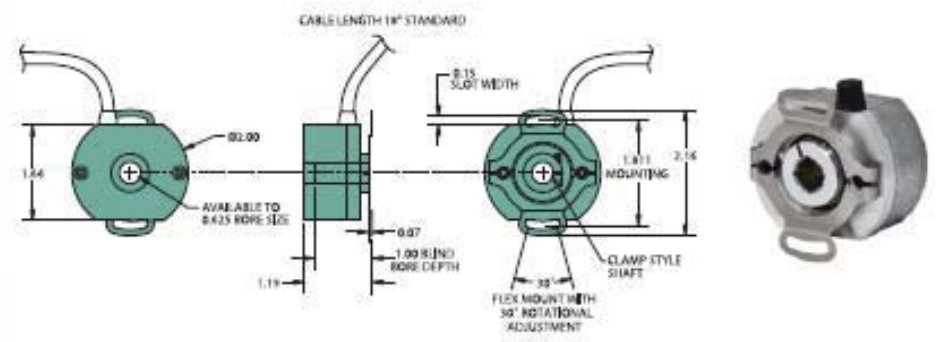

Model 260 Rear Clamp (R)

With $1.811^{*}(46 \mathrm{~mm})$ BC Slotted Flex (SF)
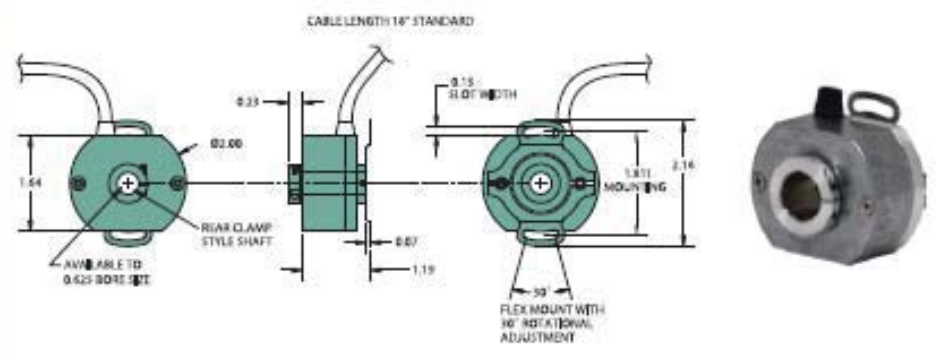

Three Point Flex Mount (XF, NF)
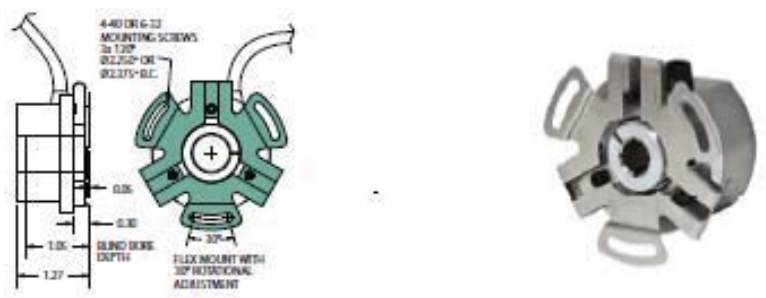

Al dimensions are in inches w th a tolerance of $\leq 0.005^{\circ}$ or $=0.01^{\circ}$ uniess otherwise specifes

1-800-366-5412 - www.encoder.com · sales@encoder.com

Figure C.4: Technical data sheet 2 of shaft encoder. 
$1.575 "$ (40 mm) BC Flex Mount (SD)
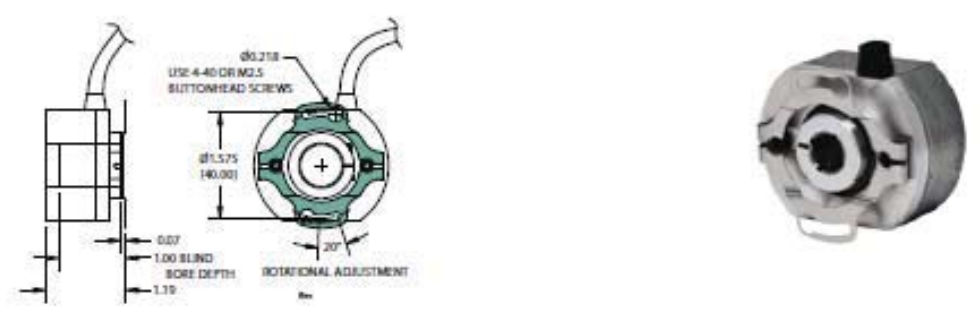

$1.06 "$ to $1.81 "$ Flex Arm (FA)

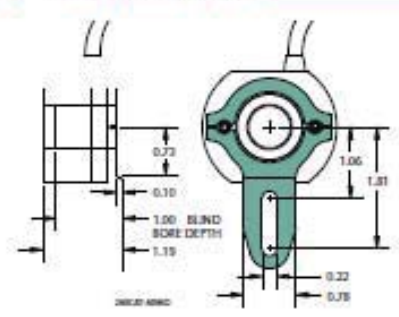

$2.36^{\prime \prime}(60 \mathrm{~mm})$ BC Flex Mount (SL)

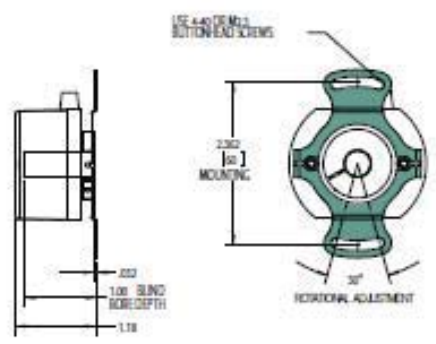

$1.50 "$ to $3.13^{\prime \prime}$ Flex Arm (FB)
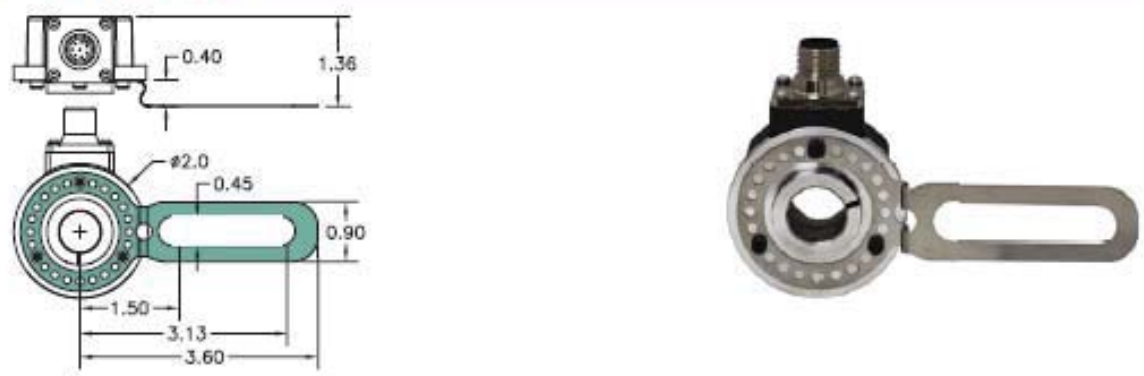

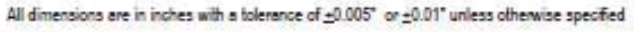

1-800-366-5412 - www.encoder.com · sales@encoder.com

Figure C.5: Technical data sheet 3 of shaft encoder. 
Body Mount 10-pin Bayonet (SMH)

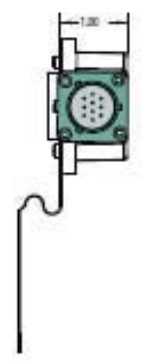

Body Mount M12 (SMJ, SMK)
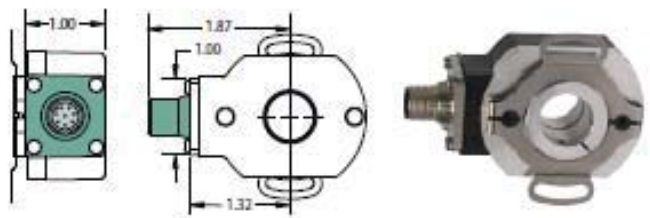

Al dimensions are in inches with a blearce of $=0.005^{\circ}$ or $\$ 0.01$ urless oberwise specfied

Model 260 Connector Options

Waveform Diagrams

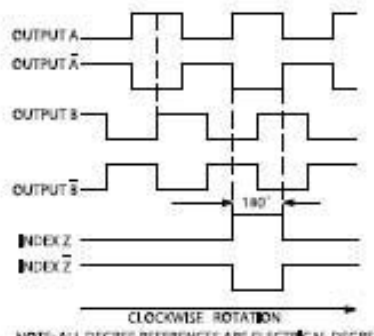

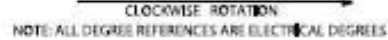

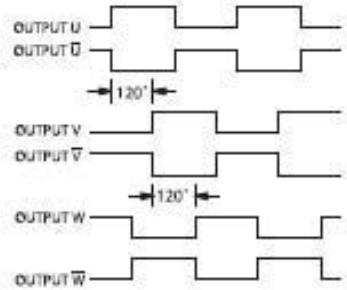

CWRTARONCESATF ASYWED

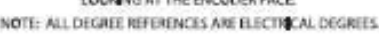

Wiring Table

\begin{tabular}{|c|c|c|c|c|c|}
\hline Function & $\begin{array}{l}\text { Casblo } \\
\text { Winc Color }\end{array}$ & Fon & 19. & \begin{tabular}{|l|} 
TW-pin \\
Bayond
\end{tabular} & \\
\hline Com & Black & 3 & 7 & $F$ & \multirow{11}{*}{ 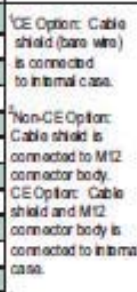 } \\
\hline$+\mathrm{VDC}$ & White & 1 & 2 & 0 & \\
\hline$A$ & Brown & 4 & 1 & $\mathrm{~A}$ & \\
\hline$A^{\prime}$ & Yelow & - & 3 & $\mathrm{H}$ & \\
\hline 8 & Red & 2 & 4 & 8 & \\
\hline$B^{6}$ & Green & - & 5 & J & \\
\hline$z$ & Orange & 5 & 6 & c & \\
\hline$\overline{z^{2}}$ & Bue & $=$ & 8 & $\bar{k}$ & \\
\hline$\overline{0}$ & Viaks & $=$ & $=$ & - & \\
\hline U & Gray & - & 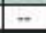 & - & \\
\hline v & Pnik & $=$ & $=$ & $=$ & \\
\hline $\bar{r}$ & Tan & $=$ & $=$ & - & \multirow{4}{*}{$\begin{array}{l}\text { loc Oprorer Pin Gis } \\
\text { comoctod to nnma } \\
\text { case. }\end{array}$} \\
\hline $\bar{W}$ & RedGeen & - & $m$ & - & \\
\hline$w$ & Red/Yelow & - & $m$ & - & \\
\hline Shield & Bage & $=$ & $=$ & - & \\
\hline
\end{tabular}

Connector Pin-Outs

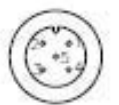

5 Pin

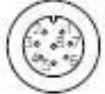

$\mathrm{B}, \mathrm{pin}$
$\mathrm{M} 12$

0.550 MAX HEIGHT
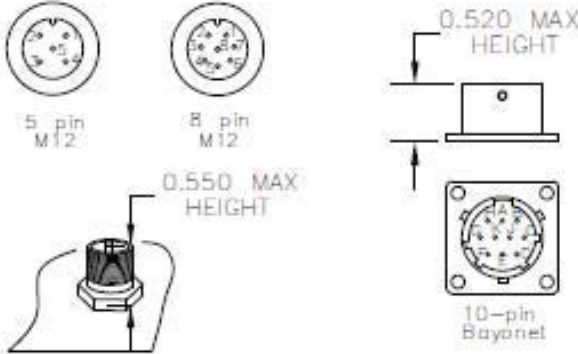

Figure C.6: Technical data sheet 4 of shaft encoder. 


\section{Lambda sensor, LSU 4.9 Measurement of oxygen content}

Input quantity: $\lambda$

Output quantity: U

- The LSU broadband Lambda sensor is a planar $\mathrm{ZrO}_{2}$ two-cell limit current sensor with integral heater.

- It is suitable for measuring the oxygen content and the $\lambda$ value of exhaust gases in vehicle engines.

- A constant characteristic curve in the range from $\lambda=0.65$ to air makes it suitable for universal use for $\lambda=1$ and for other $\lambda$ ranges.

\section{Application}

Engine management

- Block-type thermal power stations

- Diesel engines

- Gasoline engines

- Lean combustion engines

Industrial processes

- Tempering furnaces

- Chemical industry

- Packaging equipment

- Process engineering

- Drying plants

- Metallurgy

Measurement and analysis processes

- Flue gas measurement

- Gas analysis

- Determination of Wobbe

index Incineration plants

- Wood

- Biomass

\section{Design and operation}

The LSU broadband Lambda sensor is a withar $\mathrm{ZrO}_{2}$ two-cell limit current sen measuring the oxygen content and the value of exhaust gases in vehicle engines value of exhaust gases in vehicle
(gasoline and diesel). A constant

characteristic curve in the range from $\lambda=$ characteristic curve in the range from $\lambda=$ 0.65 to air makes it suitable for universal
use for $\lambda=1$ and for other $\lambda$ ranges. The use for $\lambda=1$ and for other $\lambda$ ranges. The
connector module includes a trimming connector module includes a trim resistor, which determines the necessary for the sensor to function. To function, the LSU requires special operating electronics (e.g. AWS. LA4 or IC CJ125 evaluation circuit) and may onty be operated in conjunction with these. The Lambda sensor consists of two cells. It is made up of a Nernst type potentiometric oxygen concentration cell and an amperometric oxygen pump cell. and an amperometric oxygen pump Nernst cells have the property that
oxygen ions diffuse through their ceramic

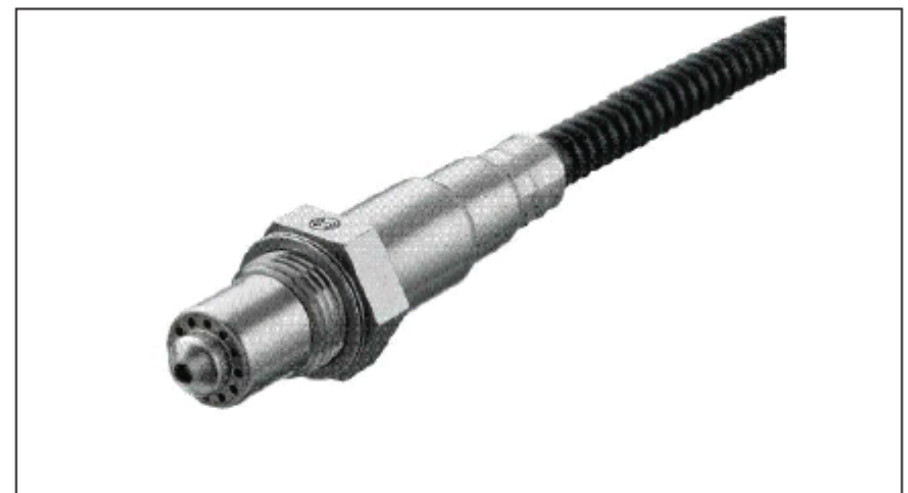

at high temperatures, as soon as there are differences in the partial oxygen pressure at both ends of the ceramic. The transport of ions results in an electrical voltage between them, which is measured using electrodes.

The components of the exhaust gas diffuse through the diffusion duct to the electrodes for the pump and Nernst cell, where they are brought to

thermodynamic equilibrium. Control electronics record the Nernst voltage $U_{N}$ in the concentration cell and supply the pump cell with a variable pump voltage
$U_{p}$. If $U_{N}$ takes on a value of less than 450 $\mathrm{mV}$, the exhaust gas is lean and the pump cell is supplied with a current that causes oxygen to be pumped out of the duct. By contrast, if the exhaust gas is rich, $U_{n}>$ $450 \mathrm{mV}$ and the flow direction is reversed, causing the cell to pump oxygen into the duct.

An integrated module (C.J125) can be used for signal evaluation. As well as the controller for the pump flow and the controller for the pump flow and the controller that keeps the Nernst cell $450 \mathrm{mV}$, t

amplifier

The sensor element is manufactured using thick-film techniques, which results in production distribution. This means that the characteristic curves for different sensors will vary. At an oxygen concentration of $0 \%$, the output voltage is a uniform OV, as when using the evaluation circuit. However, at air the voltage scatters between approx. 6 and 8 V. This means that each sensor has to be individually calibrated so that a clear relationship between the measured oxygen concentration and the output voltage can be created. Calibration can be carried out on air in which the oxygen content is $20.9 \%$. Calibration is

recommended at each maintenance.
Explanation of characteristic quantities

$\lambda \quad$ Air ratio

$U_{\mathrm{N}} \quad$ Nernst voltage

Variable pump voltage

\section{Installation instructions}

- Installation in exhaust pipes at a

location where the exhaust gas

composition is representative whilst

complying with the specified temperature limits.

- The sensor ceramic is rapidly heated when the sensor heating is switched on. After heating of the ceramic, any incidence of condensation water that could damage the hot sensor ceramic is to be ruled out.

- The selected angular installation position should be as close to vertically upwards as possible, but at least 10 from the horizontal. This prevents liquid from accumulating between the sensor housing and the sensor element. An inclination of 90 to the exhaust gas flow is ideal, but the maximum is $90+15$ between the gas inlet hole and the between the gas inlet hole and the exhaust gas flow) or 90 - 30 . Other angular positions are to be evaluated separately where required.

- Tightening torque: $40-60 \mathrm{Nm}$, materia properties and strength of the thread must be designed accordingly.

Robert Bosch GmbH

Automotive Aftermarket

Postfach 410960

76225 Karlsruhe

Germany

www. bosch-sensoren.de

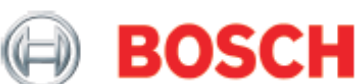

Invented for life

Figure C.7: Technical data sheet 1 of lambda sensor. 


\section{Part number}

\section{Technical data}

\section{Sensor element}

Nominal internal resistance of Nernst cell $R_{i, N}$ when new (operating point, adjustment value), (measurement with $1 . . .4$ $\mathrm{kHz})$ :

Max. current load of Nernst cell Sustained alternating current

( $\mathrm{f}=1 . . .4 \mathrm{kHz}$ ) for $\mathrm{R}_{\mathrm{i}, \mathrm{N}}$ measurement

Recommended reference pump current (sustained)

Max. pump current to pump cell for rich-gas signal $(\lambda \geq 0.65)$

$=20 \mu \mathrm{A}$

Max. pump current to pump cell for lean-gas signal (air)

Heater supply

Nominal voltage

Nominal heating power at $7.5 \mathrm{~V}$ heating voltage in steady-state condition to air

Typical cold resistance of heater at room temperature, including cable and connector

Minimum cold resistance of heater at $-40 \mathrm{C}$

When switching on the heater, the heating power is to be limited as follows:

Heater voltage in condensation-water phase $U_{\text {H.eff }} \leq 2 \mathrm{~V}$

Maximum permissible effective heater voltage $U_{\text {H.eff }}$ to reach short-term operating point $\leq 30 \mathrm{~s}(200 \mathrm{~h}$ cumulative) $\leq 13 \mathrm{~V}$

Maximum permissible effective heater voltage $U_{\text {H.eff }}$ to reach stationary operating point $\leq 12 \mathrm{~V}$

Maximum permissible electrical system voltage $U_{\text {Batt, } \max } \leq 16,5 \mathrm{~V}$

Minimum electrical system voltage $\quad \geq 10,8 \mathrm{~V}$

Operating temperatures

Exhaust gas (T shosis)

Hexagon on sensor housing $T_{\text {Hexagon }}$

作

Cable outlet (PTFE molded hose) - Cable side (upper hose sleeve, $\mathrm{T}_{\text {Upperhose }}$ ) $\leq 200^{\circ} \mathrm{C}$

Cable and protective hose $\quad \leq 250^{\circ} \mathrm{C}$

Connector

Maximum temperatures (max. $250 \mathrm{~h}$ cumulative over service life)

$\leq 1030^{\circ} \mathrm{C}$

Hexagon on sensor housing $T_{H}$

Maximum temperatures ( $\max .40 \mathrm{~h}$ cumulative over service life in intervals of max. $10 \mathrm{~min}$ )

Cable outlet (PTFE molded hose) - Sensor side (PTFE protective sleeve, $T_{\text {Grommet }}$ )

Cable outlet (PTFE molded hose) - Cable side (upper hose sleeve, $\mathrm{T}_{\text {Upperhose }}$ ) $\leq 230^{\circ} \mathrm{C}$

Cable and protective hose $\quad \leq 280^{\circ} \mathrm{C}$

Exhaust-gas back pressure

Continuous service

$\leq 2,5$ bar

Short-term maximum pressure, max. 250 h cumulative over service life

$\leq 4$ bar

Comment:

If the operating temperatures or the permissible exhaust gas back pressure for continuous operation are exceeded, the sensor accuracy is impaired.

Permissible vibration loading

Stochastic vibrations (peak value/peak) $\leq 1000 \mathrm{~m} / \mathrm{s}^{2}$

Sinusoidal vibrations $\leq 300 \mathrm{~m} / \mathrm{s}^{2}$

Standby

Approximate value for sensor switch-on time ("light off")

Figure C.8: Technical data sheet 2 of lambda sensor. 


\section{(A) BOSCH}

Invented for life
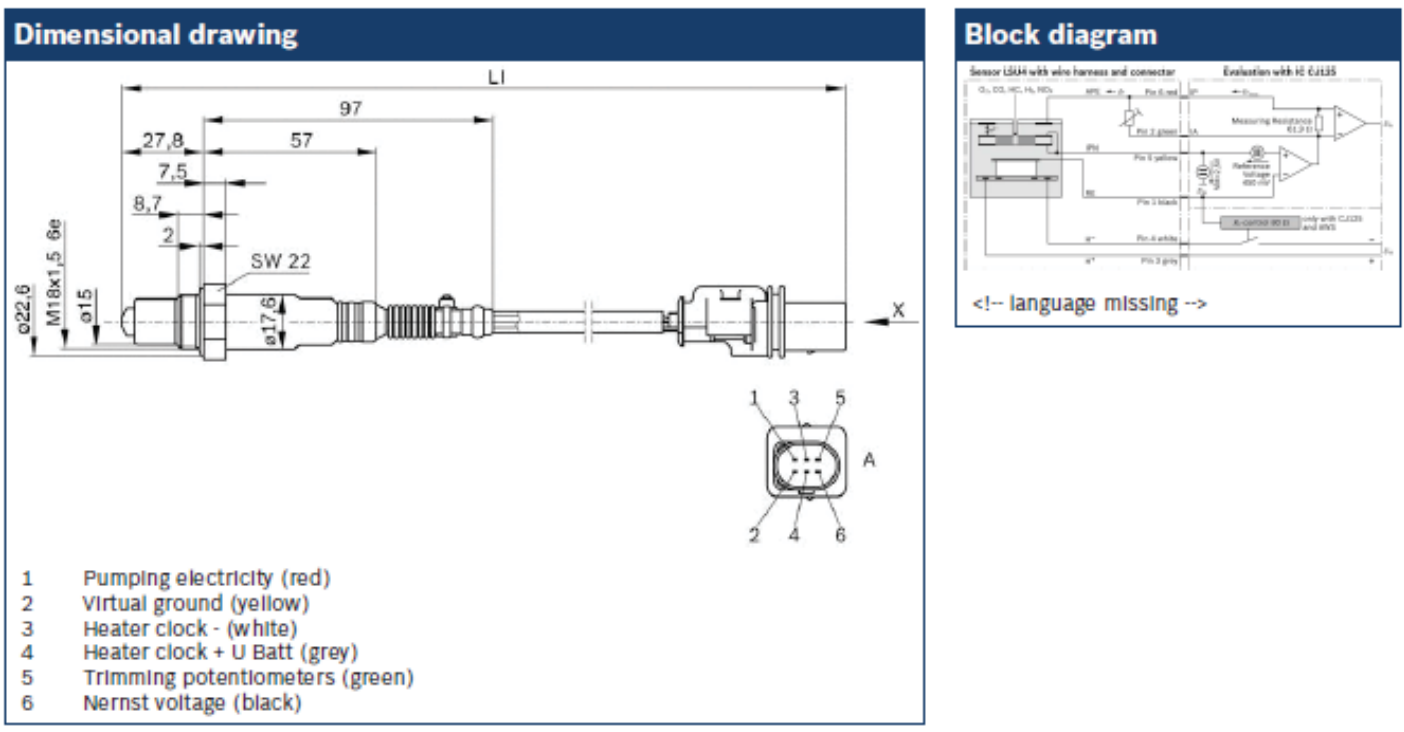

Characteristic curve

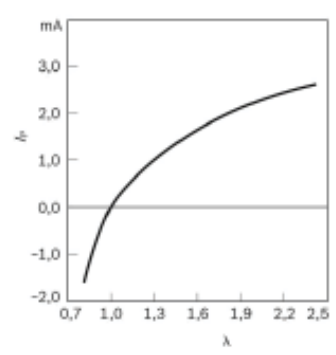

$l_{\mathrm{p}}=$ Pump current

$\lambda=$ Alr ratio

Accessories

Part number

Mating connector parts set

Connector housing, contacts, grommet

1986280016

Figure C.9: Technical data 3 of lambda sensor. 


\section{ANS』 and IEC Color Codes ${ }^{\dagger}$ for Thermocouples, Wire and Connectors}

All OMEGA* Thermocouple Wire, Probes and Connectors are available with either ANSI or IEC Color Codes. In this Handbook, model numbers in the To Order tables reflect the ANSI Color-Coded Product. Please see the next pages for instructions on how to order IEC Color-Coded products.

\begin{tabular}{|c|c|c|c|c|c|c|c|c|c|}
\hline \multirow{2}{*}{$\begin{array}{l}\text { ANSI } \\
\text { Code }\end{array}$} & \multicolumn{2}{|c|}{$\begin{array}{l}\text { ANSI MC } 96.1 \\
\text { Color Coding }\end{array}$} & \multicolumn{2}{|c|}{ Alloy Combination } & \multirow{2}{*}{$\begin{array}{l}\text { Comments } \\
\text { Environment } \\
\text { Bare Wire } \\
\end{array}$} & \multirow{2}{*}{$\begin{array}{c}\text { Maximum } \\
\text { T/C Grade } \\
\text { Temp. } \\
\text { Range }\end{array}$} & \multirow{2}{*}{\begin{tabular}{|c|} 
EMF (mV) \\
Over Max \\
Temp. \\
Range
\end{tabular}} & \multirow{2}{*}{\begin{tabular}{|l|} 
IEC 584-3 \\
Color Coding \\
Ther coeneplo Intringeally \\
Grado
\end{tabular}} & \multirow{2}{*}{$\begin{array}{l}\text { IEC } \\
\text { Code }\end{array}$} \\
\hline & $\begin{array}{l}\text { Thermocouple } \\
\text { Grade }\end{array}$ & $\begin{array}{c}\text { Extension } \\
\text { Grade }\end{array}$ & + Lead & - Lead & & & & & \\
\hline & & & $\begin{array}{c}\underset{1 R O N}{F e} \\
\text { (magnefic) }\end{array}$ & $\begin{array}{l}\text { CONSTANTAN } \\
\text { COPPER- } \\
\text { NIICEL } \\
\text { CUHi } \\
\end{array}$ & 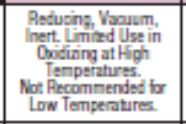 & $\begin{array}{l}-2105012000^{\circ} \\
-346 \text { to } 2193^{\circ}\end{array}$ & $\begin{array}{c}-8.095 \text { to } \\
69.553\end{array}$ & & \\
\hline & & & $\begin{array}{c}\text { CHROMEGN" } \\
\text { NICKELIIM } \\
\text { CHROMUM } \\
N-G \text { Cr }\end{array}$ & $\begin{array}{l}\text { ALOMEGA" } \\
\text { NCKR:- } \\
\text { ALUMNMM } \\
\text { Ni-AI } \\
\text { (magnefic) }\end{array}$ & 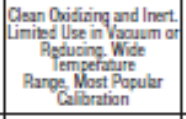 & $\begin{array}{l}-270101372 \% \\
-454 \text { to } 2501 \%\end{array}$ & $\begin{array}{l}-6.4598 \text { to } \\
54.8966\end{array}$ & & \\
\hline & & & COPPER & $\begin{array}{c}\text { CONSTANTAN } \\
\text { COPPER- } \\
\text { NICEEL } \\
\text { CUANE }\end{array}$ & 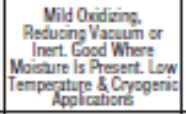 & $\begin{array}{l}-270 \text { in } 400^{\circ} \mathrm{C} \\
-454 \text { to } 752^{\circ} \mathrm{F}\end{array}$ & $\frac{-6.258 \text { tD }}{20.872}$ & & \\
\hline & & & 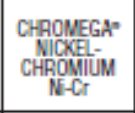 & 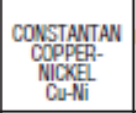 & 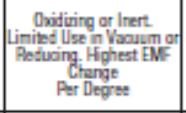 & $\begin{array}{l}-270 \text { to } 10000 \mathrm{c} \\
-454 \mathrm{tb} 1832 \mathrm{~F}\end{array}$ & $\frac{-9.925 \text { to }}{76.373}$ & & \\
\hline & & & $\begin{array}{l}\text { OMEGA.P. } \\
\text { MICAOSIL } \\
\text { Mi-CT-Si }\end{array}$ & 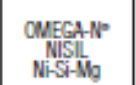 & 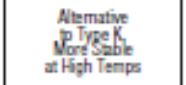 & $\begin{array}{l}-270010130006 \\
-450 \text { to } 2372 \%\end{array}$ & $\begin{array}{l}-4.245 \\
\text { to } 47.513\end{array}$ & & \\
\hline & $\begin{array}{c}\text { NONE } \\
\text { ESTABLISHED }\end{array}$ & & $\begin{array}{l}\text { PLATINUM- } \\
\text { 13\% RHODLUM } \\
\text { P1-13\% Ph }\end{array}$ & PLATINUM & 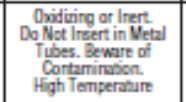 & $\begin{array}{l}-60 \text { to } 1762 \% \mathrm{C} \\
-58 \text { to } 3214 \%\end{array}$ & $\begin{array}{l}-0.226 \\
\text { to } 21.101\end{array}$ & & 3 \\
\hline & $\begin{array}{c}\text { NONE } \\
\text { ESTABLISHED }\end{array}$ & & $\begin{array}{l}\text { PLATINUM- } \\
10 \% \text { RHODIUM } \\
\text { Ph-10\% Ph }\end{array}$ & $\underset{P t}{\text { PLATINUM }}$ & 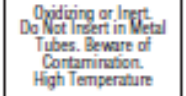 & $\begin{array}{l}-60 \text { to } 176 \% \mathrm{C} \\
-58 \text { to } 3214 \% \mathrm{~F}\end{array}$ & $\begin{array}{l}-0.236 \\
\text { to } 18.693\end{array}$ & & 8 \\
\hline & $\begin{array}{c}\text { NONE } \\
\text { ESTABLISHED }\end{array}$ & & COPPER & $\begin{array}{c}\text { COPPER-LOW } \\
\text { NICKEL } \\
\text { Cu-Ni }\end{array}$ & 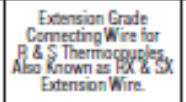 & & & & \\
\hline & $\begin{array}{c}\text { NONE } \\
\text { ESTABLISHED }\end{array}$ & & $\begin{array}{l}\text { PLATINUM- } \\
\text { 30\% PAODOLM } \\
\text { PA-30\% Rh }\end{array}$ & $\begin{array}{l}\text { PLATINUM } \\
\text { 6\% RHOOIUM } \\
\text { Pi-6\% Rh }\end{array}$ & 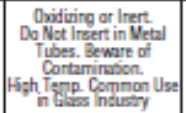 & $\begin{array}{l}01010200 \mathrm{C} \\
32+03008 \%\end{array}$ & 0 to 13.820 & & \\
\hline $\mathrm{C}^{*}$ & $\begin{array}{c}\text { NONE } \\
\text { ESTABLISHED }\end{array}$ & & TUNGSTEN & $\begin{array}{l}\text { TUNGSTEV- } \\
\text { 26\% RHENIUM } \\
\text { W-26\% } \mathrm{He}\end{array}$ & 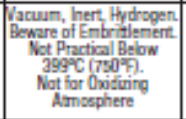 & $\begin{array}{l}0 \text { to } 223000 \\
32 \text { in } 4208 \%\end{array}$ & 0 to 38.564 & $\begin{array}{l}\text { NOSTANDARD } \\
\text { USEANSSI } \\
\text { COLOR CODE }\end{array}$ & ) \\
\hline $\mathrm{C}^{\mathrm{W} 5}$ * & $\begin{array}{c}\text { NONE } \\
\text { ESTABLISHED }\end{array}$ & & $\begin{array}{l}\text { TUNGSTEY } \\
\text { 5\% RHENIUM } \\
\text { W-5\% } \mathrm{Re}\end{array}$ & \begin{tabular}{|c|} 
TUNGSTEN- \\
26\% RHENIUM \\
W-26\% $\mathrm{Re}$ \\
\end{tabular} & 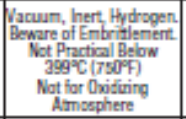 & $\begin{array}{l}0 \text { to } 23200^{\circ} \mathrm{C} \\
32 \text { to } 42008^{\circ}\end{array}$ & 0 to 37.065 & $\begin{array}{l}\text { NO STANDAAD } \\
\text { USEARSI } \\
\text { COLOR CODE }\end{array}$ & (W5) \\
\hline${ }_{(\mathrm{W} 3)}^{*}$ & $\begin{array}{c}\text { NONE } \\
\text { ESTABLISHED }\end{array}$ & & $\begin{array}{l}\text { TUNGSTEN- } \\
\text { 3\% RHENUIM } \\
\text { W-3\% Ra }\end{array}$ & \begin{tabular}{|c|} 
TUNGSTEN- \\
25\% RHENUM \\
W-25\% $\mathrm{Ae}$
\end{tabular} & 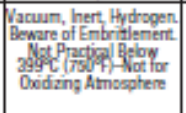 & $\begin{array}{l}0 \text { to } 232000 \mathrm{C} \\
32 \text { to } 42000^{\circ}\end{array}$ & 0 to 39.505 & $\begin{array}{l}\text { NO STANDARD } \\
\text { USE ANISS } \\
\text { COLOR CODE }\end{array}$ & $\underset{(\mathrm{W} 3)}{D}$ \\
\hline
\end{tabular}

- Not official symbol or standard designation

t JIS color code also available.

H-3

Figure C.10: Technical data sheet 1 of thermocouple. 


\section{Thermocouple Tolerances (Reference Junction at $0^{\circ} \mathrm{C}$ )}

\begin{tabular}{|c|c|c|c|c|c|}
\hline \multicolumn{2}{|l|}{ ANSI Code } & \multicolumn{2}{|c|}{ Standard Limits ${ }^{\dagger}$} & \multicolumn{2}{|c|}{ Special Limits $^{\dagger}$} \\
\hline & $\begin{array}{c}\text { Temp Range } \\
\text { Tolerance Value } \\
\end{array}$ & $\begin{array}{c}>0 \text { to } 750^{\circ} \mathrm{C} \\
2.2^{\circ} \mathrm{C} \text { or } 0.75 \% \\
\end{array}$ & $\begin{array}{l}>32 \text { to } 1382^{\circ} \mathrm{F} \\
4.0^{\circ} \mathrm{F} \text { or } 0.75 \% \\
\end{array}$ & $\begin{array}{c}0 \text { to } 750^{\circ} \mathrm{C} \\
1.1^{\circ} \mathrm{C} \text { or } 0.4 \% \\
\end{array}$ & $\begin{array}{l}32 \text { to } 1382^{\circ} \mathrm{F} \\
2.0^{\circ} \mathrm{F} \text { or } 0.4 \% \\
\end{array}$ \\
\hline & $\begin{array}{l}\text { Temp Range } \\
\text { Tolerance Value } \\
\text { Temp. Range } \\
\text { Tolerance Value } \\
\end{array}$ & $\begin{array}{l}>0 \text { to } 1250^{\circ} \mathrm{C} \\
2.2^{\circ} \mathrm{C} \text { or } 0.75 \% \\
-200 \text { to } 0^{\circ} \mathrm{C} \\
2.2^{\circ} \mathrm{C} \text { or } 2.0 \%\end{array}$ & $\begin{array}{l}>32 \text { to } 2282^{\circ} \mathrm{F} \\
4.0^{\circ} \mathrm{F} \text { or } 0.75 \% \\
-328 \text { to } 32^{\circ} \mathrm{F} \\
4.0^{\circ} \mathrm{F} \text { or } 2.0 \%\end{array}$ & $\begin{array}{l}0 \text { to } 1250^{\circ} \mathrm{C} \\
1.1^{\circ} \mathrm{C} \text { or } 0.4 \%\end{array}$ & $\begin{array}{l}32 \text { to } 2282^{\circ} \mathrm{F} \\
2.0^{\circ} \mathrm{F} \text { or } 0.4 \%\end{array}$ \\
\hline & $\begin{array}{l}\text { Temp Range } \\
\text { Tolerance Value } \\
\text { Temp. Range } \\
\text { Tolerance Value } \\
\end{array}$ & $\begin{array}{l}>0 \text { to } 350^{\circ} \mathrm{C} \\
1.0^{\circ} \mathrm{C} \text { or } 0.75 \% \\
-200 \text { to } 0^{\circ} \mathrm{C} \\
1.0^{\circ} \mathrm{C} \text { or } 1.5 \%\end{array}$ & $\begin{array}{l}>32 \text { to } 662^{\circ} \mathrm{F} \\
1.8^{\circ} \mathrm{F} \text { or } 0.75 \% \\
-328 \text { to } 32^{\circ} \mathrm{F} \\
1.8^{\circ} \mathrm{F} \text { or } 1.5 \%\end{array}$ & $\begin{array}{l}0 \text { to } 350^{\circ} \mathrm{C} \\
0.5^{\circ} \mathrm{C} \text { or } 0.4 \%\end{array}$ & $\begin{array}{l}32 \text { to } 662^{\circ} \mathrm{F} \\
1^{\circ} \mathrm{F} \text { or } 0.4 \%\end{array}$ \\
\hline & $\begin{array}{l}\text { Temp Range } \\
\text { Tolerance Value } \\
\text { Temp. Range } \\
\text { Tolerance Value }\end{array}$ & $\begin{array}{c}>0 \text { to } 900^{\circ} \mathrm{C} \\
1.7^{\circ} \mathrm{C} \text { or } 0.5 \% \\
-200 \text { to } 0^{\circ} \mathrm{C} \\
1.7^{\circ} \mathrm{C} \text { or } 1.0 \%\end{array}$ & $\begin{array}{l}>32 \text { to } 1652 \\
3^{\circ} \mathrm{F} \text { or } 0.5 \% \\
-328 \text { to } 32^{\circ} \mathrm{F} \\
3^{\circ} \mathrm{F} \text { or } 1.0 \%\end{array}$ & $\begin{array}{c}0 \text { to } 900^{\circ} \mathrm{C} \\
1.0^{\circ} \mathrm{C} \text { or } 0.4 \%\end{array}$ & $\begin{array}{l}32 \text { to } 1652^{\circ} \mathrm{F} \\
1.8^{\circ} \mathrm{F} \text { or } 0.4 \%\end{array}$ \\
\hline & $\begin{array}{l}\text { Temp Range } \\
\text { Tolerance Value } \\
\text { Temp. Range } \\
\text { Tolerance Value }\end{array}$ & $\begin{array}{c}>0 \text { to } 1300^{\circ} \mathrm{C} \\
2.2^{\circ} \mathrm{C} \text { or } 0.75 \% \\
-270 \text { to } 0^{\circ} \mathrm{C} \\
2.2^{\circ} \mathrm{C} \text { or } 2.0 \%\end{array}$ & $\begin{array}{l}>32 \text { to } 2372^{\circ} \mathrm{F} \\
4.0^{\circ} \mathrm{F} \text { or } 0.75 \% \\
-454 \text { to } 32^{\circ} \mathrm{F} \\
4.0^{\circ} \mathrm{F} \text { or } 2.0 \%\end{array}$ & $\begin{array}{l}0 \text { to } 1300^{\circ} \mathrm{C} \\
1.1^{\circ} \mathrm{C} \text { or } 0.4 \%\end{array}$ & $\begin{array}{l}32 \text { to } 2372^{\circ} \mathrm{F} \\
2.0^{\circ} \mathrm{F} \text { or } 0.4 \%\end{array}$ \\
\hline$R S$ & $\begin{array}{l}\text { Temp Range } \\
\text { Tolerance Value }\end{array}$ & $\begin{array}{c}0 \text { to } 1450^{\circ} \mathrm{C} \\
1.5^{\circ} \mathrm{C} \text { or } 0.25 \%\end{array}$ & $\begin{array}{c}32 \text { to } 2642^{\circ} \mathrm{F} \\
2.7^{\circ} \mathrm{F} \text { or } 0.25 \%\end{array}$ & $\begin{array}{l}0 \text { to } 1450^{\circ} \mathrm{C} \\
0.6^{\circ} \mathrm{C} \text { or } 0.1 \%\end{array}$ & $\begin{array}{l}32 \text { to } 2642^{\circ} \mathrm{F} \\
1^{\circ} \mathrm{F} \text { or } 0.1 \%\end{array}$ \\
\hline D & $\begin{array}{l}\text { Temp Range } \\
\text { Tolerance Value }\end{array}$ & $\begin{array}{l}800 \text { to } 1700^{\circ} \mathrm{C} \\
0.5 \%\end{array}$ & $\begin{array}{c}1472 \text { to } 3092^{\circ} \mathrm{F} \\
0.5 \%\end{array}$ & \multicolumn{2}{|c|}{$\begin{array}{c}\text { Not } \\
\text { Established }\end{array}$} \\
\hline & $\begin{array}{l}\text { Temp Range } \\
\text { Tolerance Value }\end{array}$ & $\begin{array}{c}0 \text { to } 2320^{\circ} \mathrm{C} \\
4.5^{\circ} \mathrm{C} \text { or } 1.0 \%\end{array}$ & $\begin{array}{l}32 \text { to } 4208^{\circ} \mathrm{F} \\
9^{\circ} \mathrm{F} \text { or } 1.0 \%\end{array}$ & \multicolumn{2}{|c|}{$\begin{array}{c}\text { Not } \\
\text { Established }\end{array}$} \\
\hline
\end{tabular}

* Not official symbol or standard de signation t Whichever value is greater.

Note: Material is normally selected to meet tolerances above $0^{\circ} \mathrm{C}$. If thermocouples are needed to meet tolerances below $0^{\circ} \mathrm{C}$, the purchaser shall state this as selection of material is usually required.

IEC Tolerance Class EN 60584-2; JIS C 1602

\begin{tabular}{|c|c|c|c|c|}
\hline IEC Code & & Class 1 & Class 2 & Class $3^{\text {tt }}$ \\
\hline & $\begin{array}{c}\text { Temp Range } \\
\text { Tolerance Value } \\
\text { Temp. Range } \\
\text { Tolerance Value } \\
\end{array}$ & $\begin{array}{c}-40 \text { to } 375^{\circ} \mathrm{C} \\
\pm 1.5^{\circ} \mathrm{C} \\
375^{\circ} \text { to } 750^{\circ} \mathrm{C} \\
\pm 0.4 \% \text { Reading }\end{array}$ & $\begin{array}{c}-40 \text { to } 333^{\circ} \mathrm{C} \\
\pm 2.5^{\circ} \mathrm{C} \\
333 \text { to } 750^{\circ} \mathrm{C} \\
\pm 0.75 \% \text { Reading }\end{array}$ & $\begin{array}{c}\text { Not } \\
\text { Established }\end{array}$ \\
\hline & $\begin{array}{l}\text { Temp Range } \\
\text { Tolerance Value } \\
\text { Temp. Range } \\
\text { Tolerance Value } \\
\end{array}$ & $\begin{array}{c}-40 \text { to } 375^{\circ} \mathrm{C} \\
\pm 1.5^{\circ} \mathrm{C} \\
375^{\circ} \text { to } 10000^{\circ} \mathrm{C} \\
\pm 0.4 \%\end{array}$ & $\begin{array}{c}-40 \text { to } 333^{\circ} \mathrm{C} \\
\pm 2.5^{\circ} \mathrm{C} \\
333 \text { to } 1200^{\circ} \mathrm{C} \\
\pm 0.75 \% \text { Reading } \\
\end{array}$ & $\begin{array}{c}-167 \text { to } 40^{\circ} \mathrm{C} \\
\pm 2.5^{\circ} \mathrm{C} \\
-200 \text { to }-167^{\circ} \mathrm{C} \\
\pm 1.5 \% \text { Reading } \\
\end{array}$ \\
\hline & $\begin{array}{l}\text { Temp Range } \\
\text { Tolerance Value } \\
\text { Temp. Range } \\
\text { Tolerance Value } \\
\end{array}$ & $\begin{array}{c}-40 \text { to } 125^{\circ} \mathrm{C} \\
\pm 0.5^{\circ} \mathrm{C} \\
125 \text { to } 350^{\circ} \mathrm{C} \\
\pm 0.4 \% \text { Peading }\end{array}$ & $\begin{array}{c}-40 \text { to } 133^{\circ} \mathrm{C} \\
\pm 1^{1} \mathrm{C} \\
133 \text { to } 350^{\circ} \mathrm{C} \\
\pm 0.75 \% \text { Reading } \\
\end{array}$ & $\begin{array}{c}-67 \text { to } 40^{\circ} \mathrm{C} \\
\pm 1^{\circ} \mathrm{C} \\
-200 \text { to }-67^{\circ} \mathrm{C} \\
\pm 1.5 \% \text { Reading }\end{array}$ \\
\hline$=$ & $\begin{array}{l}\text { Temp Range } \\
\text { Tolerance Value } \\
\text { Temp. Range } \\
\text { Tolerance Value }\end{array}$ & $\begin{array}{c}-40 \text { to } 375^{\circ} \mathrm{C} \\
\pm 1.5^{\circ} \mathrm{C} \\
375 \text { to } 800^{\circ} \mathrm{C} \\
\pm 0.4 \% \text { Reading }\end{array}$ & $\begin{array}{c}-40 \text { to } 333^{\circ} \mathrm{C} \\
\pm 2.5^{\circ} \mathrm{C} \\
333 \text { to } 900^{\circ} \mathrm{C} \\
\pm 0.75 \% \text { Reading }\end{array}$ & $\begin{array}{c}-167 \text { to } 40^{\circ} \mathrm{C} \\
\pm 2.5^{\circ} \mathrm{C} \\
-200 \text { to }-167^{\circ} \mathrm{C} \\
\pm 1.5 \% \text { Reading }\end{array}$ \\
\hline$R S$ & $\begin{array}{c}\text { Temp Range } \\
\text { Tolerance Value } \\
\text { Temp. Range } \\
\text { Tolerance Value } \\
\end{array}$ & $\begin{array}{c}0 \text { to } 1100^{\circ} \mathrm{C} \\
\pm 1^{\circ} \mathrm{C} \\
1100 \text { to } 1600^{\circ} \mathrm{C} \\
\pm[1+0.3 \% \times(\text { Rdg }-1100)]^{\circ} \mathrm{C}\end{array}$ & $\begin{array}{c}0 \text { to } 600^{\circ} \mathrm{C} \\
\pm 1.5^{\circ} \mathrm{C} \\
600 \text { to } 1600^{\circ} \mathrm{C} \\
\pm 0.25 \% \text { Reading }\end{array}$ & $\begin{array}{l}\text { Not } \\
\text { Established }\end{array}$ \\
\hline B & $\begin{array}{c}\text { Temp Range } \\
\text { Tolerance Value } \\
\text { Temp. Range } \\
\text { Tolerance Value }\end{array}$ & $\begin{array}{c}\text { Not } \\
\text { Established }\end{array}$ & $\begin{array}{c}600 \text { to } 1700^{\circ} \mathrm{C} \\
\pm 0.25 \% \text { Reading }\end{array}$ & $\begin{array}{l}600 \text { to } 800^{\circ} \mathrm{C} \\
\quad+4^{\circ} \mathrm{C} \\
800 \text { to } 1700^{\circ} \mathrm{C} \\
\pm 0.5 \% \text { Reading }\end{array}$ \\
\hline
\end{tabular}

H Material is normally selected to meet tolerances above $-40^{\circ} \mathrm{C}$. If thermocouples are needed to meet limits of Class 3 , as well as those of Class 1 or 2, the purchaser shall state this, as selection of material is usually required.

H-4

Figure C.11: Technical data sheet 3 of thermocouple. 


\section{Wire Insulation Identification}

\begin{tabular}{|c|c|c|c|c|c|c|c|}
\hline \multirow{2}{*}{$\begin{array}{l}\text { Insulation } \\
\text { Code }\end{array}$} & \multicolumn{2}{|c|}{ Insulation } & \multirow{2}{*}{$\begin{array}{c}\text { Appearance of } \\
\text { Thermocouple Grade Wire }\end{array}$} & \multirow{2}{*}{$\begin{array}{c}\text { Temperature } \\
\text { Range, } \\
\text { Insulation }\end{array}$} & \multirow{2}{*}{$\begin{array}{c}\text { Abrasion } \\
\text { Resistance }\end{array}$} & \multirow{2}{*}{ Flexibility } & \multirow{2}{*}{$\begin{array}{c}\text { Water } \\
\text { Submersion }\end{array}$} \\
\hline & Overall & Conductors & & & & & \\
\hline & $\begin{array}{l}\text { Polyvinyl } \\
\text { Chloride } \\
\text { (PVC) }\end{array}$ & $\begin{array}{l}\text { Polyvinyl } \\
\text { Chloride } \\
\text { (PVC) }\end{array}$ & & $\begin{array}{l}-40 \text { to } 105^{\circ} \mathrm{C} \\
-40 \text { to } 221^{\circ} \mathrm{F}\end{array}$ & Good & Excellent & Good \\
\hline & $\begin{array}{l}\text { FEP } \\
\text { Teflon or or } \\
\text { Neoflon }\end{array}$ & $\begin{array}{l}\text { FEP } \\
\text { Teflon* or } \\
\text { Neofion }\end{array}$ & & $\begin{array}{l}-200 \text { to } 200^{\circ} \mathrm{C} \\
-338 \text { to } 392^{\circ} \mathrm{F}\end{array}$ & Excellent & Good & Excellent \\
\hline & $\begin{array}{l}\text { PFA } \\
\text { Teflon" or } \\
\text { Neoflon }\end{array}$ & $\begin{array}{l}\text { PFA } \\
\text { Teflone or } \\
\text { Neoflon }\end{array}$ & & $\begin{array}{l}-267 \text { to } 260^{\circ} \mathrm{C} \\
-450 \text { to } 500^{\circ} \mathrm{F}\end{array}$ & Excellent & Good & Excellent \\
\hline & Kapton & Kapton & & $\begin{array}{l}-267 \text { to } 316^{\circ} \mathrm{C} \\
-450 \text { to } 600^{\circ} \mathrm{F}\end{array}$ & Excellent & Good & Good \\
\hline & $\begin{array}{l}\text { Glass } \\
\text { Braid }\end{array}$ & $\begin{array}{l}\text { PFA } \\
\text { Teflone or } \\
\text { Neofion }\end{array}$ & & $\begin{array}{l}-73 \text { to } 260^{\circ} \mathrm{C} \\
-100 \text { to } 500^{\circ} \mathrm{F}\end{array}$ & Good & Good & Excellent \\
\hline ExGla] & $\begin{array}{l}\text { Glass } \\
\text { Braid }\end{array}$ & $\begin{array}{l}\text { Glass } \\
\text { Braid }\end{array}$ & & $\begin{array}{l}-73 \text { to } 482^{\circ} \mathrm{C} \\
-100 \text { to } 900^{\circ} \mathrm{F}\end{array}$ & Poor & Good & Poor \\
\hline & $\begin{array}{l}\text { High Temp } \\
\text { Glass } \\
\text { Braid }\end{array}$ & $\begin{array}{l}\text { High Temp } \\
\text { Glass } \\
\text { Braid }\end{array}$ & & $\begin{array}{c}-73 \text { to } 704^{\circ} \mathrm{C} \\
-100 \text { to } 1300^{\circ} \mathrm{F}\end{array}$ & Poor & Good & Poor \\
\hline & $\begin{array}{l}\text { Refrasil } \\
\text { Braid }\end{array}$ & $\begin{array}{l}\text { Refrasil } \\
\text { Braid }\end{array}$ & & $\begin{array}{c}-73 \text { to } 871^{\circ} \mathrm{C} \\
-100 \text { to } 1600^{\circ} \mathrm{F}\end{array}$ & Poor & $\begin{array}{c}\text { Good to } \\
315^{\circ} \mathrm{C}\left(600^{\circ} \mathrm{F}\right)\end{array}$ & $\begin{array}{c}\text { Poor to } \\
315^{\circ} \mathrm{C}\left(600^{\circ} \mathrm{F}\right)\end{array}$ \\
\hline $\begin{array}{l}\text { Standard Braid } \\
\text { Xla-Lose Brad } \\
\text { XT-Tight Braid }\end{array}$ & $\begin{array}{l}\text { Nextel } \\
\text { Braid }\end{array}$ & $\begin{array}{l}\text { Nextel } \\
\text { Braid }\end{array}$ & & $\begin{array}{l}-73 \text { to } 1204^{\circ} \mathrm{C} \\
-100 \text { to } 2200^{\circ} \mathrm{F}\end{array}$ & Poor & Good & Poor \\
\hline & Silica & Silica & 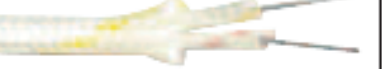 & $\begin{array}{l}-73 \text { to } 1038^{\circ} \mathrm{C} \\
-100 \text { to } 1990^{\circ} \mathrm{F}\end{array}$ & Poor & Good & Poor \\
\hline & $\begin{array}{l}\text { TFE } \\
\text { Teflon }\end{array}$ & $\begin{array}{c}\text { TFE } \\
\text { Teflon" }\end{array}$ & & $\begin{array}{l}-267 \text { to } 260^{\circ} \mathrm{C} \\
-450 \text { to } 500^{\circ} \mathrm{F}\end{array}$ & Excellent & Good & Excellent \\
\hline
\end{tabular}

Figure C.12: Technical data sheet 3 of thermocouple. 


\section{and Application Guide}

\begin{tabular}{|c|c|c|c|c|c|}
\hline \multicolumn{5}{|c|}{ Resistance To: } & \multirow{2}{*}{ Comments } \\
\hline Solvent & Acid & Base & Flame & Humidity & \\
\hline Fair & Good & Good & Good & Good & $\begin{array}{l}\text { Color Coded PVC Extruded Over Each Bare } \\
\text { Wire. PVC Applled Over Insulated Primarlas. } \\
\text { Aftected by Ketones, Esters }\end{array}$ \\
\hline Excellent & Excellent & Excellent & Excellent & Excellent & $\begin{array}{c}\text { Color Coded PVC Extruded Over Each Bare Wire. } \\
\text { PVC Applled Over Insulated Primarles. Affected by } \\
\text { Ketonas, Esters }\end{array}$ \\
\hline Excellent & Excellent & Excellent & Excellent & Excellent & $\begin{array}{l}\text { Color Coded PFA Extrudad Over Each Bare Wre. PFA } \\
\text { Jacket Extruded Over Insulated Primarles. Superior } \\
\text { Abrasion and Molsture Resistance. Same Basic } \\
\text { Characteristics as FEP but Higher Temperature Rating }\end{array}$ \\
\hline Good & Good & Good & Good & Excellent & 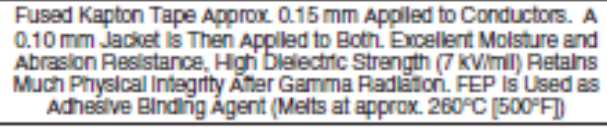 \\
\hline Excellent & Excellent & Excellent & Excellent & Excellent & $\begin{array}{c}\text { PFA Extrudad Over Each Bare Wre and a Glass Brald } \\
\text { on the Jacket. May Be Used for Single Maasurement } \\
\text { to } 343^{\circ} \mathrm{C}\left(650^{\circ} \mathrm{F}\right)\end{array}$ \\
\hline Excellent & Excellent & Excellent & Excellent & Fair & $\begin{array}{l}0.12 \text { mm Glass Brald Over Each Conductor, and Binder } \\
\text { Impregnated. Overall Glass Braid Appled and } \\
\text { Bindered. Binder Improves Molsture and Abrasion } \\
\text { Rasistance but Is Destroyed Above } 204^{\circ} \mathrm{C}\left(400^{\circ} \mathrm{F}\right)\end{array}$ \\
\hline Excellent & Excellent & Excellent & Excellent & Fair & $\begin{array}{l}\text { High Temp. Glass Brald Over Each Conductor, and } \\
\text { Binder Impregnated. Overal High Temp Glass Brald } \\
\text { Appled and Bindered. Binder Improves Molsture and } \\
\text { Abraslon Reslstance but Is Destroyed Above } 400^{\circ} \mathrm{F}\end{array}$ \\
\hline Excellent & $\begin{array}{c}\text { Good to } \\
315^{\circ} \mathrm{C}\left(600^{\circ} \mathrm{F}\right)\end{array}$ & $\begin{array}{l}\text { Good to } \\
315^{\circ} \mathrm{C}\left(600^{\circ} \mathrm{F}\right)\end{array}$ & Excellent & Poor & $\begin{array}{l}\text { Brald of Vitreous Sllica Fiber Appled to Each } \\
\text { Bare Wire, Then Over Both. Sultable to } 982^{\circ} \mathrm{C}\left(1800^{\circ} \mathrm{F}\right) \\
\text { If Not Subjected to Flexure or Abrasion }\end{array}$ \\
\hline Excellent & Good & Good & Excellent & Fair & $\begin{array}{l}\text { High Temp, Alumina-Borla-Sillca Ceramic Fiber Bralded } \\
\text { Over Each Conductor Then Over Both. Not Recommended } \\
\text { for Platinum Themocouples or Exposure to Molten Tin and } \\
\text { Copper, Hydrofluoric or Phosphoric Aclds, or Strong Alkallas }\end{array}$ \\
\hline Excellent & Good & Poor & Excellent & Fair & $\begin{array}{l}\text { Sillca Is a Very High Purity, Chemically } \\
\text { Stable Yarn. (SiO2 Content 99\%) }\end{array}$ \\
\hline Excellent & Excellent & Excellent & Excellent & Excellent & $\begin{array}{l}\text { Color Coded TFE Tape Applled to Conductors } \\
\text { and Jacket. Superior Abrasion, Molsture, and } \\
\text { Chemical Resistance. }\end{array}$ \\
\hline
\end{tabular}

Figure C.13: Technical data sheet 4 of thermocouple. 


\section{INDUSTRIAL GRADE PRESSURE TRANSDUCER Models 111, 211, 311}

\section{Custom Engineered to fit your application}

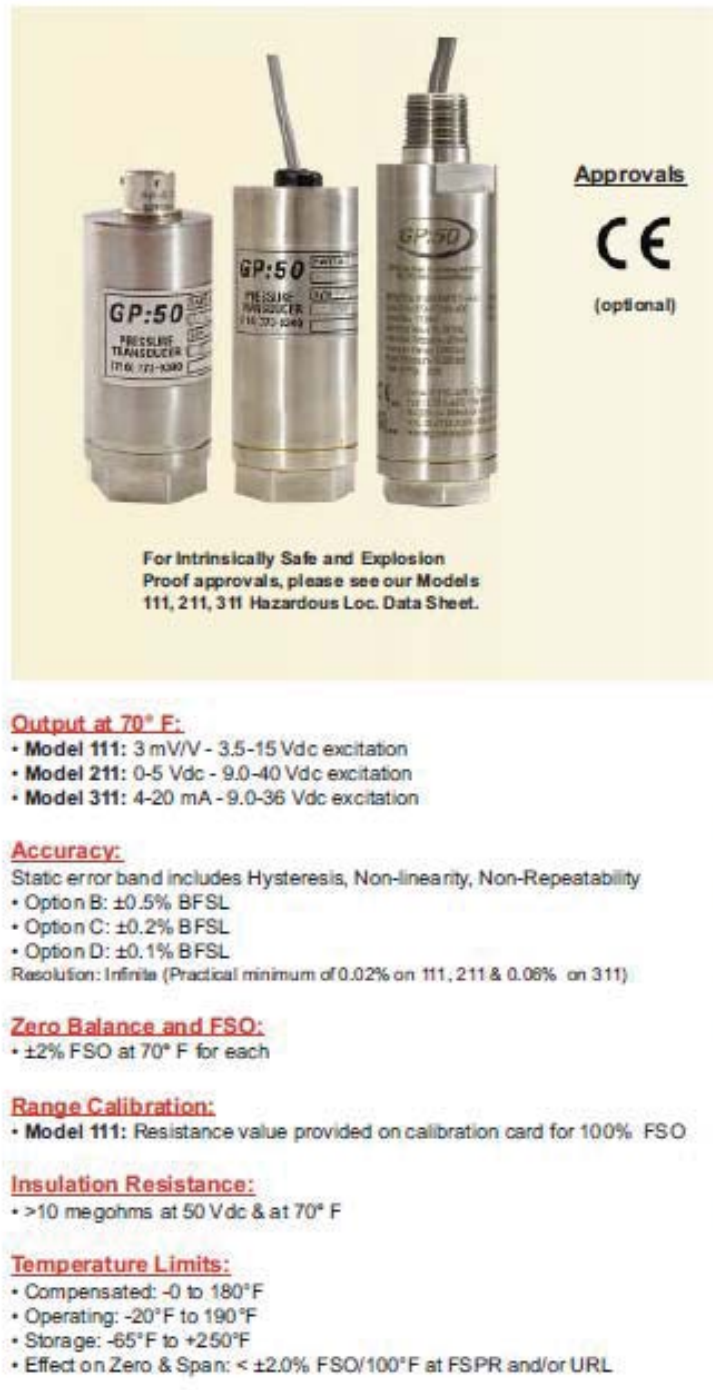

\section{FEATURES:}

- Rugged, welded, SST construction

- Strain gauge technology

- High accuracy, $\pm 0.5 \% \mathrm{FSO}$ standard, $\pm 0.1 \%$ FSO optional

- Resistant to pressure spike

- Small package size

PRESSURE RANGES:

$\cdot 0-5$ thru $0-20,000$ PSI

PSIG, PSIS, PSIA, PSIV \&

Compound ranges available.

\begin{tabular}{|c|c|c|c|}
\hline WIRING: & 111 & 211 & 311 \\
\hline $\begin{array}{l}\text { A/1 RED } \\
\text { B/2 GREEN }\end{array}$ & $\begin{array}{l}\text { EXC. } \\
\text { SIGGNAL }\end{array}$ & $\begin{array}{l}\text { EEXC, } \\
\text { +SIGNAL }\end{array}$ & $\begin{array}{l}\text { EEXCISIGNAL } \\
\text { NC }\end{array}$ \\
\hline C/3 WHITE & SIGNAL & & \\
\hline $\begin{array}{l}\text { D/4 BLACK } \\
\text { E/5 BLUE }\end{array}$ & EXC. & EXC,SIGNAL & $\begin{array}{l}\text { EXC/SIGNAL } \\
\text { NC OPT. GH }\end{array}$ \\
\hline $\begin{array}{l}\text { E/5 BLUE } \\
\text { FI6 BROWN }\end{array}$ & NC OPT. GH & $\begin{array}{l}\text { NCOPP. GH } \\
\text { NCOPT.GH }\end{array}$ & NC OPT. GH \\
\hline SHIELD & OPEN & OPEN & OPEN \\
\hline
\end{tabular}

Standard Connections:

- Process Connection: 1/4" NPT (F)

- Electrical Connection: 36" long Belden 8723, 24 AWG, 4 conductor cable (orequivalent)

Electricals:

- Input impedanoe: (Model 111) $350 \mathrm{ohm}$ nominal, full bridge

- Input Current (Model 211) 5mA nomina

- Laad Impedance:

(Model 111) 50,000 ohms min. for less than 0.1\% FSO attenuation. (Model 211) 2,000 ohms max. for less than $0.1 \%$ FSO attenuation. (Model 311) 1,350 ohms max. at 36 Vdc \& 750 ohms max. at 24 Vdc.

Mechanicals:

- Proof Pressure: 2 X FSPR (or URL) or 22,500 psi, whichever is less. - Burst pressure: Gauge/SG/Absolute - 5 X FSPR (or URL) or 23,000

Psi, whichever is less.
- Vacuum: 5 XFSPR in gauge

- Pressure Response: Less than $5 \mathrm{~ms} 10 \%$ to $90 \%$

- Weight $10 \mathrm{oz}$. nominal, options may increase weight

- Wetted Material: 316 \& 17-4 PH SST

- Enclosure Material: 316 SST

- Mounting: Pressure port

Uriess otharwise stated, thase specifcafions are the standards bo which the unts are

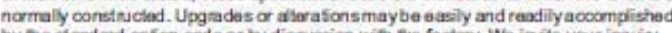
by the standard opfon code or by disoussion with the factory. We imilia your inquiry. without prior notification. Please contact the factory on all critical dimensions and specific ations for verification.

Figure C.14: Technical data sheet 1 of pressure transducer. 


\section{INDUSTRIAL GRADE PRESSURE TRANSDUCER Models 111, 211, 311}
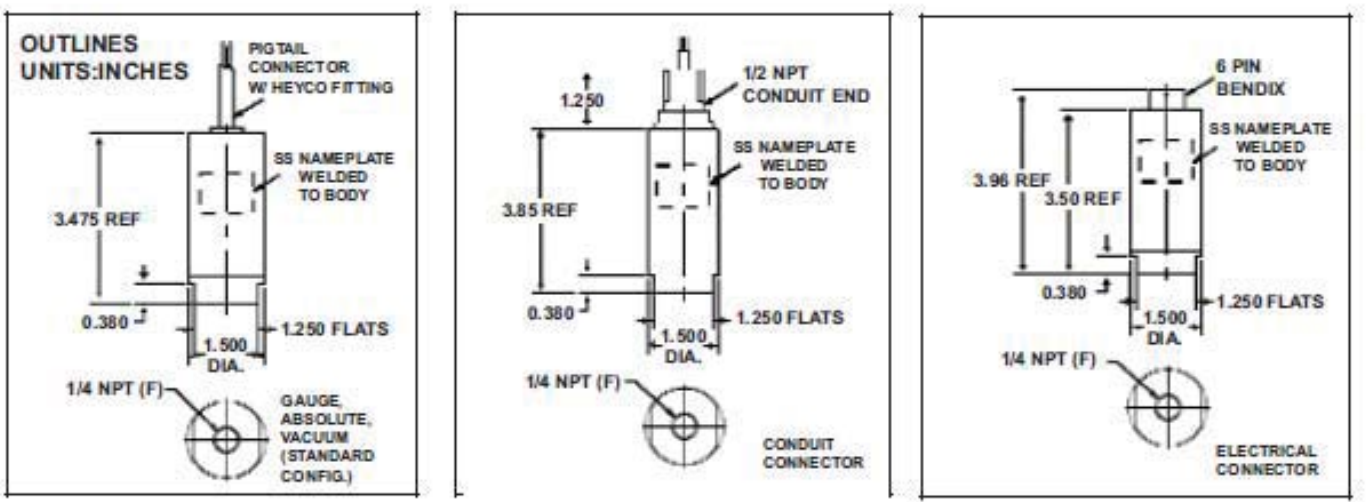

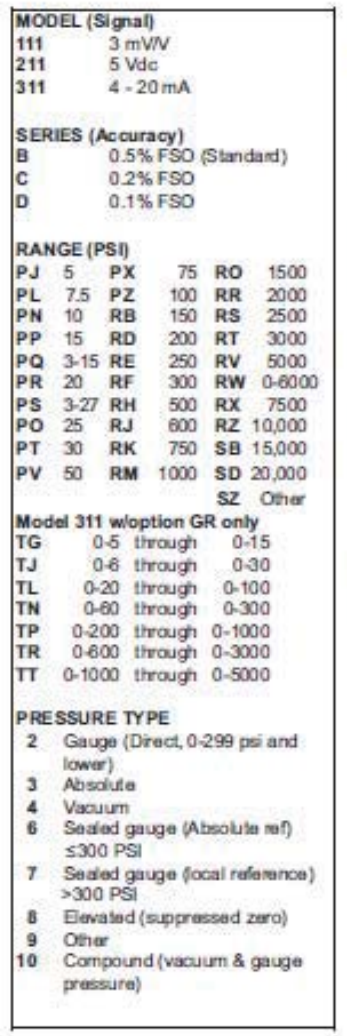

\begin{tabular}{|c|c|}
\hline & $\begin{array}{l}\text { NONS } \\
\text { CTRICAL CONMECTON }\end{array}$ \\
\hline AA & $36^{\circ} 22$ AWG Wiro losds wistain rolof \\
\hline CA & Bondx PTIH 106P \\
\hline $\mathrm{CB}$ & Bondx CF3 102E-14SEP \\
\hline$\varnothing$ & Bondx PCOZE-12aP \\
\hline $\mathrm{CD}$ & Comon WKo 325 \\
\hline$C E$ & Torminal Block \\
\hline CF & 1/2 NPT(M) throod with 36 losds \\
\hline CG & MS310zR 14 S $6 \mathrm{~S}$ \\
\hline $\mathrm{CH}$ & Vontod coblo, \& bng (NeMA4, sominstion) \\
\hline a) & DN 43650 (ncludes mato) \\
\hline cK & Lumborg RSF $312 \mathrm{~mm}$ \\
\hline a. & $1 / Z$ NPT (M) W/36' vantod Poly cablo (24AWG) \\
\hline $\mathrm{cm}$ & BondxPTils 84P, orequal \\
\hline CN & Bondx MS3torh 14S sP, arequal \\
\hline$\infty$ & M Junction Box (Indudas CF or Ca.) \\
\hline$C P$ & Cannon WK4-32S \\
\hline$\infty$ & Cannon WKA7-325 \\
\hline ct & 36 Totlon jpeket cablo (high tomp) \\
\hline cu & 1/2 NPT (A) conduit truosd wth 36 pgat \\
\hline$c z$ & Other \\
\hline$D E$ & P. 67 vertod Pay cablo (24AWG) \\
\hline DR & 4Pin min tast, 718-16 THD, Nokel Piad. \\
\hline & CESS COBSEC CNON \\
\hline AA & 1/4 NPT F (std port) \\
\hline FA & MS33649.4 (1/4 AN/10050, fomab) \\
\hline FC & 3E NPT (F) \\
\hline FD & $\operatorname{MS} 336564$ (7/16:20 UNF.3A) \\
\hline Fi & $1 / 8 \mathrm{NPT}(\mathrm{F})$ \\
\hline Fu & $1 / 4{ }^{-}$NPT (M) \\
\hline Fi. & $1 / 8 \mathrm{NPT}(\mathrm{M})$ \\
\hline FM & Ausodswo Type F $250-C, 9 / 16-18 / F)$ \\
\hline $\mathbf{P N}$ & $1 / 2$ NPT MO \\
\hline Fo & $1 / 4^{-}$BSpp $(\mathrm{M})$ \\
\hline LC & $1 / 4^{-}$VCR fting (fomalo nut) \\
\hline LG & SAE-4 (F)O-ring sod trood \\
\hline $\mathrm{HH}$ & SAE6 (M) Oding soal staght thesd (w/Oring) \\
\hline LP & $1,4^{*}$ BSPP (A \\
\hline LT & SAE 4 (M) O-ting sod staight throod (w/Oting) \\
\hline FE & Bulet nom for submers ble opton GM, $316 \mathrm{sS}$ \\
\hline L & Taporod iniet, sudgo level \\
\hline W & Ibperod niot w/ standatt plato \\
\hline$\overline{L x}$ & 1-1/2, woo szo Thi Clover fiting \\
\hline LYY & 2 thes szo Tti Clower itting \\
\hline & Other \\
\hline
\end{tabular}

\begin{tabular}{|c|c|}
\hline GEI & ERAL \\
\hline GA & Standardized oulpul to $10.5 \%$ FSO \\
\hline GB & Alernate fuli scala oulputs. Sat bo $12 \% 6$ FSO \\
\hline GC & Special calbrafion of a standand ranga fo. 5-10 point). \\
\hline GD & $\begin{array}{l}\text { Prassum overbad 10X rabed ranga, of } 22,5000 \text { pe. } \\
\text { whichever is less. Not avalialla with GM, CW, GY, GF, GP, }\end{array}$ \\
\hline & $\begin{array}{l}\text { HX, JP, GR. Burst prossume 15x rated range or } 23,000 \text { pei, } \\
\text { whichever is less. }\end{array}$ \\
\hline GE & Improved lamp comp to $10.5 \%$ FSOr100 $\mathrm{F}$ for zero \& span. \\
\hline GG & Airnath shurt cal (specily an SO) \\
\hline GH & $100 \% \pm 0.5 \%$ intams Shumt Cal \\
\hline GJ & Zaro \& span aqusts ( $\pm 10 \%$ FSO, 211 \& 311 anly) \\
\hline GK & Inoonal wethed parts \\
\hline GL & Oxygan carning. \\
\hline GM & 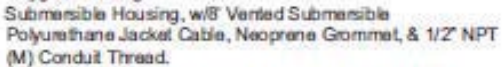 \\
\hline GR & $\begin{array}{l}\text { Meld rangasble opfion via Zero \& span adjust (311 anly. } \\
\text { indudes GJ, orty B accuracy, not w/GD) }\end{array}$ \\
\hline GS & 0-10Vde FSO, (Maded 211) (15 VDC Mn Exoitafon) \\
\hline GY & 316 SS prassuma cavity. (Opton GD not available) \\
\hline $\mathrm{HE}$ & $\pm 0.5 \%$ FSO zaro balanca (Sid, $W D^{*}$ accuracy), ranges 230 \\
\hline & psi ony \\
\hline HL & 36 Poly Casia NEMA-4X Rating \\
\hline $\begin{array}{l}\text { HL } \\
\text { HR }\end{array}$ & RFI prodaction. \\
\hline HR & ¿15 Vde awoitafion, (Modal 211) \\
\hline JE & 5000 ohm stain gavgas (Modal 111) \\
\hline as & Fast masponse (500 microsacond, Madel 211) \\
\hline JK & Barcmétic pressura, $23.35 \mathrm{Hga}$ \\
\hline is & Irternal dariping as specifad by custome. \\
\hline MA & $\begin{array}{l}\text { Valuge surga prolacton (ligiting mistanca) Modd } 311 \\
1.5 \text { Vde FSO }\end{array}$ \\
\hline cW & $\begin{array}{l}\text { Sutmersible housing w/1/2 NPT M \& } 8 \text { poly } 24 \text { ang } \\
\text { non-wontad cable (500 paimax) }\end{array}$ \\
\hline ME & $80 \%$ Shunt Cat \\
\hline Mx & EMIProlaction \\
\hline QU & Monal Watlad Parts \\
\hline & \\
\hline & \\
\hline & \\
\hline & \\
\hline
\end{tabular}

Figure C.15: Technical data sheet 2 of pressure transducer. 


\section{Appendix D}

\section{Thesis Files Summary}

This section contains the description of the files used in this thesis.

1. Table D.1 Data files(.xlsx)

2. Table D.2 Matlab codes (.m)

3. Table D.3 Matlab figures (.fig)

4. Table D.4 Documents

5. Table D.5 Visio and image files 
Table D.1

Data files (.xlsx)

\begin{tabular}{|c|c|c|}
\hline $\mathbf{S r} \#$ & File Name & Description \\
\hline 1 & Ricardo_engine_grey_box_data & Data file for Ricardo engine \\
\hline 2 & yanmar_engine & Data file for Yanmar engine \\
\hline 3 & plot data & $\begin{array}{l}\text { Final grey-box model results for Ricardo } \\
\text { engine }\end{array}$ \\
\hline 4 & gb_bberror & $\begin{array}{l}\text { Grey-box model vs black-box error for } \\
\text { Yanmar engine }\end{array}$ \\
\hline 5 & error_yanmar & $\begin{array}{l}\text { Error file for different nodes and epochs } \\
\text { for grey-box model for Yanmar engine }\end{array}$ \\
\hline 6 & incylinder_pressure_data & $\begin{array}{l}\text { Incylinder pressure transducer voltage } \\
\text { reading vs. crank angle }\end{array}$ \\
\hline
\end{tabular}


Table D.2

Matlab code (.m)

\begin{tabular}{|c|c|c|}
\hline Sr \# & File Name & Description \\
\hline 1 & PRF0_train_BB_ricardo & $\begin{array}{l}\text { Training code for black-box model for } \\
\text { PRF0 for Ricardo engine }\end{array}$ \\
\hline 2 & PRF20_train_BB_ricardo & $\begin{array}{l}\text { Training code for black-box model for } \\
\text { PRF20 for Ricardo engine }\end{array}$ \\
\hline 3 & PRF40_train_BB_ricardo & $\begin{array}{l}\text { Training code for black-box model for } \\
\text { PRF40 for Ricardo engine }\end{array}$ \\
\hline 4 & PRF0_valid_BB_ricardo & $\begin{array}{l}\text { Validation code for black-box model for } \\
\text { PRF0 for Ricardo engine }\end{array}$ \\
\hline 5 & PRF20_valid_BB_ricardo & $\begin{array}{l}\text { Validation code for black-box model for } \\
\text { PRF20 for Ricardo engine }\end{array}$ \\
\hline 6 & PRF40_valid_BB_ricardo & $\begin{array}{l}\text { Validation code for black-box model for } \\
\text { PRF40 for Ricardo engine }\end{array}$ \\
\hline 8 & PRF0_train_ricardo & $\begin{array}{l}\text { Training code for grey-box model for } \\
\text { PRF0 for Ricardo engine }\end{array}$ \\
\hline 9 & PRF20_train_ricardo & $\begin{array}{l}\text { Training code for grey-box model for } \\
\text { PRF20 for Ricardo engine }\end{array}$ \\
\hline 10 & PRF40_train_ricardo & $\begin{array}{l}\text { Training code for grey-box model for } \\
\text { PRF40 for Ricardo engine }\end{array}$ \\
\hline 11 & PRF0_valid_ricardo & $\begin{array}{l}\text { Validation code for grey-box model for } \\
\text { PRF0 for Ricardo engine }\end{array}$ \\
\hline 12 & PRF20_valid_ricardo & $\begin{array}{l}\text { Validation code for grey-box model for } \\
\text { PRF20 for Ricardo engine }\end{array}$ \\
\hline 13 & PRF40_valid_ricardo & $\begin{array}{l}\text { Validation code for grey-box model for } \\
\text { PRF40 for Ricardo engine }\end{array}$ \\
\hline 14 & yanmar_train_BB & $\begin{array}{l}\text { Training code for black-box model for } \\
\text { Yanmar engine }\end{array}$ \\
\hline 15 & yanmar_valid_BB & $\begin{array}{l}\text { Validation code for black-box model for } \\
\text { Yanmar engine }\end{array}$ \\
\hline 16 & yanmar_train_GB & $\begin{array}{l}\text { Training code for grey-box model for } \\
\text { Yanmar engine }\end{array}$ \\
\hline 17 & yanmar_valid_GB & $\begin{array}{l}\text { Validation code for grey-box model for } \\
\text { Yanmar engine }\end{array}$ \\
\hline 18 & datarange & Data range plot code \\
\hline
\end{tabular}


Table D.3

Matlab figures (.fig)

\begin{tabular}{|l|l|l|}
\hline Sr \# & File Name & Description \\
\hline 1 & incylinderpressurevoltage & Figure 2.15 \\
2 & Crankangle & Figure 2.19 \\
3 & Data_range_emissions_Ricardo_final & Figure 3.4 \\
4 & CO_final_ricardo & Figure 3.14 \\
5 & THC_final_ricardo & Figure 3.15 \\
6 & NOX_final_ricardo & Figure 3.16 \\
7 & CO_GB_yanmar & Figure 3.22 \\
8 & THC_GB_yanmar & Figure 3.23 \\
\hline
\end{tabular}


Table D.4

Data sheets

\begin{tabular}{|c|c|c|}
\hline Sr \# & File Name & Description \\
\hline 1 & vthakkar_latex.zip & Latex files for the thesis \\
\hline 2 & Vthakkar_Defense.ppt & Presentation file for defense \\
\hline 3 & encoder data sheet.pdf & $\begin{array}{l}\text { Techincal data sheet from } \\
\text { manufacturer for shaft encoder }\end{array}$ \\
\hline 4 & GP50 data sheet.pdf & $\begin{array}{l}\text { Techincal data sheet from } \\
\text { manufacturer for }\end{array}$ \\
\hline 5 & $\begin{array}{l}\text { Incylinder pressure sensor data } \\
\text { sheet.pdf }\end{array}$ & $\begin{array}{l}\text { Techincal data sheet from } \\
\text { manufacturer for incylinder } \\
\text { pressure sensor }\end{array}$ \\
\hline 6 & $\begin{array}{l}\text { Incylinder pressure sensor } \\
\text { calibration.pdf }\end{array}$ & $\begin{array}{l}\text { Calibration certificate from } \\
\text { manufacturer for incylinder } \\
\text { pressure sensor }\end{array}$ \\
\hline 7 & Lambda Sensor data sheet.pdf & $\begin{array}{l}\text { Techincal data sheet from } \\
\text { manufacturer for Lambda sensor }\end{array}$ \\
\hline 8 & Thermocouple data sheet.pdf & $\begin{array}{l}\text { Techincal data sheet from } \\
\text { manufacturer for thermocouple }\end{array}$ \\
\hline
\end{tabular}


Table D.5

Images and Visio drawing

\begin{tabular}{|c|c|c|}
\hline Sr \# & File Name & Description \\
\hline 1 & Thesis Structure & Figure 1.1 \\
\hline 2 & 3dLabsetup & Figure 2.1 \\
\hline 3 & flywheel & Figure 2.2 \\
\hline 4 & Engine front mount & Figure 2.3 (a) \\
\hline 5 & Rear mount & Figure 2.3(b) \\
\hline 6 & Modified water fuel panel & Figure 2.4(a) \\
\hline 7 & interface & Figure 2.4(b) \\
\hline 8 & Manufactured interface panel & Figure 2.5 \\
\hline 9 & coolant and water lines & Figure 2.6 \\
\hline 10 & ECU mount & Figure 2.7 \\
\hline 11 & intake air $23 d$ & Figure 2.8 \\
\hline 12 & intake air 3d & Figure 2.8 \\
\hline 13 & intakeairturboouttointercooler2 & Figure 2.9 \\
\hline 14 & Airheater & Figure 2.10 \\
\hline 15 & EGRTAP & Figure 2.11 \\
\hline 16 & EGRCOOLER2 & Figure 2.12 \\
\hline 17 & experimentalsetup1 & Figure 2.13 \\
\hline 18 & PnTintake & Figure 2.14 \\
\hline 19 & Encodermount3D2 & Figure 2.16 \\
\hline 20 & Encodermount3D3 & Figure 2.17 \\
\hline 21 & $\begin{array}{l}\text { Encodermount } 1 \quad \text { and } \\
\text { Encodermount } 2\end{array}$ & Figure 2.18 \\
\hline 22 & lamdasensor1 & Figure 2.20 \\
\hline 23 & OBDII wiring & Figure 2.21 \\
\hline 24 & $\begin{array}{l}\text { thermocouple } 1 \text {, thermocouple } 2 \text {, } \\
\text { and thermocouple } 3\end{array}$ & Figure 2.22 \\
\hline 25 & Final_engine1 & Figure 2.23 \\
\hline 26 & Final engine dyno setup & Figure 2.24 \\
\hline 27 & background HCCI control & Figure 3.1 \\
\hline 28 & GB_structure & Figure 3.5 \\
\hline 29 & ca50 & Figure 3.6 \\
\hline 30 & texh & Figure 3.7 \\
\hline 31 & emissions & Figure 3.8 \\
\hline
\end{tabular}




\section{Appendix E}

\section{Fair Use}

All the data sheets in Appendix C (Figures C.1- C.15) in the thesis are provided by the manufacturer. This information is used to compare the different products available in market and select the best option for the use. The data sheets in this thesis are attached for academic purpose and this will result in further use of the similar sensors and equipments from the same respective manufacturer thus improving sales. The purpose for the inclusion does not in any way effect the image of the company or the product. The purpose for the use is purely academic and non-profit. 